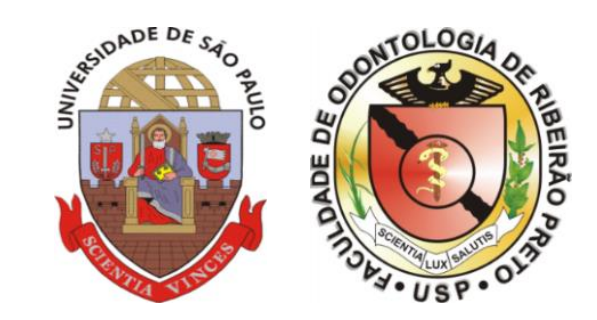

UNIVERSIDADE DE SÃO PAULO

FACULDADE DE ODONTOLOGIA DE RIBEIRÃO PRETO

CAROLINA NORONHA FERRAZ DE ARRUDA

CAPACIDADE DE REMOÇÃO DE BIOFILME E AÇÃO ANTIMICROBIANA DE SOLUÇÕES QUÍMICAS NA HIGIENIZAÇÃO DE PRÓTESES TOTAIS E ESCOVAS ESPECÍFICAS.

Ribeirão Preto 2018 


\section{CAPACIDADE DE REMOÇÃO DE BIOFILME E AÇÃO ANTIMICROBIANA DE SOLUÇÕES QUÍMICAS NA HIGIENIZAÇÃO DE PRÓTESES TOTAIS E ESCOVAS ESPECÍFICAS. \\ Versão corrigida}

Tese apresentada à Faculdade de Odontologia de Ribeirão Preto da Universidade de São Paulo, para obtenção do título de Doutor, junto ao Departamento de Materiais Dentários e Prótese.

Área de concentração: Reabilitação Oral

Orientadora: Profa. Dra. Helena de Freitas Oliveira Paranhos

\section{Ribeirão Preto}


AUTORIZO A REPRODUÇÃO E DIVULGAÇÃO DO TEOR TOTAL OU PARCIAL DESTE TRABALHO, POR QUALQUER MEIO CONVENCIONAL OU ELETRÔNICO, PARA FINS DE ESTUDO E PESQUISA, DESDE QUE CITADA A FONTE.

\section{FICHA CATALOGRÁFICA}

Elaborada pela Biblioteca Central do Campus USP - Ribeirão Preto

Versão corrigida da Tese. A versão original se encontra disponível na Unidade que aloja o Programa.

Arruda, Carolina Noronha Ferraz de

Capacidade de remoção de biofilme e ação antimicrobiana de soluções químicas na higienização de próteses totais e escovas específicas. Ribeirão Preto, 2018.

\section{3p.: il.; $30 \mathrm{~cm}$}

Tese de Doutorado apresentada à Faculdade de Odontologia de Ribeirão Preto/USP. Área de concentração: Reabilitação Oral.

Orientadora: Paranhos, Helena de Freitas Oliveira

1. Higienizadores de dentadura. 2. Prótese total. 3. Biofilmes.

4. Produtos com ação antimicrobiana. 


\section{FOLHA DE APROVAÇÃO}

\section{CAROLINA NORONHA FERRAZ DE ARRUDA}

Capacidade de remoção de biofilme e ação antimicrobiana de soluções químicas na higienização de próteses totais e escovas específicas.

Tese apresentada à Faculdade de Odontologia de Ribeirão Preto da Universidade de São Paulo, para obtenção do título de Doutor.

Área de concentração: Reabilitação Oral

Aprovado em:

\section{Banca Examinadora}

1) Prof.(a). Dr.(a).:

Instituição:

Julgamento: Assinatura:

2) Prof.(a). Dr.(a).:

Instituição:

Julgamento: Assinatura:

3) Prof.(a). Dr.(a).:

Instituição:

Julgamento: Assinatura: 



\section{Dedicatória}



A Deus por me proteger e me dar forças em todos os momentos, e permitir novos ensinamentos a cada dia.

Aos meus pais, Teresinha e Homero, meus exemplos de honestidade, sabedoria, carinho e amor. Sou grata pelo apoio e motivação para sempre seguir meus sonhos. Vocês me ensinam todos os dias o que há de mais importante na vida e me mostraram que com amor e dedicação, alcançamos grandes vitórias. Esta, é mais uma vitória nossa. Amo vocês!

Às minhas queridas irmãs, Marina e Júlia, pelo carinho, inspiração, afeto e experiências que compartifhamos e construímos todos os dias. Amo vocês!

À minha sobrinha, Clara, que me apresentou um amor totalmente diferente e imensurável. Eu amo você!

Ao meu cunhado, Leandro, pelo incentivo e exemplo de pesquisador. Obrigada por sempre ter tanto carinho e estar disposto a me ensinar e ajudar.

Ao meu namorado, Cristian, pelo companheirismo, carinho e amor. Obrigada por ser meu grande incentivador dentro e fora da vida acadêmica e Odontológica, e por compartilhar comigo tantos momentos. Amo você!

Aos meus avós, Crispim e Lourdes, Lúcio e Dalva, por sempre terem me mostrado a importância do conhecimento. Saudades!

À tia Lia pelos cuidados nos pequenos detalhes, que deram suporte aos meus dias. Obrigada por me mostrar que a vida tem sua beleza em diversas formas. Amo você!

A todos que torceram por mim e colaboraram com a realização desse tra6alho: meu eterno agradecimento! 



\section{Agradecimento Especial}



À Profa $\mathfrak{D r}^{a}$ Helena de Freitas Oliveira Paranhos, minha orientadora, por me apresentar à pesquisa e se dedicar ao meu desenvolvimento todos esses anos. Os ensinamentos e momentos que tive ao lado da senfora me proporcionaram crescimento e amadurecimento profissional e pessoal, que levarei em cada etapa da minha vida. Agradeço, acima de tudo, a confiança que depositou em mim em todos os nossos trabalhos juntas. Obrigada por cada detalhe nessa caminhada. Sou muito grata por tudo o que compartilhamos! Terá sempre o meu carinho e admiração.

"Mestre e discípulo se completam, se fazem mestre e discípulo. E o discípulo é o mestre do mestre, pois o ensina a ensinar. O mestre é o discípulo do discípulo, pois aprende a compreender e orientar. Mestre é mestre. Silêncio e precisão absolutos. Discípulo é discípulo. Dúvidas e questionamentos. Finalmente fundidos. Aonde quer que o discípulo vá, o mestre estará junto. Gratidão incomensurável. Um tanto do discípulo também fica impregnado no Mestre, que se transforma e se adapta a cada circunstância." Monja Coen. 



\section{Zgradecimentos}





\section{À Faculdade de Odontologia de Ribeirão Preto da Universidade de São}

Paulo, minha querida casa, pela oportunidade de tanto aprendizado e crescimento durante os cursos de Graduação, Mestrado e Doutorado. Sou privilegiada por ter por perto o melhor da Odontologia. Meu eterno agradecimento!

Ao Prof. Dr. Ricardo Faria Ribeiro, Coordenador do Programa de PósGraduação na área de Reabilitação Oral, por buscar não só a excelência do Programa, mas o crescimento individual dos pós-graduandos. O incentivo do senhor fez toda diferença. Muito obrigada por tudo.

À CARES (Coordenação de Aperfeiçoamento de Pessoal de Nivivel Superior), pela 6olsa de Doutorado fornecida.

À Profa ${ }^{a} r^{a}$ Cláudia Helena Lovato da Silva, por todo o conhecimento compartilhado e ajuda em todos os momentos. Muito obrigada pela doçura em cada gesto e palavra. A senhora é um exemplo para mim. Eu só tenho a agradecer pelos ensinamentos e convívio.

\section{À Profa Dr $^{a}$ Fernanda de Carvalho Panzeri Rires de Souza pelos} ensinamentos que tive desde a graduação até os dias de hoje. Obrigada por se dedicar e se importar com cada etapa do meu aprendizado, o que me proporcionou crescimento. Agradeço a confiança, as oportunidades e por manter as portas abertas por todos esses anos. A sua amizade é essencial na minha caminhada.

Ao Prof. Dr. Gilberto Orivaldo Chierice (Instituto de Química de São Carlos - USP) pelo fornecimento da solução à base de mamona (Ricinus communis) para a realização da pesquisa. 
Aos Professores do Departamento de Materiais Dentários e Prótese, da Faculdade de Odontologia de Ribeirão Preto da Universidade de São Paulo, pelos ensinamentos e contribuição. Não tenho palavras para expressar a minha gratidão pela oportunidade de aprender com vocês.

Às Funcionárias da Secretaria do Programa de Pós-Graduação em Reabilitação Oral da Faculdade de Odontologia de Ribeirão Preto da Universidade de São Paulo, Regiane de C. Tirado Damasceno, Fernanda Talita de Freitas e Denise Martins Fontes Gonçalves, por cada sorriso, paciência, atenção, carinho e amizade durante esses anos.

À Técnica do laboratório de Reabilitação Oral, da Faculdade de Odontologia de Ribeirão Preto da Vniversidade de São Paulo, Viviane de Cássia Oliveira, pela paciência, ensinamentos e principalmente pelo carinho e amizade. Muito obrigada por toda a ajuda, dedicação e zelo comigo e com os nossos trabalhos. Foi muito bom poder aprender e trabalhar com você. Eu só tenho a agradecer pelo nosso convívio e laços criados nesses anos!

À Técnica do Laboratório de Pesquisa de Metrologia Ana Paula Macedo, por toda ajuda, disponibilidade e paciência em cada trabalho durante todos esses anos. Obrigada por ter realizado mais uma estatística com dedicação. Agradeço sua atenção, carinho e amizade.

À minha querida amiga, Marcela Moreira Salles, pelo laço de afeto que criamos durante a pós-graduação. Obrigada por sempre estar disposta a me ajudar, ensinar e ouvir. O seu apoio, mesmo que de longe, é muito importante para mim! Muito obrigada pela amizade que formamos e regamos a cada dia! 
Aos meus amigos, Maurício Malheiros Badaró, Raniel Fermandes Peixoto, Marcela Moreira Salles, Marina Peris Vomero, Nathália Ramos da Silva, e Sergio Augusto de Freitas Vincenti e Bruna Honório Tonin pela amizade, companheirismo e afeto. Vocês tornaram essa caminhada mais leve e divertida, obrigada pelo apoio e parceria! Cada um de vocês estará sempre comigo em meu coração!!

Aos meus amigos e companheiros, Adriana B. Ribeiro, Tatiana $\mathbb{R}$. Cunha, Maria Paula Della Vecchia, Lourenço Roselino, Juliana B. Pinheiro, Danilo B. Sorgini, Flávia C. T. Coimbra, Millena M. Rocha, Renata C. Morais, muito obrigada por todos os momentos que passamos juntos, pelas palavras, risadas, conselhos, pelos momentos compartilhados. Só tenho a agradecer aos cuidados e afeto.

A todos os participantes da pesquisa, pelo empenho, carinfo, troca de ensinamentos e por me receberem sempre com um sorriso no rosto. Minha eterna gratidão.

Aos funcionários das clinicas, José Ap. Neves do Nascimento, Vera do Nascimento Scandelai, Silvia Helena Fabris F. Campos e Karina Dadalt Quaglio, que se mostraram sempre preocupados com a pesquisa e com os pacientes, foram prestativos e amáveis. O convívio com vocês deixou essa pesquisa mais fácil e leve. Muito obrigada!

A todos que participaram de forma direta ou indireta para que esse projeto se tornasse reafidade, meu terno e sincero agradecimento. 

Resumo 

ARRUDA, C. N. F. Capacidade de remoção de biofilme e ação antimicrobiana de soluções químicas na higienização de próteses totais e escovas específicas. 2018. 173p. Tese (Doutorado em Reabilitação Oral) - Faculdade de Odontologia de Ribeirão Preto, Universidade de São Paulo, Ribeirão Preto, 2018.

\section{RESUMO}

Este estudo clínico randomizado avaliou o efeito de soluções químicas, quanto à remoção de biofilme e ação antimicrobiana, na higienização das próteses totais superiores e escovas específicas. Quarenta e cinco participantes foram orientados a escovar suas próteses (escova específica para prótese e sabonete neutro) três vezes ao dia e imergí-las, uma vez ao dia, nas soluções: Grupo I- Solução salina (controle negativo); Grupo II- Hipoclorito de sódio 0,2\% (controle positivo); Grupo III- Peróxido Alcalino (Efferdent® Power Clean Crystals); Grupo IV- Ricinus communis a 6,25\%. Além disso, os participantes também foram randomizados para a imersão $(n=23)$ ou não imersão $(n=22)$ das escovas específicas nas soluções, juntamente às próteses, para avaliação das escovas quanto à ação antimicrobiana e degradação das cerdas. As avaliações foram realizadas antes (Baseline) e após os 7 dias de uso de cada solução. Para a remoção de biofilme, as próteses foram evidenciadas (vermelho neutro 1\%), fotografadas e a área de biofilme foi mensurada (Image Tool 3.00). A ação antimicrobiana foi avaliada por meio da contagem de Candida spp. e Streptococcus mutans. Para coleta do biofilme das próteses, as mesmas foram escovadas (escova Tek e solução salina) por 2 minutos, sendo a suspensão transferida para tubos de ensaio. As escovas foram preparadas, colocadas em meio de cultura Letheen Broth $(20 \mathrm{~mL})$ e levadas para cuba ultrassônica, seguido de agitação mecânica e centrifugação (6000 rpm, por 7 minutos). Diluições decimais $\left(10^{0}\right.$ até $\left.10^{-3}\right)$ com alíquotas $(50 \mu \mathrm{L})$ de cada diluição foram cultivadas em placas de Petri contendo meio de cultura adequado, para posterior incubação (aerobiose) por 48hs e contagem do número de colônias. As diferenças entre imersão ou não imersão da escova foram avaliadas pelo teste de MannWhitney $(\alpha=0,05)$. As propriedades de remoção de biofilme e ação antimicrobiana foram avaliadas pelo teste de Friedman, seguido pelo teste de Wilcoxon $(\alpha=0,05)$. Os resultados mostraram que, para a propriedade de remoção de biofilme, em ambos os grupos (com e sem imersão da escova), as soluções de hipoclorito de sódio a $0,2 \%$ [com imersão: posto-médio $(\mathrm{PM})=1,41$; sem imersão: $\mathrm{PM}=1,48]$, Efferdent ${ }^{\circledR}$ (com imersão: $\mathrm{PM}=2,41$; sem imersão: PM $=2,25$ ) e Ricinus communis a 6,25\% (com imersão: $\mathrm{PM}=2,48$; sem imersão: $\mathrm{PM}=2,77$ ) foram eficazes e semelhantes $(\mathrm{p}<0,001)$. Para as próteses, foi verificada ação antimicrobiana frente a Candida spp. para todas as soluções (hipoclorito de sódio a $0,2 \%$ : com imersão - PM=2,22,

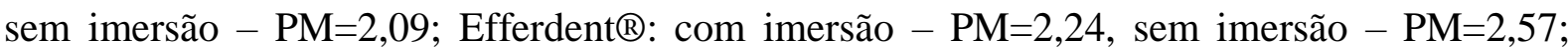


Ricinus communis a 6,25\%: com imersão - $\mathrm{PM}=2,20$, sem imersão - $\mathrm{PM}=2,75)$. Frente a $S$. mutans, as soluções de hipoclorito de sódio a 0,2\% (com imersão: PM=2,13, sem imersão: $\mathrm{PM}=1,96$ ) e Efferdent ${ }^{\circledR}$ (com imersão: $\mathrm{PM}=2,26$, sem imersão: $\mathrm{PM}=2,18$ ) foram as mais eficazes e a solução de Ricinus communis a 6,25\% (com imersão: PM=2,39, sem imersão: $\mathrm{PM}=2,75)$ apresentou valores intermediários $(\mathrm{p}<0,001)$. Não houve diferença significante na contagem UFC/mL de Candida spp. para as escovas, tanto para o grupo que não realizou a imersão das escovas $(p=0,108)$, como para os que realizaram o procedimento $(p=0,467)$. Para S. mutans, não houve diferença significante entre as soluções $(\mathrm{p}<0,001)$ para o grupo que não realizou a imersão das escovas, enquanto que para o grupo com imersão da escova o Efferdent e hipoclorito de sódio a $0,2 \%$ mostraram redução na contagem UFC/mL de $S$. mutans quando comparado ao grupo Controle ( $\mathrm{p}=0,001$ ). A solução de Ricinus communis a 6,25\% apresentou valores intermediários. As imagens em microscopia eletrônica mostraram grande deterioração das cerdas após 7 dias de uso, e a solução de hipoclorito de sódio promoveu um maior número de ranhuras nas cerdas quando imersas. Concluiu-se que todas as soluções foram efetivas na remoção do biofilme e frente a Candida spp., no entanto, frente a S. mutans, as soluções de hipoclorito de sódio a $0,2 \%$ e Efferdent ${ }^{\circledR}$ foram efetivas, enquanto a solução de Ricinus communis a 6,25\% promoveu ação intermediária. Em relação as escovas, não houve diferença entre os grupos em relação ao protocolo de imersão e na redução de UFC/mL de Candida spp. e $S$. mutans.

Palavras-chave: Higienizadores de dentadura. Prótese total. Biofilmes. Produtos com ação antimicrobiana. 


\section{Abstract}



ARRUDA, C. N. F. Ability of biofilm removal and antimicrobial action of chemical solutions in the hygiene of dentures and specific brushes. 2018. 173 p. Tese (Doutorado em Reabilitação Oral) - Faculdade de Odontologia de Ribeirão Preto, Universidade de São Paulo, Ribeirão Preto, 2018.

\begin{abstract}
This randomized clinical study evaluated the effect of chemical hygiene solutions on biofilm removal and antimicrobial action of denture and specific brushes. Forty-five participants were instructed to brush their dentures (specific brush and liquid soap) three times a day and to soak them, once a day, in the solutions: Group I- Saline solution (negative control); Group II Sodium hypochlorite $0.2 \%$ (positive control); Group III - Alkaline Peroxide (Efferdent ${ }^{\circledR}$ Power Clean Crystals); Group IV - Ricinus communis $6.25 \%$. In addition, the participants were also randomized to immersion $(n=23)$ or non-immersion $(n=22)$ of the specific brushes in the solutions, with the dentures, to evaluate the brushes for antimicrobial action and bristle degradation. Evaluations were performed before (Baseline) and after 7 days of use of each solution. For the biofilm removal, the dentures were disclosed ( $1 \%$ neutral red), photographed and the biofilm area was measured (Image Tool 3.00). The antimicrobial action was evaluated by counting Candida spp. and Streptococcus mutans. To collect denture biofilm, dentures were brushed (Tek brush and saline solution) for 2 minutes, and the suspension transferred to test tubes. The brushes were prepared and placed at Letheen Broth $(20 \mathrm{~mL})$ and taken to ultrasonic vessel, followed by mechanical shaking and centrifugation (6000 rpm for 7 minutes). Decimal dilutions $\left(10^{0}\right.$ to $\left.10^{-3}\right)$ with aliquots $(50 \mu \mathrm{L})$ of each dilution were grown in Petri dishes containing suitable culture medium, for further incubation (aerobiose) for $48 \mathrm{~h}$ and counting the number of colonies. The differences between brushes immersion or non-immersion by the Mann-Whitney test $(\alpha=0.05)$. The properties of biofilm removal and antimicrobial action were evaluated by Friedman test, followed by the Wilcoxon test $(\alpha=0.05)$. The results showed that, for the biofilm removal property, in both groups (brush immersion or non-immersion), $0.2 \%$ sodium hypochlorite [immersion: Mean-Rank $(M R)=1.41$; non-immersion: $M R=1.48$ ], Efferdent ${ }^{\circledR}$ (immersion: $M R=2.41$, non-immersion: $M R=2.25$ ) and $6.25 \%$ Ricinus communis (immersion: $M R=2.48$; non-immersion: $M R=2.77)$ were effective and similar $(\mathrm{p}<0.001)$. For dentures, was founded antimicrobial action against Candida spp. for all solutions $(0.2 \%$ sodium hypochlorite: immersion: $M R=2.22$, non-immersion: $M R=2.09$; Efferdent $®$ : immersion: $\mathrm{MR}=2.24$, non-immersion: $\mathrm{MR}=2.57 ; 6.25 \%$ Ricinus communis: immersion: $\mathrm{MR}=2.20$, nonimmersion: $\mathrm{MR}=2.75$ ). Against $S$. mutans, $0.2 \%$ sodium hypochlorite (immersion: $\mathrm{MR}=2.13$,
\end{abstract}


non-immersion $M R=1.96$ ) and Efferdent ${ }^{\circledR}$ (immersion: $M R=2.26$, non-immersion: $M R=2.18$ ) were the most effective and 6.25\% Ricinus communis (immersion: $\mathrm{MR}=2.39$, non-immersion: $\mathrm{MR}=2.75$ ) showed intermediate values. There was no significant difference in the brushes $\mathrm{CFU} / \mathrm{mL}$ of Candida spp. for group that did not perform brush immersion ( $\mathrm{p}=0.108$ ), as well as for those who performed the procedure $(\mathrm{p}=0.467)$. For $S$. mutans, there was no significant difference between the solutions $(\mathrm{p}<0.001)$ for the group that did not immerse the brushes, whereas for the brush-immersion group, Efferdent and $0.2 \%$ sodium hypochlorite showed a reduction in the UFC / $\mathrm{mL}$ count of $S$. mutans when compared to the Control group $(\mathrm{p}=0.001)$. $6.25 \%$ Ricinus communis presented intermediate values. The electron microscopy images showed a great deterioration of the bristles after 7 days of use, and the sodium hypochlorite solution promoted a greater number of grooves in the bristles. It was concluded that all solutions were effective for biofilm removal and Candida spp.. However, for S. mutans $0.2 \%$ sodium hypochlorite and Efferdent ${ }^{\circledR}$ were effective, whereas $6.25 \%$ Ricinus communis showed intermediate action. Regarding the brushes, there was no difference between the groups in relation to the immersion protocol and in the reduction of CFU/mL of Candida spp. and $S$. mutans.

Keywords: Denture cleansers. Denture. Biofilms. Products with antimicrobial action. 



\section{SUMÁRIO}

\section{RESUMO}

ABSTRACT

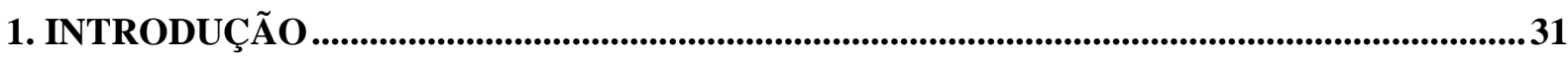

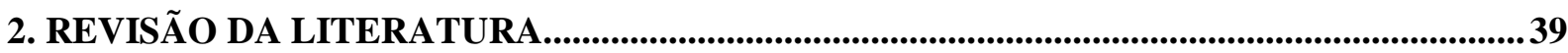

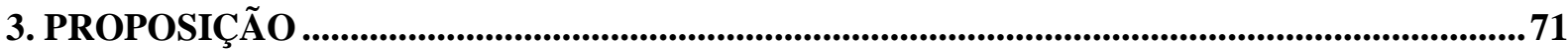

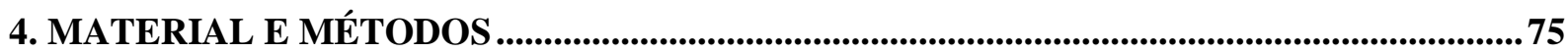

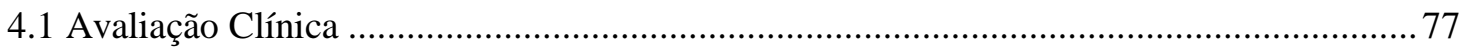

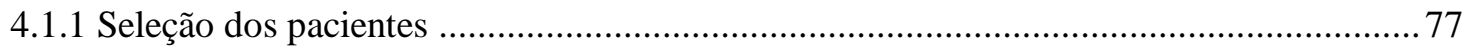

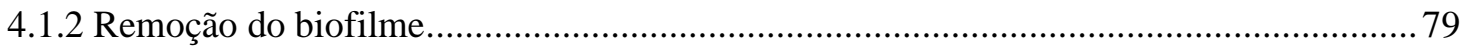

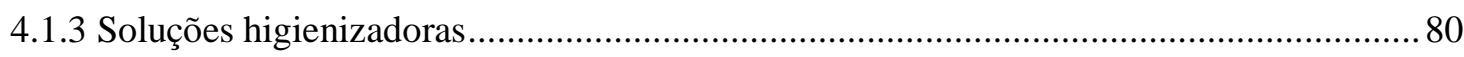

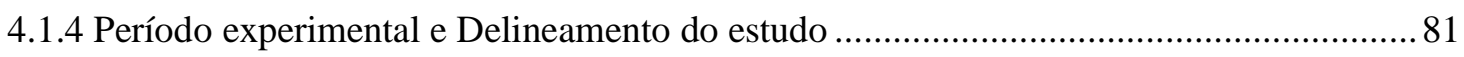

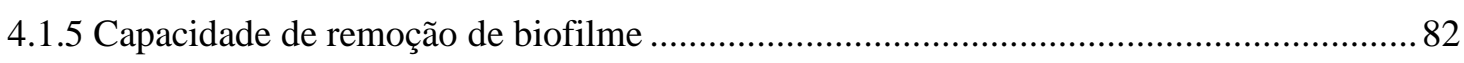

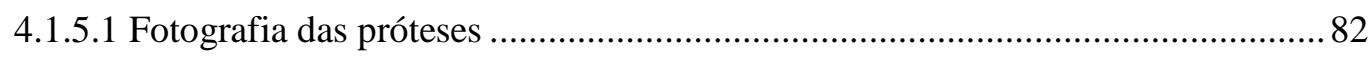

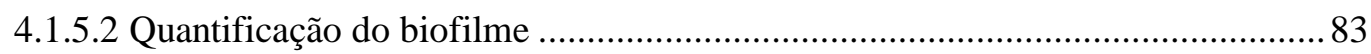

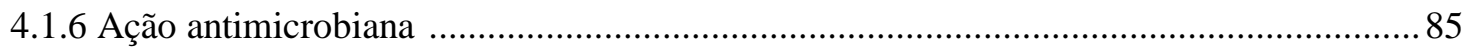

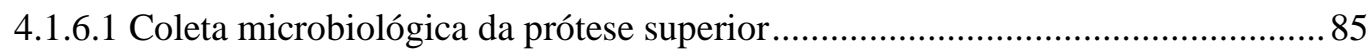

4.1.6.2 Coleta microbiológica da escova específica.........................................................8

4.1.7 Microscópio Eletrônico de Varredura (MEV) ………………........................................... 89

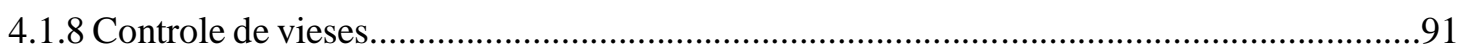

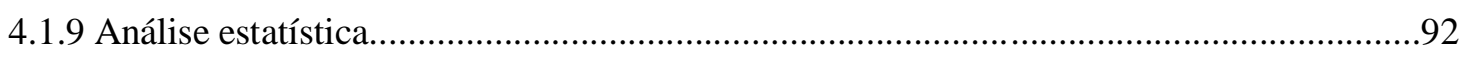

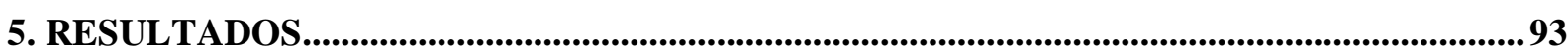

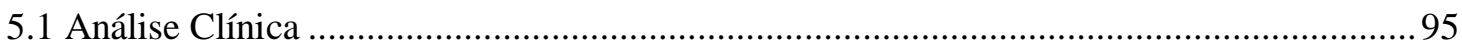

5.1.1 Capacidade de Remoção de Biofilme ..........................................................................96

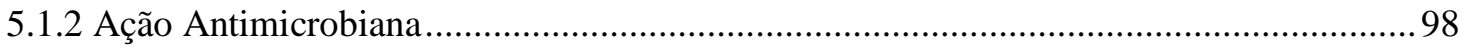

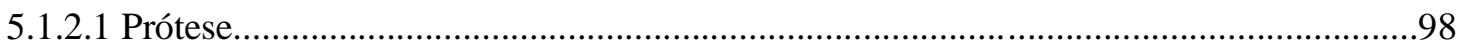

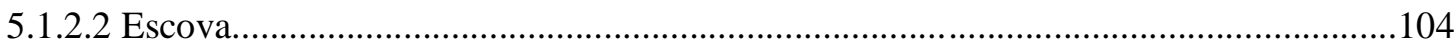

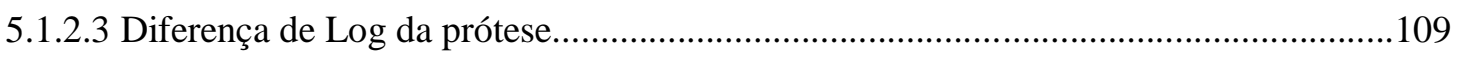

5.1.3 Microscopia Eletrônica de Varredura (MEV)............................................................110

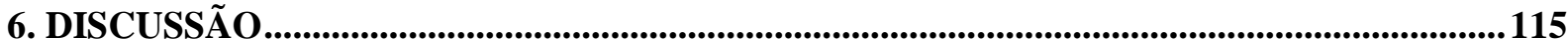

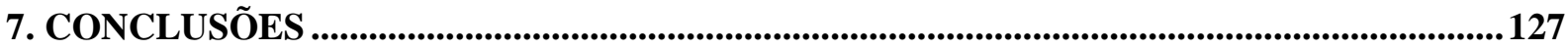

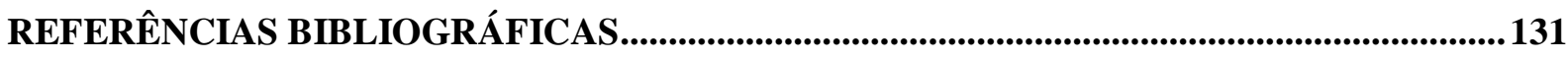

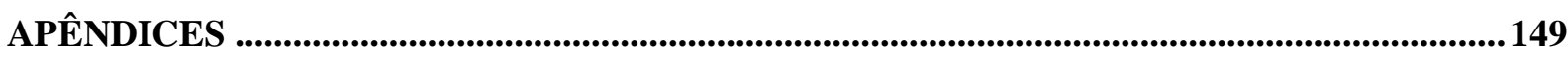

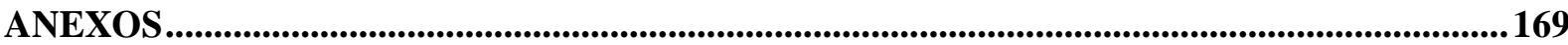



1. Introdução 

A prótese total pode atuar como um reservatório de micro-organismos patogênicos, quando ocorre a formação de biofilme em sua superfície. A presença desses micro-organismos, pode levar ao desenvolvimento de patologias locais e sistêmicas, como endocardite bacteriana, pneumonia por aspiração, infecção gastrointestinal e doença pulmonar obstrutiva crônica (Coulthwaite; Verran, 2007), uma vez que o contato das próteses totais com o tecido oral, saliva e sangue cria um meio de transferência de micro-organismos para outras áreas do corpo (De Paola; Minah; Elias, 1984; Powell et al., 1990).

O biofilme consiste em massa microbiana densa formada pela multiplicação e desenvolvimento de micro-organismos envoltos por uma matriz polimérica. Uma cadeia de processos consecutivos permite a sua formação, iniciando pela adesão das células planctônicas a uma superfície, seguido pela proliferação e acúmulo de células, e formando assim, a matriz extracelular (Azevedo; Cerca, 2012). Ao formarem o biofilme, esses micro-organismos ganham notória importância no contexto clínico, uma vez que se tornam mais resistentes aos agentes antimicrobianos (Zarnowski et al., 2014).

Dentre os micro-organismos presentes no biofilme da prótese total, os mais encontrados são fungos do gênero Candida spp. e bactérias como o Streptococcus mutans. A presença de Candida spp. está relacionada ao desenvolvimento da Estomatite Protética, sendo a Candida albicans a principal espécie envolvida na etiologia desta patologia (Nikawa; Hamada; Yamamoto, 1998; Gendreau; Loewy, 2011; O’Donnel et al., 2015). Já a espécie bacteriana S. mutans tem sido associada à presença de Candida spp., e, consequentemente, considerada de grande importância na formação e estabilização do biofilme, e também está relacionada ao desenvolvimento da Estomatite Protética (Campos et al., 2008; Chopde et al., 2012). Dessa forma, é importante que ocorra uma redução desses micro-organismos nas próteses totais dos pacientes.

Dentre os higienizadores de próteses totais, os agentes químicos de imersão têm sido indicados para o controle do biofilme de próteses totais, uma vez que auxiliam a redução e o controle dos micro-organismos presentes no biofilme. Estas soluções podem ser utilizadas por 8 horas, denominadas de imersões longas ou noturnas (“overnight”) (Kulak et al., 1997; Webb; Thomas; Whittle, 2005; Peracini et al., 2016, 2017), ou por 03 a 20 minutos, denominadas de imersões curtas (Pavarina et al., 2003; Barnabé et al., 2004; Boscato et al., 2009; Segundo et al., 2014; Andrade et al., 2014; Salles et al., 2015a,b; Badaró et al., 2016,2017; Arruda et al., 
2017). Podem ser empregados de forma isolada; no entanto, apresentam maior efetividade no controle do biofilme quando associadas a um método mecânico (Paranhos et al., 2007a,b).

Estudos sugerem que a adesão microbiana não ocorre apenas no epitélio oral e nas superfícies de aparelhos protéticos (Baena-Monroy et al., 2005; Azevedo; Cerca, 2012; DiBardino; Wunderink, 2015), mas também nas escovas utilizadas durante a higienização. Neste sentido, estudos têm demonstrado a importância da higienização de escovas utilizadas por pacientes dentados (Nascimento et al., 2012,2014; Nelson-Filho et al., 2014; Basman et al., 2016), uma vez que os micro-organismos podem permanecer viáveis nas cerdas das escovas entre um a 7 dias após a escovação (Efstratiou et al., 2007). A higienização das escovas tem o objetivo de promover a descontaminação e evitar a recontaminação do paciente por esses microorganismos (Erikson, 1997; Arai et al., 2003).

No entanto, estudos relacionados às escovas utilizadas por pacientes edêntulos são escassos, e devem ser desenvolvidos por ser um fator importante na eliminação ou diminuição de micro-organismos patogênicos entre os usuários de próteses totais. Além disso, torna-se importante verificar a topografia das escovas, uma vez que um maior desgaste das cerdas pode levar ao maior acúmulo de biofilme. A prevenção da colonização microbiana das cerdas das escovas após a escovação consiste em uma forma importante de controlar o crescimento e a proliferação dos micro-organismos e, assim, evitar as reações inflamatórias e as implicações clínicas que podem resultar da colonização dos tecidos bucais (Nascimento et al., 2014).

As soluções de hipoclorito de sódio são conhecidas pela efetividade na higienização de próteses totais (Jagger; Harrison, 1995; Nikawa et al., 1999; Shay, 2000; Barnabé et al., 2004; Felton et al., 2011; Porta et al., 2013; Salles et al., 2015a; Badaró et al., 2017; Arruda et al., 2017); porém, para serem consideradas seguras, fatores como concentração da solução, tempo de imersão e período de utilização, precisam ser considerados. Estudos clínicos randomizados mostraram efetividade do hipoclorito de sódio no controle do biofilme na concentração de $0,5 \%$ em imersões de 20 (Boscato et al., 2009; Salles et al., 2015a; Badaró et al., 2017) e 10 minutos (Lima et al., 2006). No entanto, apesar de efetiva, esta concentração, quando empregada em imersões de 8 horas por um período de 5 anos de uso, causou alterações de cor e resistência à flexão da resina acrílica (Peracini et al., 2017) e aumento da rugosidade de superfície após 18 meses de uso (Paranhos et al., 2013).

Desta forma, estudos com concentrações mais diluídas têm sido realizados. Neste sentido, Arruda et al. $(2017,2018)$ mostraram, por meio de estudo in vivo, que a concentração 
de $0,2 \%$ foi efetiva, quando utilizada em imersões curtas de 20 minutos, frente a remoção do biofilme e ação antimicrobiana frente a Candida spp.. Além disso, essa solução não causou efeitos adversos clinicamente significantes aos materiais constituintes das próteses, simulando 5 anos de uso (Arruda, et al., 2018; Rocha, 2018). Esses resultados mostram viabilidade do uso dessa solução, mostrando que ela é segura e pode ser utilizada como higienizador de próteses totais.

As soluções de peróxidos alcalinos são higienizadores químicos também amplamente indicados e empregados por usuários de próteses totais (Nikawa et al., 1999; Shay, 2000; Felton et al., 2011; Kumar et al., 2012; Ramage et al., 2012; Duyck et al., 2013; Lucena-Ferreira et al., 2014; Nishi et al., 2014; Coimbra et al., 2016; Peracini et al., 2016, 2017). Essas soluções tornaram-se populares não somente pela facilidade de uso, mas tambem pelo odor agradável, o que é uma vantagem em relação ao hipoclorito de sódio. Ao entrar em contato com a água tornam-se soluções alcalinas de peróxido de hidrogênio, e o oxigênio ativo liberado por essas soluções podem remover manchas e apresentar ação antimicrobiana (Council on Dental Materials, Instruments and Equipments, 1983). A maioria dos estudos realizados é in vitro e relacionada à ação antimicrobiana frente a micro-organismos específicos, sendo a Candida spp. o fungo mais estudado. Estudos que avaliam essas soluções quanto à capacidade de remoção do biofilme ou mesmo sobre biofilme in vivo não têm sido rotineiramente relatados.

A literatura mostra que, quando utilizados em períodos de imersões curtas, de 3 a 5 minutos, os peróxidos mostraram efetividade ou ação intermediária, frente a diversos microorganismos (Fernandes et al., 2011; Andrade et al., 2014; Coimbra et al., 2016). A literatura tem indicado que esses higienizadores são mais efetivos quando empregados em biofilmes recém formados (Keng; Lim, 1996; Gornitsky et al., 2002), em períodos longos de imersão (Rossato et al., 2011; Peracini et al., 2017) e associados a métodos mecânicos de higiene, como a escovação e o ultrassom (Hutchins \& Parker, 1973; Paranhos et al., 2007a,b, 2009; SilvaLovato et al., 2010; Nishi et al., 2014). No entanto, ao mesmo tempo que um maior período de imersão pode trazer maior efetividade na redução de micro-organismos, pode também causar alterações nos materiais constituintes das próteses, como alteração de cor (Peracini et al., 2017), rugosidade de superfície (Felipucci et al., 2011; Davi et al., 2012), interferindo assim, na durabilidade e sucesso da reabilitação protética.

Em estudo in vitro recente, Coimbra et al. (2016), encontraram efetividade do higienizador Efferdent frente a Candida glabrata, S. mutans, Enterococcus faecalis, 
Escherichia coli e Pseudomonas aeruginosa; no entanto, tal avaliação foi realizada com biofilme simples. Dessa forma, torna-se importante verificar a efetividade desse higienizador frente a micro-organismos de biofilme in vivo, avaliando não apenas sua ação antimicrobiana, mas também sua capacidede de reduzir a formação e manutenção do biofilme de próteses totais.

A planta Ricinus communis é produzida em vários países, da qual é possível extrair o óleo, que possui uma potente toxina proteica, o ricínio, que age especificamente inativando os ribossomos, promovendo a morte celular por inativação da síntese proteica (Pisani, 2009). Além disso, essa solução é bactericida devido à capacidade da quebra de moléculas de açúcar das paredes celulares de micro-organismos. A biocompatibilidade e atividade anti-inflamatória (Ferreira et al., 1999; Ito et al., 1999), bem como potencial bacteriostático e fungiostático incentivaram a realização de pesquisas na área odontológica, com o desenvolvimento de soluções irrigadoras em endodontia (Endoquil) e periodontia (Perioquil) (Siqueira, 2005) e como enxaguatório bucal para o tratamento da estomatite protética (Pinelli et al., 2013).

Os estudos dessa solução na higiene de próteses totais foram motivados pelo fato de apresentar potente ação detergente, ação antimicrobiana e não apresentar cor ou odor desagradáveis (Pisani, 2009; Pisani et al., 2010). Dessa forma, a solução de Ricinus communis tem sido avaliada, por meio de estudos clínicos e laboratoriais, como agente auxiliar na higienização de próteses (Pisani et al., 2010; Salles et al., 2015a,b; Badaró et al., 2016, 2017; Arruda et al., 2017), sendo que, apresentou ação antimicrobiana moderada quando utilizada nas concentrações de 10\% e 8\% (Salles et al., 2015a,b; Arruda et al., 2017). Uma concentração de $2 \%$ apresentou eficácia na remoção de biofilme de próteses totais superiores, na mesma intensidade que um peróxido, porém a ação antimicrobiana não foi avaliada (Andrade et al., 2014). Em um estudo piloto, Badaró (2017) verificou que a menor concentração da solução de Ricinus communis, necessária para inibir o crescimento de C. albicans e C. glabrata, foi a concentração de 6,25\%. Rocha (2018) verificou efetividade moderada, por meio de avaliação in vitro dessa concentração, frente a $C$. glabrata e $S$. mutans. No entanto, não foram realizados ensaios clínicos para verificar se tal concentração inibitória mínima é capaz de inibir o crescimento de micro-organismos em meio bucal, como fungos do gênero Candida spp.., tornando-se importante a realização de estudos clínicos randomizados a esse respeito.

A literatura evidencia que as soluções químicas podem ser benéficas para o controle do biofilme de próteses totais, quando associadas ao método mecânico de higiene, sendo a escovação o método principal. Neste sentido, torna-se importante a avaliação da topografia e 
contaminação microbiana das cerdas das escovas empregadas na higienização, pois podem constituir-se em fonte de contaminação, interferindo no protocolo de higiene. Além disso, estudos a respeito da capacidade de remoção do biofilme, ação antimicrobiana frente a microorganismos relevantes para a formação e estabilização do biofilme ainda são escasos. Desta forma, torna-se necessário o desenvolvimento de estudos clínicos randomizados envolvendo essas soluções, para que seja possível indicar um protocolo de higienização seguro, que favoreça a durabilidade do tratamento reabilitador e a saúde geral do paciente. 



\section{Revisão da Literatura}



A literatura relata que estudos têm sido desenvolvidos a respeito da ação antimicrobiana de higienizadores químicos de próteses totais. Em relação aos hipocloritos alcalinos e peróxidos alcalinos, experimentos laboratoriais (in vitro) e clínicos (in vivo) têm sido conduzidos; porém, os resultados ainda não são conclusivos. Em relação à solução de Ricinus communis, os estudos são escassos e, especificamente em relação ao controle do biofilme de próteses totais, tem abordado a propriedade de remoção de biofilme e a ação antimicrobiana. A revisão de literatura a seguir descreve estudos relacionados à efetividade no controle do biofilme de próteses dessas soluções.

Augsburger e Elahi (1982) compararam a eficácia de soluções à base de peróxido alcalino (Denalan, Efferdent: formulação nova e antiga, Polident e Kleenite: formulação nova e antiga) e um à base de hipoclorito alcalino (Mersene). Cento e dez usuários de próteses totais foram orientados a não higienizar as próteses, antes do uso dos tratamentos, por um período de 24 horas. Decorrido este período, os voluntários imergiram suas próteses (dez minutos) na solução correspondente ao grupo para o qual foram alocados. Para a quantificação do acúmulo de biofilme e manchas, as próteses foram divididas visualmente em quadrantes (quatro para a superfície vestibular e quatro para a superfície interna) que foram avaliados por escores, sendo: Escore 0: sem biofilme; Escore 1: biofilme leve ( 1 a $25 \%$ da área coberta com biofilme); Escore 2: biofilme moderado (26 a 50\% da área coberta com biofilme); Escore 3: muito biofilme (51 a 75\% da área coberta com biofilme); Escore 4: abundância de biofilme (76 a 100\% da área coberta com biofilme). Os resultados mostraram que um período de dez minutos não foi suficiente para uma remoção eficaz do biofilme e que, consequentemente, um período de imersão mais longo seria recomendado em conjunto com uma escovação mecânica. Dos agentes testados, o Mersene e o Kleenite foram os que obtiveram os melhores resultados, tanto para a remoção de manchas, como para a remoção de biofilme.

Moore, Smith e Kenny (1984) compararam a eficácia de oito higienizadores de próteses totais frente a micro-organismos aeróbicos, anaeróbicos e leveduras. Os produtos testados foram os peróxidos alcalinos (Denalan, Efferdent, Kleenite, Polident), os hipocloritos alcalinos (Clorox-Calgon e Mersene), um produto de origem desconhecida (Miller's) e a escovação com sabão Ivory. Na primeira parte do estudo, in vitro, os higienizadores do tipo imersão foram adicionados em tubos de ensaio contendo água esterilizada inoculada com Candida albicans. 
As concentrações testadas dos higienizadores foram: (1) recomendada pelo fabricante; (2) 1/2 da concentração e (3) 1/4 da concentração. Água destilada contendo o inóculo de Candida foi considerada o controle positivo, e água destilada, sem o inóculo, o controle negativo. Após 15, 30 e 60 minutos de imersão nas soluções, amostras foram coletadas, diluídas e semeadas em placas contendo Sabouraud Dextrose Agar. Os produtos Mersene, Clorox-Calgon e Miller's tiveram atividade fungicida semelhante, enquanto que Efferdent, Polident e Denalan foram menos efetivos. Na segunda parte do estudo, in vivo, foram selecionados doze pacientes, os quais foram instruídos a usar os higienizadores (Mersene, Polident, Efferdent, Miller's, Kleenite e Clorox-Calgon), a escovação com sabão Ivory e água de torneira. Os métodos químicos de imersão foram testados por 30 minutos e a escovação por 60 segundos; água destilada foi usada como controle por 30 minutos. Após os tratamentos, amostras foram colhidas, diluídas e semeadas em Sabouraud Dextrose Agar e Columbia Blood Agar. Após incubação e contagem das unidades formadoras de colônias, os resultados mostraram que o Miller's e Kleenite foram os agentes mais efetivos, seguidos da escovação (com água e sabão) e a imersão no agente Mersene. Embora o Clorox-Calgon tenha se mostrado efetivo na eliminação de leveduras em condições laboratoriais, ele não foi efetivo em condições clínicas.

Watkinson, McCreight e Wornock (1985) investigaram o efeito do hipoclorito alcalino como higienizador de prótese, quanto à prevalência de Candida albicans na cavidade oral de pacientes edêntulos com Estomatite Protética. Cinco participantes do estudo foram instruídos a remover suas próteses durante a noite e imergí-las em solução de hipoclorito alcalino (Dentural, McCarthys Ltd., Cheltenham, England) por duas semanas. Amostras microbianas foram colhidas do palato e da superfície da prótese antes e após o tratamento. Em três dos cinco pacientes, houve reincidência de Candida albicans. Segundo os autores, os resultados sugerem que o biofilme da prótese é constantemente recolonizado por leveduras da mucosa.

Basson, Quick e Thomas (1992) avaliaram a eficácia de produtos caseiros na limpeza de prótese. Foram confeccionadas placas acrílicas palatinas para 6 indivíduos dentados, as quais foram usadas durante o dia e imersas em soluções higienizadoras durante a noite. As soluções desinfetantes utilizadas foram: (1) Milton 4\% ( $\mathrm{NaOCl} 0,04 \%+\mathrm{NaCl} 0,66 \%)$; (2) Milton 1,2\% ( $\mathrm{NaOCl}$ 0,012\% + $\mathrm{NaCl}$ 0,19\%); (3) Vinagre não diluído; (4) vinagre 50\% (diluído); (5) sal $(\mathrm{NaCl}) 20 \%$; e (6) água de torneira (controle). Cada produto foi usado por 7 dias consecutivos e, posteriormente, as placas foram removidas, inspecionadas visualmente e realizou-se a contagem de bactérias viáveis. Todas as soluções testadas resultaram em uma significante 
redução do número de bactérias quando comparadas ao controle em água. As soluções com maior e menor efetividade foram a solução de Milton e o vinagre não diluído, respectivamente. A imersão noturna das placas em uma solução fraca de hipoclorito $(0,012 \%$ e $0,04 \%)$ resultou em significante redução do número de bactérias e de biofilme.

Nikawa et al. (1995a) avaliaram a atividade antifúngica de 11 higienizadores de próteses totais sobre o biofilme de Candida albicans, assim como avaliaram a compatibilidade desses higienizadores com condicionadores teciduais. Foram empregados 11 higienizadores (Denture Cleanser Tablets, Efterdent, 2-layered Efterdent, Kleenite, Pika, Double Action Polident, Polident for Partials, Super Strength Polident, Polident Powder, Smoker's Polident e Stain Away) e 6 condicionadores teciduais (Coe Comfort, Coe Soft, Fit Softer, GC Soft Liner, Hydrocast e Visoogel). Os resultados mostraram que todos os higienizadores reduziram a viabilidade fúngica, com melhores resultados para o Super Strength Polident. Todos os higienizadores também reduziram a atividade antifúngica, com melhores resultados para kleenite, Polident for Partials, Efferdent, Denture Cleanser Tablet e Super Strength Polident. Os autores concluíram que as alterações nos condicionadores teciduais variaram de acordo com o período de imersão, higienizador e condicionador empregados.

Nikawa et al. (1995b) avaliaram a eficácia de higienizadores de próteses na redução da atividade de $C$. albicans no biofilme. Onze higienizadores foram distribuídos em 5 grupos: 1) peróxidos alcalinos (Steradent), 2) peróxidos neutros com enzimas (Doctor Health, Dent Free, Nisodent, Polident e Liodent), 3) enzimas (Clean Soft, Pika e Plakick), 4) Drogas Cruas (Spa dent) e 5) Desinfetante (emuCAE). Todos os produtos foram usados segundo as recomendações dos fabricantes. Espécimes de resina acrílica $(50 \times 50 \times 0,7 \mathrm{~mm})$ (Bio Resin, Shofu) foram confeccionados de acordo com as instruções do fabricante, contaminados com suspensão de C.albicans e incubados a $37^{\circ} \mathrm{C}$ por 2 horas. Em seguida, $2 \mathrm{~mL}$ do meio de cultura Sabouraud foi colocado em cada poço com o corpo de prova contaminado e incubados por 144 horas a $37^{\circ} \mathrm{C}$. Após esse período, os espécimes foram imersos nas soluções higienizadoras por 2 horas, lavados com água destilada e em seguida, incubados em $2 \mathrm{~mL}$ de meio Sabouraud broth modificado. $\mathrm{O}$ pH de cada amostra foi determinado por um peagâmetro após 25 e 30 horas de incubação para avaliar a atividade residual do biofilme. Foram avaliados o efeito fungicida, a capacidade lítica de Candida e a habilidade de redução da atividade fúngica do biofilme. Além disso, os espécimes foram avaliados por meio de microscopia eletrônica de varredura (JMS6300). Os resultados mostraram que os peróxidos, os peróxidos neutros e os higienizadores 
Clean Soft, Pika e EmuCAE eliminaram completamente a levedura em 2 horas de incubação. Todos os higienizadores, exceto o Pika, não apresentaram ação lítica Candida significativa. $\mathrm{O}$ higienizador Dent Free apresentou a maior capacidade de redução da atividade fúngica do biofilme. A análise em microscopia mostrou que os peróxidos, os peróxidos neutros e o higienizador EmuCAE apresentaram a maior habilidade de remoção do biofilme de Candida e o higienizador Spa Dent (droga crua), a menor.

Kulak et al. (1997) investigaram o efeito da escovação e da imersão em agentes químicos, quanto à remoção dos contaminantes das superfícies das próteses totais (biofilme, cálculo e microbiota), por meio de microscopia eletrônica de varredura. Foram selecionados cinco pacientes, os quais tiveram as superfícies palatinas de suas próteses totais superiores seccionadas em oito amostras de $1 \mathrm{~cm}^{2}$. Tais amostras foram fotografadas (aumento 500x) para posterior leitura em microscópio eletrônico de varredura. Das oito amostras, uma não foi incluída nos procedimentos de higiene (controle). Seis amostras de cada prótese foram imersas durante o período noturno em soluções higienizadoras (Corega, Dentipur, Fittydent, hipoclorito de sódio a 5\%, Savlon e Ipanol) e uma das amostras foi submetida à escovação, por 30 segundos (escova de cerdas macias e pasta para dentaduras Ipana). Os resultados mostraram que a solução Savlon, quando empregada em imersão "overnight", apresentou maior efetividade em todos os procedimentos testados, enquanto o hipoclorito de sódio foi mais efetivo do que o Corega, Dentipur, Fittydent e Ipanol, na remoção dos depósitos de biofilme.

Webb et al. (1998) testaram, in vitro, a eficácia de dois métodos de higiene de próteses no controle de micro-organismos envolvidos com a Estomatite Protética: (1) irradiação por micro-ondas e (2) imersão em hipoclorito de sódio. Na primeira parte do experimento, vinte próteses totais superiores foram confeccionadas, sendo que dez foram contaminadas com Candida albicans e dez com Streptococcus gordonii. Dentro de cada grupo de microorganismos, 5 próteses foram irradiadas por micro-ondas e 5 ficaram como grupo controle. A análise microbiológica mostrou que as próteses inoculadas com os micro-organismos foram completamente desinfectadas após 6 minutos de irradiação, mas não removeu microorganismos não-viáveis da superfície das próteses. Os danos aos micro-organismos após irradiação de micro-ondas foram claramente visíveis por microscopia eletrônica de varredura. Na segunda parte do experimento, também vinte próteses foram confeccionadas, sendo metade inoculadas com C. albicans e metade com S.gordonii. Em cada grupo de micro-organismos, 5 próteses foram imersas durante 8 horas em hipoclorito de sódio a $0,02 \%$ ( $2 \mathrm{~mL}$ de hipoclorito 
de sódio/ $98 \mathrm{~mL}$ de água destilada) ou a 0,0125\% (1,25 mL de hipoclorito de sódio/ $98 \mathrm{~mL}$ de água destilada) e 5 próteses foram imersas em água destilada (controle). A análise microbiológica e a microscopia eletrônica de varredura mostraram que as próteses imersas por 8 horas em hipoclorito e inoculadas com C.albicans foram completamente desinfectadas, enquanto as que foram inoculadas com S.gordonii continuaram contaminadas. Os resultados indicaram que a irradiação por micro-ondas consiste em método mais eficaz que a imersão em hipoclorito na desinfecção de próteses. Contudo, diferentemente da irradiação por micro-ondas, o hipoclorito foi capaz de reduzir os níveis de micro-organismos não-viáveis residuais que ficaram aderidos à superfície das próteses.

Stewart et al. (2001) compararam a capacidade de desinfecção do hipoclorito alcalino e do clorossulfamato, bem como a eficácia desses agentes antimicrobianos em penetrar no biofilme bacteriano. Um meio de cultura inoculado com Pseudomonas aeruginosa e Klebsiella pneumoniae foi vertido durante 6 dias sobre espécimes de aço inoxidável, visando a formação de um biofilme artificial. Micro eletrodos foram utilizados para medir a concentração de cloro ativo no interior do biofilme, após a aplicação dos tratamentos. O efeito dos agentes sobre bactérias planctônicas, que estavam em suspensão numa solução aquosa, também foi avaliado. O clorossulfamato penetrou mais rapidamente no biofilme que o hipoclorito. O tempo de penetração médio do clorossulfamato em $1 \mathrm{~mm}$ de espessura de biofilme foi de 6 minutos, enquanto que para o hipoclorito foi de 48 minutos. As bactérias aderidas ao biofilme foram altamente resistentes à ação bactericida dos agentes antimicrobianos; já as bactérias planctônicas, que estavam em suspensão em solução aquosa, foram significativamente reduzidas após o uso dos agentes. Concluiu-se que a penetração dos agentes antimicrobianos no biofilme, provavelmente, está relacionada com a capacidade do antimicrobiano em reagir com os componentes orgânicos do biofilme; como o hipoclorito apresenta maior capacidade de reagir com os componentes orgânicos, ele demora mais tempo para penetrar no biofilme. Além disso, os autores sugerem que além da barreira física da matriz no biofilme, deve haver algum outro mecanismo de proteção das bactérias para que estas sejam resistentes à ação dos agentes antimicrobianos.

Garcia Junior (2002) avaliou a eficácia de hipoclorito de sódio 1\%, hipoclorito de sódio $2 \%$ e glutaraldeído 2\%, frente aos micro-organismos Staphylococcus aureus, Pseudomonas aeruginosa, Enterococcus faecalis, Streptococcus mutans e Candida albicans, na desinfecção da superfície externa e interna de uma resina acrílica termopolimerizável. Corpos de prova 
foram imersos nas soluções por 5, 10 e 15 minutos. Os resultados mostraram que 10 minutos de imersão foi adequado para a desinfecção da superfície externa da resina acrílica, sendo que a rugosidade não teve influência. A desinfecção por 15 minutos com hipoclorito de sódio $1 \% \mathrm{e}$ glutaraldeído $2 \%$ foram eficazes frente a maioria dos micro-organismos presentes internamente na resina acrílica.

Pavarina et al. (2003) avaliaram a efetividade de um protocolo de controle de infecção, limpeza e desinfecção de próteses removíveis. Trinta e dois pacientes, usuários de prótese total (superior e/ou inferior) e/ou prótese parcial removível (superior e/ou inferior) foram selecionados, sendo que um total de 64 próteses foram analisadas. Na primeira parte do estudo, culturas foram obtidas imediatamente após a retirada da prótese da cavidade oral do paciente; todas as próteses foram vigorosamente friccionadas com algodão estéril e posteriormente colocadas em meio de cultura de tioglicolato (Difco, Detroit, MI, USA) e imediatamente incubadas a $37+/-2^{0} \mathrm{C}$. Após $24 \mathrm{~h}$ a cultura foi observada para determinar a presença de crescimento microbiano. As culturas foram interpretadas por crescimento positivo (presença de turvação, formação de película e/ou formação de sedimento nos containers) ou crescimento negativo. Para eliminar material orgânico remanescente, as próteses foram escovadas por um minuto com solução de clorexidina a $4 \%$ e lavadas durante um minuto em água destilada esterilizada. As próteses foram separadas em quatro grupos, sendo imersas em $200 \mathrm{~mL}$ das seguintes soluções: (A) digluconato de clorexidina a 4\% (FGM Produtos Odontológicos, Joinvile, SC, Brasil), (B) Hipoclorito de Sódio a 1\% (Miyako do Brasil Ind. Com. Ltd, São Paulo, SP, Brasil), (C) Biocide (bactericida) a 0,48\% (Biotrol, International, Louisville, LA,USA) (D) Amosan (peróxido alcalino) a 3,78\% (Oral-B Irlanda Laboratórios, Kildare, Irlanda). Posteriormente, as próteses foram imersas em $200 \mathrm{~mL}$ de água esterilizada por 3 minutos, para eliminar qualquer resíduo de solução higienizadora. Todas as soluções foram associadas ou não ao uso do ultrassom, com o objetivo de avaliar se a presença do ultrassom melhora ou não a efetividade das soluções. Os resultados mostraram que gluconato de clorexidina a 4\%, hipoclorito de sódio a 1\% e solução de Amosan® a 3,78\% (peróxido alcalino) reduziram o crescimento de micro-organismos após os dez minutos de imersão; enquanto que o Biocide ${ }^{\circledR}$ não foi tão eficaz quando comparado às outras soluções. O uso do ultrassom não mostrou melhora evidente na eficácia das soluções de imersão avaliadas. Concluiu-se que o protocolo avaliado no estudo ("escovação" das próteses com clorexidina combinada com a 
imersão nas soluções - clorexidina a 4\%, hipoclorito a $1 \%$ e solução de Amosan) parece ser um método viável para prevenir contaminação cruzada entre os pacientes e odontólogos.

Harrison, Johnson e Douglas (2004) avaliaram o efeito de higienizadores de prótese na rugosidade superficial do material da base da prótese e a eficácia destes na remoção de Candida albicans. Foram confeccionados discos de resina acrílica termopolimerizável de $20 \mathrm{~mm}$ de diâmetro e $2 \mathrm{~mm}$ de espessura. Foram avaliados quatro produtos de limpeza: creme dental convencional; creme dental com removedor de manchas; pasta para limpeza de prótese e um higienizador do tipo imersão. Água foi usada como controle. As pastas e o higienizador do tipo imersão foram usados em diluições de 1:1, 1:2 e 1:3 com água, sendo que a escovação foi realizada utilizando uma escova dental, simulando um ano de limpeza. A rugosidade superficial dos discos foi medida, antes e após a limpeza, e então, foram inoculados com 1,2 x $10^{6}$ células de C. albicans. A eficácia dos higienizadores de prótese na remoção de C. albicans foi avaliada após um único evento de limpeza. O higienizador de imersão foi significativamente menos abrasivo do que as pastas. Não houve diferença significativa entre as diluições de qualquer produto de higienização utilizado. O higienizador do tipo imersão e as pastas removeram maioria de C. albicans dos discos, sendo que a limpeza apenas com água foi menos efetiva. Pode-se concluir que o higienizador do tipo imersão é o mais adequado devido a sua baixa abrasividade e eficácia na remoção de restos orgânicos.

Yilmaz et al. (2005) determinaram a ação antimicrobiana de quatro agentes químicos de higienização (Deconex, Savlex, hipoclorito de sódio a 2\% e hipoclorito de sódio a 5,25\%) sobre materiais reembasadores contaminados por diferentes espécies de micro-organismos (Staphylococcus aureus, Streptococcus sobrinus e Candida albicans). A ação antimicrobiana foi verificada por meio da contagem do número de células viáveis em solução salina, antes e após o uso dos agentes químicos. Espécimes dos materiais reembasadores, previamente esterilizados, foram imersos em meios de cultura líquido contaminados com os microorganismos. Após 48 horas de incubação, os micro-organismos em suspensão no meio de cultura líquido foram transferidos para soluções salinas, para que a contagem microbiana inicial fosse realizada; e os espécimes foram imersos nas soluções químicas testadas. Decorrido o tempo de 5 minutos de imersão, os espécimes foram inseridos em tubos de ensaio contendo solução salina e colocados em agitador mecânico para que os micro-organismos ficassem em suspensão na solução. A contagem microbiana final foi realizada após o processamento 
microbiológico. O hipoclorito de sódio a 5,25\% foi o método mais eficaz contra todos os microorganismos testados, seguido pelo hipoclorito de sódio a 2\%, Deconex e Savlex.

Lima et al. (2006) avaliaram, por meio de um estudo clínico crossover, o efeito de soluções higienizadoras de próteses totais sobre a rugosidade de superfície da resina acrílica e acúmulo de biofilme. Foram confeccionados aparelhos palatinos removíveis, os quais continham quatro espécimes de resina acrílica com valores de rugosidade inicial previamente conhecidos. Treze voluntários usaram os dispositivos durante três fases de quatro dias, adotando os seguintes tratamentos: T1: Controle (ausência de imersão em soluções higienizadoras); T2: Solução enzimática - imersão de 30 minutos; T3: Hipoclorito de sódio a 0,5\% - imersão por dez minutos. Para melhorar a formação de biofilme, o dispositivo foi imerso oito vezes/dia em solução de sucrose, para então, ser submetido ao procedimento desinfetante. A quantidade de biofilme formada nos corpos de prova foi verificada pela extração da quantidade de proteína presente e a mensuração final da rugosidade de superfície realizada. $\mathrm{O}$ estudo foi conduzido como um modelo cruzado com um período de 3 dias de wash out entre os momentos de utilização dos produtos. Os resultados demonstraram que o hipoclorito de sódio promoveu maior remoção do biofilme ao ser comparado aos demais grupos $(\mathrm{p}<0,01)$. Para rugosidade de superfície, o efeito dos tratamentos, tanto isoladamente, como levando em consideração o fator tempo, não foram estatisticamente significativos. Contudo, o efeito do tempo (baseline $\mathrm{x}$ análise final) foi significante $(\mathrm{p}<0,05)$ com aumento dos valores médios de rugosidade para todos os tratamentos. Os autores concluíram que a efetividade na remoção do biofilme depende da solução empregada e que a rugosidade da resina acrílica não é afetada pelos produtos utilizados.

Silva et al. (2008) avaliaram, in vitro, a eficácia de higienizadores de próteses (hipoclorito de sódio a $1 \%$, digluconato de clorexidina a $2 \%$, glutaraldeído a $2 \%$, vinagre a $100 \%$, pastilhas efervescentes à base de perborato de sódio e perborato de sódio a 3,8\%), na desinfecção de espécimes de resina acrílica contaminados por Candida albicans, Streptococcus mutans, Staphylococcus aureus, Escherichia coli e Bacillus subtilis, através da contagem das unidades formadoras de colônias (UFC). O grupo controle era constituído de espécimes contaminados que não haviam sido submetidos à desinfecção. Cada um dos 350 espécimes de resina foi transferido para um tubo de ensaio contendo meio de cultura e inoculado com a suspensão de um microorganismo. Após incubação, os espécimes foram imersos nas soluções higienizadoras por 10 minutos e, posteriormente, em solução salina para que as células ainda aderidas na resina se 
dispersassem na solução. Diluições decimais seriadas $\left(10^{0}\right.$ a $\left.10^{-3}\right)$ foram realizadas a partir dessas soluções resultantes e semeadas em placas de petri contendo meios de cultura específicos (Tripticsoy ou Sabouraud) e o número de unidades formadoras de colônias foi contado após o período de incubação. Os resultados mostraram que o hipoclorito de sódio a $1 \%$, a clorexidina a $2 \%$ e o glutaraldeído a $2 \%$ foram os métodos mais eficazes contra todos os micro-organismos testados, seguidos pelo vinagre a $100 \%$, o perborato de sódio a 3,8\% e as pastilhas efervescentes à base de perborato de sódio. Nenhuma diferença estatisticamente significante foi encontrada entre os espécimes contaminados com Candida sp. que foram tratados com as pastilhas efervescentes e os espécimes controle. O perborato de sódio foi mais eficaz que as pastilhas contra S.mutans, mas não reduziu significativamente o número destes micro-organismos quando comparado ao controle. Os autores concluíram que o hipoclorito de sódio a $1 \%$, o glutaraldeído a $2 \%$, a clorexidina a $2 \%$ e o perborato de sódio a 3,8\% consistem em alternativas válidas para a desinfecção da resina acrílica.

Boscato et al. (2009) avaliaram a influência de métodos de higiene oral na formação de biofilme sobre reembasadores resilientes de próteses totais. Vinte usuários de prótese total superior foram distribuídos aleatoriamente em dois grupos. G1: escovação de suas próteses com escova de cerdas macias e dentifrício (Colgate Tripla Ação); G2: o mesmo que G1 e imersão de suas próteses em hipoclorito de sódio a $0,5 \%$ por 20 minutos, uma vez por semana. Para que a formação do biofilme sobre o reembasador resiliente fosse avaliada, uma cavidade (10 x $10 \mathrm{x}$ $2 \mathrm{~mm}$ ) foi confeccionada na concavidade palatina de cada prótese e foi preenchida pelo reembasador. A evidenciação do biofilme (Vermelho neutro a 1\%) era realizada em quatro tempos: T0 (no momento em que o reembasador era colocado); T2 (após 2 semanas da colocação do reembasador); T4 (após 4 semanas) e T6 (após 6 semanas). As próteses com o biofilme evidenciado (vermelho neutro a 1\%) eram fotografadas e escores eram atribuídos ao biofilme por um dos pesquisadores. As fotografias foram projetadas em tela graduada vertical $(1 \mathrm{~m} \times 1 \mathrm{~m})$, para a seguinte classificação: Escore: 0 = ausência de biofilme; $1=$ leve (1-25\% da superfície coberta por biofilme); $2=$ moderado (26-50\% da superfície coberta por biofilme); 3 $=$ severo $(51-75 \%$ da superfície coberta por biofilme $) ; 4=$ muito severo (76-100\% da superfície coberta por biofilme). Os resultados mostraram que, independentemente do período de tempo, G1 $(0,65 \pm 0,52)$ apresentou os mais baixos valores de escore médio para a formação de biofilme no material reembasador; e que, quando o tempo foi analisado, independentemente do grupo, T6 $(1,3 \pm 1,08)$ apresentou os valores mais elevados de escore médio para a formação 
do biofilme que os demais tempos testados. Pode-se concluir que os métodos testados influenciaram na formação do biofilme em reembasadores resilientes.

Montagner et al. (2009) estudaram a ação antifúngica de diferentes agentes de limpeza sobre espécimes de resina acrílica (Vipi Wave) polimerizadas por micro-ondas, sem polimento e previamente inoculados com Candida albicans. Sessenta espécimes (10x10x5mm) foram inoculados com a cepa de C. albicans e incubados por 3 horas a $37^{\circ} \mathrm{C}$. Os espécimes foram distribuídos em 05 grupos experimentais e dois grupos controles: G1: clorexidina a 2,0\% (10 minutos); G2: hipoclorito de sódio a 0,5\% (10 minutos); G3: hipoclorito de sódio modificado (hipoclorito de sódio $0,5 \%$ e álcool $96^{\circ} \mathrm{GL}$ - 10 minutos); G4: peróxido alcalino Corega Tabs (5 minutos); G5: peróxido de hidrogênio 10v (30 minutos); C1: controle inoculado com $C$. albicans e imerso em solução salina (10 minutos) e C2: espécimes controle com ausência de inoculação, imerso em solução salina (10 minutos). Em seguida, cada espécime foi lavado com salina e transferida para tubos de ensaio contendo $5 \mathrm{~mL}$ de BHI broth e neutralizadores e incubados por 24 horas. Após esse período os tubos foram avaliados por meio de um espectrofotômetro. Alíquotas de cada tubo foram coletadas, inoculada em meio Sabourud Agar e incubadas a $37^{\circ} \mathrm{C}$ por 24 horas, para verificar o crescimento microbiano. Os resultados mostraram que somente o hipoclorito de sódio e o peróxido de hidrogênio a $10 \%$ apresentaram ação antifúngica contra $C$. albicans. O Corega Tabs, usado de acordo com as recomendações do fabricante, não foi eficaz na remoção da C.albicans. A solução de clorexidina a $2 \%$ não inibiu o crescimento dos micro-organismos mesmo após 10 minutos de imersão. Os autores concluíram que o hipoclorito de sódio e o peróxido de hidrogênio são mais eficientes frente à C.albicans do que a solução de clorexidina a $2 \%$ e agentes efervescentes.

Paranhos et al. (2009) realizaram um estudo com objetivo de comparar a eficácia de três métodos de higienização de próteses totais (químico, mecânico e associado) e os efeitos sobre diferentes micro-organismos presentes em biofilmes formados em superfície de resina acrílica termicamente ativada. Foram confeccionados 220 corpos de prova $(15 \mathrm{~mm}$ diâmetro e $4 \mathrm{~mm}$ de largura) de resina acrílica (Vipi Dental Ltda) a partir de um padrão de cera. As amostras foram esterilizadas com gás de óxido de etileno para posterior contaminação com inóculo microbiano com $10^{6} \mathrm{UFC} / \mathrm{mL}$. A contaminação foi realizada a $37^{\circ} \mathrm{C}$ durante $48 \mathrm{~h}$, para as espécies: cepas padrão (Staphylococcus aureus, Streptococcus mutans, Escherichia coli, Candida albicans, Pseudomonas aeruginosa, Enterococcus faecalis) e cepas de campo (S. mutans, C. albicans, Candida glabrata e Candida tropicalis). Após a incubação e contaminação, as amostras foram 
aleatoriamente distribuídas nos seguintes grupos: 1) Método químico: imersão em container com $200 \mathrm{~mL}$ de água destilada a $37^{\circ} \mathrm{C}$ e um tablete efervescente de peróxido alcalino (Bonyplus Tablets) durante 5 minutos; 2) Método mecânico: escovação com escovas dentais de cerdas macias (TEK - Johnson \& Johnson) e dentifrício para dentadura (Dentu Creme) por 20 segundos, e posterior imersão em água destilada durante 5 minutos; 3) Método associado: higienização pelo método mecânico e, em seguida, pelo método químico; 4) Controle Negativo: sem contaminação e posterior imersão em água destilada e esterilizada $(200,0 \mathrm{ml})$ durante 5 minutos e 5) Controle positivo: contaminação e posterior imersão em água destilada e esterilizada (200,0 ml) durante 5 minutos. Os resultaram mostraram que não houve diferença significativa entre os métodos para as cepas de S. mutans (padrão e experimental), S. aureus e P. aeruginosa. Já para E. faecalis, C. albicans (padrão e experimental) e C. glabrata houve efetividade dos métodos mecânico e combinado. Para E. coli e C. tropicalis, a combinação dos métodos foi mais eficaz que o método mecânico. O método combinado apresentou resultados semelhantes ao método mecânico e foi mais efetivo que o químico na maioria das espécies avaliadas (Enterococcus faecalis, Escherichia coli, Candida albicans (padrão e campo), Candida glabrata e Candida tropicallis). Com base nos resultados, os autores concluíram que a eficácia de cada um dos métodos de higienização testados depende do tipo de biofilme microbiano formado.

Jose et al. (2010) investigaram a capacidade de quatro higienizadores de prótese em descontaminar e esterilizar superfícies cobertas por biofilme de Candida albicans. Dezesseis cepas de $C$. albicans foram isoladas de pacientes com estomatite e uma cepa padrão (ATCC 90028) foram armazenadas em ágar dextrose Sabouraud a $4^{\circ} \mathrm{C}$. Uma colônia foi inoculada em $10 \mathrm{~mL}$ de meio específico e cultivada em placas de 96 poços durante toda a noite $\left(30^{\circ} \mathrm{C}\right)$ sob agitação em estufa bacteriológica. Em seguida, foram imersas nos higienizadores de prótese: Boots Smile (peróxido alcalino - 15 minutos), Medical Interporous (peróxido alcalino - 15 minutos), Steradent Active Plus (peróxido alcalino - 10 minutos) e Dentural (hipoclorito de sódio a 1,5\% - 20 minutos), seguindo as instruções do fabricante ou por 18 horas (overnight). Foram quantificadas a atividade metabólica do biofilme e a biomassa do biofilme. A MEV foi empregada para exame do biofilme. Os resultados foram obtidos pelo teste de XTT e análise de microscopia eletrônica de varredura. O higienizador Dentural foi o mais eficaz, reduzindo a biomassa em mais de $90 \%$ após 20 minutos. O Steradent Active plus foi significativamente mais eficaz em 10 minutos do que na imersão overnight. Todos os higienizadores reduziram a 
atividade metabólica em mais de $80 \%$ após a imersão durante a noite. O Boots Smile reduziu a atividade metabólica em apenas 15 minutos de imersão. O MEV revelou presença C. albicans após o tratamento com higienizador Dentural. O higienizador Medical Interporous TM promoveu redução de $80 \%$ a $75 \%$ após 15 minutos e 18 horas, respectivamente. Os autores concluíram que os higienizadores de prótese são efetivos contra C. albicans, tanto em termos de remoção, como de desinfecção; no entanto, a retenção de biofilme residual que poderia conduzir à recolonização foi observada. Os higienizadores de prótese usados foram capazes de reduzir o biofilme de $C$. albicans in vitro; no entanto, nenhum dos produtos testados foi eficaz na eliminação total de biofilmes de $C$. albicans. Segundo os autores, os métodos mecânicos alternativos são necessários para melhorar a remoção do biofilme.

Srinivasan e Gulabani (2010) avaliaram a eficácia de um protocolo de limpeza para usuários de prótese simples, que utiliza um higienizador comumente recomendado e disponível comercialmente (Corega,GlaxoSmithKline, Waterford, Ireland), combinando-o com bochecho com solução de digluconato de clorexidina a 0,2\% (Corsodyl, GlaxoSmithKline Consumer Healthcare, Brentford, UK). O estudo avaliou quantitativamente os números colônias microbianas cultivadas a partir das superfícies das próteses antes e após o uso do protocolo proposto e o recomendou como um protocolo padrão. Um grupo de 24 pacientes (16 homens, 8 mulheres, idade média: 65,9 anos) não-fumantes, usuários de prótese total participaram deste estudo clínico. Pacientes com prótese parcial ou usuário apenas de prótese superior ou inferior foram excluídos do estudo. Com o auxílio de cotonetes foram coletados a partir da superfície das próteses de cada um dos indivíduos, três amostras (I, II, e III), em diferentes períodos durante o estudo. Os 2 grupos receberam orientações para utilizar somente água na higienização das próteses, durante uma semana (período de washout), antes do início do estudo e no segundo período de washout, durante o estudo, antes do crossover. O grupo-1 foi submetido somente ao higienizador de prótese (Corega, GlaxoSmithKline, Waterford, Ireland) - 1 tablete por noite para as 2 próteses - (protocolo I), enquanto o grupo-2 foi submetido a bochecho com digluconato de clorexidina a $0.2 \%$ (Corsodyl, GlaxoSmithKline Consumer Healthcare, Brentford, UK) - $10 \mathrm{ml}$ por 1 minuto, 2x/dia, em complemento ao higienizador de prótese (protocolo II), durante a primeira semana (7 dias). Esperou-se uma semana (período de washout), durante a qual, utilizou-se apenas água por ambos os grupos (7 dias). Então, uma troca foi realizada, o Grupo-1 foi instruído a usar o protocolo II, enquanto o grupo2 foi instruído a descontinuar o protocolo II e prosseguir com o protocolo-I durante uma 
semana ( 7 dias). $O$ estudo teve duração total de 21 dias. Em seguida, foi obtido um terceiro conjunto de amostras. As unidades formadoras de colônias foram analisadas estatisticamente para cada paciente e para cada amostra. Os resultados mostraram que houve uma redução significativa no número de bactérias e uma diferença estatisticamente significativa após a administração dos protocolos em ambos os grupos $(\mathrm{P}<0.001)$. Entretanto, houve pouca significância na comparação das amostras entre os grupos $(\mathrm{P}=0.026)$ no período do estudo inicial, e a comparação dos grupos, após o cruzamento $(\mathrm{P}=$ 0.140), não foi estatisticamente significativa. Os autores concluíram que o uso do higienizador de prótese definitivamente reduziu o número de micro-organismos em comparação com métodos manuais simples de limpeza de próteses totais. Embora tenha havido uma diminuição substancial nas colônias bacterianas após o uso do enxaguatório bucal, esta não foi estatisticamente significante.

Iseri; Uludamar; Ozkan (2011) avaliaram a eficácia de diferentes agentes de limpeza na adesão de Candida albicans à resina acrílica. Culturas de C. albicans foram inoculadas em 2 $\mathrm{mL}$ de Agar Dextrose Sabouraud (SDA) e incubadas a $37^{\circ} \mathrm{C}$ por 24 horas. Em seguida, foram centrifugadas por 10 minutos (3000 rpm), lavadas em PBS, e diluídas para obtenção de uma suspensão de $10^{6}$ células de C. albicans/mL.Os 180 espécimes de resina acrílica (10x10x2mm) foram contaminados com a suspensão, incubados a $37^{\circ} \mathrm{C}$ durante 90 minutos e distribuídos nos grupos $(\mathrm{n}=30)$ : Polident (peróxido alcalino), Efferdent (peróxido alcalino), Fittydent (peróxido alcalino), CloSYSII (Dióxido de Cloro) e Corsodyl (Gluconato de Clorexidina 0,2\% ). Os corpos de prova foram imersos em $40 \mathrm{~mL}$ de cada higienizador a $37^{\circ} \mathrm{C}$ durante $15,30 \mathrm{e}$ 60 minutos. As células fúngicas aderidas a superfícies de resina acrílica foram fixados em formaldeído e contadas por meio de um microscópico óptico. Os resultados mostraram que as soluções CloSYS e Corsodyl foram mais eficazes na remoção de C. albicans para todos os tempos de tratamento. Todos os peróxidos alcalinos reduziram o número de colônias de $C$. albicans, mas nenhum conseguiu eliminá-la completamente. A redução significativa do número de $C$. albicans no presente estudo sugere que o uso de enxaguatórios bucais pode ser um método adequado para a limpeza de próteses.

Lee et al. (2011) avaliaram a eficiência de seis métodos de limpeza de prótese diferentes para remoção de Candida albicans. Foram confeccionados 140 espécimes (40 x 12 × 3 mm) de resina acrílica (Lucitone 199) de acordo com as instruções do fabricante e esterilizados com óxido de etileno. Cada espécime foi colocado em tubos de ensaio com $6 \mathrm{~mL}$ de suspensão de 
C. albicans (6-7 x $107 \mathrm{cfu} / \mathrm{mL})$ e incubado por $2 \mathrm{~h}$ a $37^{\circ} \mathrm{C}$. Após a contaminação os espécimes foram higienizados de acordo com os métodos $(n=20)$ : 1) escovação com escova macia (Colgate Extra Clean) e enxague em água destilada; 2) Imersão em Polident (Peróxido alcalino - 15 minutos); 3) Associação método 2 com 1; 4) Imersão em Gluconato de Clorexidina 0,12\% (Parmason Shining - 15 minutos); 5) Irradiação de UV (ADH Health Products - 10 minutos); 6) Imersão em água destilada esterelizada (15 minutos) e 7) Controle (sem tratamento).Em seguida, foram lavados e colocados em $1 \mathrm{~mL}$ de Sabouraud dextrose broth por 10 minutos e posteriormente agitados durante 30 segundos. Diluições seriadas foram semeadas em Ágar Sabouraud dextrose e incubadas a $37^{\circ} \mathrm{C}$ por 24 horas e, em seguida, o número de Unidades Formadoras de Colônias (UFC) foi contado. Os resultados mostraram que o método combinado (escova de dentes e imersão Polident) foi mais eficaz na redução do crescimento de $C$. albicans. Todos os métodos foram significativamente diferentes do grupo controle. O grupo controle apresentou a maior contagem de colônias de $C$. albicans e a imersão em água destilada e esterilizada foi ineficaz na remoção de $C$. albicans. O método mecânico, o Polident e associação entre eles foram mais eficazes que o gluconato de clorexidina a $0,12 \%$ e a irradiação com luz UV. Os autores concluíram que a imersão em pastilhas efervescentes, a escovação e associação entre ambos os métodos reduziram significativamente a aderência de $C$. albicans à resina acrílica.

Rossato et al. (2011) avaliaram efetividade de seis higienizadores na remoção do biofilme. Quinze estudantes utilizaram aparelhos maxilares e foram aleatorizados em 6 grupos: 1) Lavar em água corrente (20 segundos); 2) e 3) Corega Tabs por 5 e 30 minutos, respectivamente; 4) Escovação com sabonete líquido (40 segundos); 5) Hipoclorito de sódio a 0,5\% (10 minutos); 6) Q'boa ${ }^{\circledR}$ a $0.45 \%$ (10 minutos). Após a aplicação do protocolo de higiene, os aparelhos foram evidenciados, fotografados e submetidos ao método de pesagem. Os resultados mostraram que a solução de hipoclorito de sódio apresentaram os melhores resultados para a remoção do biofilme, seguido pela solução diluída de Q'boa® e escovação com sabonete líquido. O Corega Tabs® quando utilizado por 30 minutos apresentou melhor ação e mais próxima ao hipoclorito de sódio, do que por 5 minutos.

Fernandes et al. (2011) realizaram um estudo in vitro, para avaliar a eficácia de higienizadores de próteses, sobre o biofilme formado por espécies de Candida, em resina poliamida. Dois tipos de resina foram utilizados como substrato, a polimetil metacrilato polimerizada por micro-ondas e a termoplástica poliamida. Biofilmes formados por C. albicans, 
C. glabrata, e por ambas as leveduras foram estudados. Os higienizadores testados foram duas soluções à base de peróxido alcalino (Polident por 3 minutos e Corega Tabs por 5 minutos), hipoclorito de sódio a 0,5\% (10 minutos) e água destilada (controle, por 10 minutos). O ângulo de contato, a energia livre de superfície e o número de unidades formadoras de colônia de $C$. albicans e C. glabrata foram as variáveis do estudo. Para a avaliação da eficácia dos produtos na remoção do biofilme, os espécimes foram distribuídos em 24 grupos (8 espécimes). Após a contaminação dos espécimes com as leveduras, estes eram imersos em uma das quatro soluções testadas. A contagem dos micro-organismos que permaneceram aderidos aos materiais após as imersões foi realizada logo depois da colocação das resinas em aparelho ultrassônico, uma vez que este procedimento permitia o desprendimento das células remanescentes da superfície das resinas. O biofilme formado por Candida foi encontrado em maior quantidade na resina poliamida. Todos os higienizadores testados foram capazes de reduzir o número de Candida em ambos os materiais. O hipoclorito alcalino foi o único tratamento efetivo, pois após sua utilização, nenhuma célula viável foi encontrada.

Dhamande et al. (2012) compararam a capacidade de remoção de biofilme de Cândida de 3 higienizadores de próteses totais. Foram confeccionados 120 corpos de prova que foram contaminados com suspensão de $3 \times 10^{7}$ células de C.albicans $/ \mathrm{mL}$ e incubados ( $37^{\circ} \mathrm{C} / 2 \mathrm{horas}$ ); e em seguida, foi acrescentado $2 \mathrm{~mL}$ de Sabouraud em cada poço da placa de cultura e foram novamente incubados (6dias/144h). Os corpos de prova foram imersos nas seguintes soluções higienizadoras, por 8 horas ( $\mathrm{n}=30 /$ grupo): Viclean Power (hipoclorito de sódio), Clinsodent Power (peróxido alcalino) e Fittydent Tablets (peróxido) e o número de colônias foi contado. Em uma segunda análise do estudo, a partir de pré-culturas de C. albicans uma suspensão de $3 \times 10^{7}$ células $/ \mathrm{mL}$ foi obtida. Para cada $5 \mathrm{~mL}$ da suspensão, foi adicionado $5 \mathrm{~mL}$ de solução higienizadora em um tubo de ensaio. Esses tubos foram incubados a $37^{\circ} \mathrm{C}$ por $5,30,60,90 \mathrm{e}$ 120 minutos. A densidade óptica de cada solução (suspensão-solução higienizadora) foi avaliada por um fotocolorímetro. Como resultado, observaram uma diminuição de UFC após a imersão das amostras em todas as soluções higienizadoras. A densidade óptica diminuiu para todas as amostras, o que significou uma diminuição de células de C. albicans devido a ação dos higienizadores. Entre os higienizadores, o Viclean Powder e o Clinsodent Powerd apresentaram maior diminuição da densidade quando comparados ao Fittydent. Os autores concluíram que o higienizador Clinsodent teve maior capacidade de remoção Cândida devido presença de Lauril Sulfato de Sódio. 
Ramage et al. (2012) compararam a eficácia de remoção de C. albicans de protocolos de higienização de prótese. Corpos de prova de $1 \mathrm{~cm}^{2}$ de resina acrílica (Chaperlin/Jacobs Ltda) foram preparados segundo as instruções do fabricante e esterilizados com luz ultravioleta por 15 minuto. Após a inoculação de $1 \times 10^{6}$ células de $C$. albicans $/ \mathrm{mL}$ os corpos de prova foram incubados $\left(37^{\circ} \mathrm{C} / 4\right.$ horas) e expostos aos seguintes tratamentos higienizadores: (A) Polident peróxido alcalino - uso diários por 3 minutos, seguindo recomendações do fabricante durante 4 dias ou (B) Polident - Uso intermitente $-1^{\circ}$ e $4^{\circ}$ dias, e escovação com dentifrício (Colgate Cavity Protection e escova macia Oral B - durante 2 segundos) no $2^{\circ}$ e $3^{\circ}$ dia. Após cada tratamento os corpos de prova foram transferidos para tubos de ensaio e agitados por 5 minutos em ultrassom. Diluições seriadas foram semeadas e incubadas para contagem das células viáveis após tratamento. Os corpos de prova após os tratamentos foram lavados em PSB, fixados em paraformaldeído 2\%, glutaraldeído 2\% e Alciom Blue 0,15\% para a análise em microscopia eletrônica de varredura. A inibição da atividade metabólica do biofilme pelo uso dos higienizadores foi determinada usando XTT e a resposta inflamatória do biofilme pelo teste de Elisa. Para esse teste os corpos de prova após higienização foram colocados em culturas de células, por 245 horas a $37^{\circ} \mathrm{C}$ e $5 \%$ de $\mathrm{CO} 2$. Os sobrenadantes das células foram removidos e usados para o teste de Elisa. Os resultados mostraram o tratamento com o Polident inibiu o crescimento de biofilme de C. albicans após 4 horas, sendo mais efetivo o tratamento sequencial que o intermitente. O Polident foi mais eficaz que o dentifrício. O teste de Elisa indicou a redução da produção de IL-8, após tratamento com o Polident. Os autores concluíram que a presença de biofilme maduro pode resultar em elevado níveis de inflamação, o qual pode ser controlado por regimes de tratamento químico diário para a manutenção de uma boa saúde oral.

Kumar et al. (2012) testaram a eficácia de 2 higienizadores de dentaduras disponíveis no mercado e 2 produtos domésticos sobre a adesão de Candida albicans na resina acrílica da base das próteses totais. Cinquenta espécimes de resina acrílica $(10 \times 10$ x $2 \mathrm{~mm})$ foram confeccionados, esterilizados e divididos em 5 grupos: (1) Clinsodent (lauril sulfato de sódio em pó); Fittydent (hipoclorito de sódio em pastilhas); (3) vinagre (ácido acético a 4\%); (4) vinagre diluído em água (1:2) e (5) água (controle). Após incubação em meio de cultura Sabouraud inoculado com C. albicans, por 16 horas a $37^{\circ} \mathrm{C}$, os espécimes foram lavados e imersos nos higienizadores avaliados por 8 horas. Após esse período, os espécimes foram lavados, fixados com metanol e corados com cristal violeta. As células de Candida aderidas foram contadas por meio de microscópio. Todos os higienizadores testados apresentaram 
eficácia sobre a redução do número de células de C. albicans aderidas, porém os higienizadores de próteses totais disponíveis no mercado (Fittydent e Clinsodent) foram mais efetivos que os produtos domésticos (vinagre e vinagre diluído).

Porta et al. (2013) avaliaram, por meio de um estudo clínico, o efeito do hipoclorito de sódio a $0,5 \%$ quanto ao controle do biofilme, alteração de cor e rugosidade de superfície de próteses totais. Quinze participantes foram instruídos a imergir suas próteses diariamente, após escovação noturna, em solução de hipoclorito de sódio a $0,5 \%$ por três minutos, durante 90 dias. Coletas do biofilme das próteses foram realizadas a partir de um swab e cultivadas em CHROMagar e Águar sangue. As unidades formadoras de colônias (UFC) foram contadas após um período de 48 horas de incubação. As próteses totais foram avaliadas também quanto à alteração de cor por um espectrofotômetro portátil pelo sistema CIELab e alteração da rugosidade de superfície por meio de um perfilômetro. Os resultados mostraram uma redução significante no número total de micro-organismos $(\mathrm{p}=0,001)$ e Candida spp.. Não foi encontrada diferença significante para alteração de cor $(\mathrm{p}=0,68)$ e alteração da rugosidade de superfície $(\mathrm{p}=0,47)$. Concluiu-se que a solução de hipoclorito de sódio a $0,5 \%$ foi efetiva na redução dos micro-organismos sem sofrer alterações significantes de cor e rugosidade de superfície da resina acrílica.

Duyck et al. (2013) compararam tipos de armazenamento noturno de próteses, em relação à presença de biofilme e sua composição. Cinquenta e um participantes foram aleatorizados em grupo paralelo, foram considerados 3 métodos de armazenamento: (i) água, (ii) seco, (iii) água com uma pastilha de Corega Tabs Anti-bacteria®. Amostras do biofilme foram coletadas após 7 (desenvolvimento de biofilme - dBF) e 14 dias (maturação de filme MBF) de uma região padronizada, situada na porção distal aos segundos pré-molares inferiores. Os níveis totais e individuais de espécies perio-patogênicas e comensais selecionadas $(\mathrm{n}=20)$, e de Candida albicans foram avaliadas por PCR. Os resultados mostraram que o armazenamento de dentaduras durante a noite com peróxido alcalino diminuiu significativamente o número de colônias das espécies avaliadas de $\mathrm{dBF}$ e $\mathrm{mBF}$ até $13,8 \%$. As quantidades mais baixas de C. albicans foi encontrada no armazenamento com a pastilha de peróxido alcalino, em comparação com o armazenamento em água, registradas em $\mathrm{dBF}$ e mBF $(69,3,3,8 \%$ e $75,93,2 \%$, respectivamente). A massa e a patogenicidade de dBF e mBF foram iguais, independentemente da intervenção de armazenamento durante a noite. Concluiu-se que o uso de pastilhas efervescentes no armazenamento de prótese reduz a massa e a patogenicidade 
do biofilme dentário em comparação com a preservação na água ou ao seco, e pode contribuir para a saúde sistêmica geral.

Pinelli et al. (2013) compararam a efetividade de Ricinus communis (RC), Nistatina (NYS) e Miconazol (MIC), no tratamento de idosos institucionalizados com Estomatite Protética. Trinta idosos foram distribuídos, aleatoriamente, em 3 grupos: MIC: aplicação na forma de gel; NYS: aplicação com conta-gotas sobre a língua; RC (Perioquil): enxaguatório bucal, os quais foram usados 4 vezes ao dia. As avaliações clínicas e micológicas foram realizadas antes do uso dos antifúngicos (baseline) e após 15 e 30 dias de tratamento. As análises clínicas foram feitas por meio do exame das condições da mucosa oral, por meio de fotografias do palato e a classificação da Estomatite Protética (Classificação de Newton). As análises micológicas foram feitas por meio de coleta de material da mucosa do palato e Candida spp. foram quantificadas através de número de Unidades Formadoras de Colônias (UFC/mL). Quanto à remissão dos sinais clínicos da estomatite protética, o grupo NYS não apresentou diferença estatisticamente significante durante as análises, enquanto os grupos MIC e RC mostraram melhora nos sinais clínicos da estomatite entre o baseline e o $30^{\circ}$ dia e entre o $15^{\circ} \mathrm{e}$ o $30^{\circ}$ dia. Nenhum dos grupos mostrou redução significante de UFC/mL durante as análises. Portanto, Ricinus communis mostrou-se efetivo na remissão dos sinais clínicos da Estomatite Protética, sendo uma alternativa viável para o tratamento de idosos institucionalizados.

Andrade et al. (2014) avaliaram a eficácia da solução de Ricinus communis na propriedade de remoção de biofilme de próteses totais, quando comparada às soluções de hipoclorito de sódio e peróxido alcalino. Cinquenta e cinco desdentados totais foram orientados a escovar a prótese após as refeições e imergi-las uma vez ao dia nas soluções: Salina por 20 minutos, peróxido alcalino Polident ${ }^{\circledR}$ por três minutos, hipoclorito de sódio a $1 \%$ e solução de Ricinus communis a $2 \%$, por 20 minutos. Cada solução foi utilizada durante sete dias consecutivos, seguindo uma sequência randomizada. Após cada período de sete dias, a superfície interna da prótese total foi corada com vermelho neutro a $1 \%$ e fotografada, para quantificação do biofilme com software (Image Tool 3.0). Os resultados mostraram que as maiores e menores porcentagens de biofilme foram encontrados para a solução salina e hipoclorito de sódio a $1 \%$, respectivamente, enquanto Polident ${ }^{\circledR}$ e a solução de Ricinus communis apresentaram resultados intermediários. Concluiu-se que a solução de hipoclorito de sódio foi a mais efetiva e que a solução de Ricinus communis apresentou efetividade semelhante aos peróxidos alcalinos. 
Lucena-Ferreira et al. (2014) investigaram o efeito da exposição diária a um higienizador sobre biofilme de múltiplas espécies. Corpos de prova cilíndricos $(10 \times 2 \mathrm{~mm}) \mathrm{de}$ resina acrílica (QC-20 PMMA; Dentsply) foram confeccionados segundo instruções do fabricante. Os corpos de prova foram polidos de ambos os lados e a rugosidade de superfície padronizada $(0,32 \pm 0,03)$. Em seguida, foram lavados com água destilada estéril e com ultrassom para remoção dos resíduos da superfície. A esterilização foi realizada com óxido de etileno. Algumas amostras adicionais foram imersas em meio TSB (Trypticase Soy Broth) em condições aeróbicas durante 48 h, a fim de confirmar a ausência de contaminação microbiana. A eficácia do processo de esterilização foi confirmada pela ausência de turvação média. Um biofilme misto composto por seis micro-organismos, sendo cinco bactérias (Actinomyces naeslundii, Veillonella dispar, Fusobacterium nucleatum, Streptococcus mutans $e$ Streptococcus oralis) e uma levedura (Candida albicans) foi desenvolvido. Todas as cepas foram cultivadas individualmente. Após $15 \mathrm{~h}$ de incubação a $37^{\circ} \mathrm{C}$, alíquotas destas préculturas foram transferidas para um novo tubo e incubadas a $37^{\circ} \mathrm{C}$ durante $7 \mathrm{~h}$. Durante a preparação do inóculo, as bactérias foram incubadas em meio anaeróbico e C. albicans em condições aeróbicas. Após a maturação do biofilme, os corpos de prova foram distribuídos aleatoriamente em grupos controle (sem tratamento) e experimental. No grupo experimental, os corpos de prova foram submetidos a imersões diárias durante 3 minutos em um peróxido alcalino com enzima (Polident - 3 Minutos) durante sete dias consecutivos. Decorrido o tempo de imersão, os corpos de prova foram lavados em solução salina, transferidos para tubos contendo $3 \mathrm{~mL}$ de solução salina e colocados no ultrassom $(7 \mathrm{~W})$ por 30 segundos. A suspensão resultante foi utilizada para análise do biofilme. Alíquotas diluídas foram semeadas em meios de cultura específicos. As análises foram feitas nos dias 1, 4, e 7 pelo número de microorganismos e concentrações de polissacarídeos. Análises em microscopia eletrônica de varredura (MEV) e microscopia confocal (CLSM) foram também realizadas. O estudo demonstrou que o total de micro-organismos foi menor com uso do Polident, quando comparado ao grupo controle, para todos os períodos avaliados. No entanto, o número total de C. albicans aumentou em todos os biofilmes expostos ao higienizador, sendo identificadas hifas nas imagens do MEV E CLSM. A concentração de polissacarídeo foi significativamente maior no grupo experimental após 7 dias. Os autores concluíram que o uso diário de um higienizador de dentadura reduz o número de micro-organismos de biofilmes de múltiplas espécies. 
Nishi et al. (2014) compararam a higienização por ultrassom combinada com a imersão em peróxido alcalino (Polident ${ }^{\circledR}$ ) com outros métodos de higiene de próteses, foram avaliados a presença de micro-organismos antes e após os procedimentos de higiene. Cem usuários de próteses totais, residentes a uma casa de repouso (idade média: 84,6 anos), foram distribuídos aleatoriamente em cinco grupos: (A) imersão em Polident®, (B) escovação com água, (C) Ultrassom com água, (D) método (A) seguido pelo método (B) e (E) Ultrassom associada a imersão em Polident ${ }^{\circledR}$. Antes e após os métodos de higiene, o biofilme foi coletado. Os microorganismos coletados foram cultivados, identificados e quantificados. Os métodos de higiene que envolveram o uso da solução Polident ${ }^{\circledR}$ (métodos A, D e E) foram significativamente mais eficazes do que nos outros métodos $(\mathrm{p}<0,05)$. A maior na redução de Candida spp. foi apresentado após o uso do método E comparado aos métodos A, B e C. Concluiu-se que a higienização por ultrassom associado a solução de Polident ${ }^{\circledR}$ é efetiva na redução de microorganismos e pode ser considerado um método adequado para indivíduos idosos com dificuldade de escovar suas próteses.

Malheiros-Segundo et al. (2014) avaliou, in vivo, a eficácia de métodos de higiene na remoção do biofilme da prótese total inferior reembasada com reembasador resiliente. Trinta pacientes tiveram suas próteses inferiores reembasadas e, aleatoriamente, distribuídos em 3 grupos: (A) Método mecânico: escovação com dentifrício (Corega Brite) e escova (Johnson \& Johnson) específicos para prótese total; (B) Método químico: imersão em solução à base de Ricinus communis a 2\%; (C) Método associado (A+B). Para a quantificação do biofilme, a superfície interna da prótese total inferior foi evidenciada (Fluoresceína sódica a 1\%) e fotografada, após 15, 30 e 60 dias de utilização dos métodos. As áreas, total da prótese e a corada (biofilme), foram mensuradas por meio de um software (Image Tool 3.0), e a análise microbiológica foi realizada pela técnica de hibridização de DNA checkerboard. Para a avaliação qualitativa do material reembasador, foram atribuídos escores, em função da apresentação do material após os períodos avaliados. Após 60 dias, o acúmulo de biofilme foi maior que após 15 e 30 dias de utilização dos métodos. As próteses higienizadas pelo método mecânico apresentaram a menor porcentagem de área de biofilme e o menor nível de degradação do reembasador; e o método químico apresentou maior eficácia na diminuição de contagem de micro-organismos, inclusive nas espécies de Candida testadas (C. albicans, $C$. glabrata, C. dubliniensis, C. krusei e C. tropicalis) e S. mutans. 
Leite et al. (2014) testou um dentifrício experimental à base de mamona para higiene de próteses totais, por meio da análise microbiológica frente a micro-organismos específicos $(S$. aureus, E. coli, S. mutans, E. faecalis, C. albicans, C. glabrata e B. subtilis). Foram obtidos dentifrícios experimentais a 1, 2, 5 e 10\%, cuja ação antimicrobiana pelo método do poço difusão em Ágar foi avaliada em comparação com dentifrícios comerciais (Colgate, Trihydrall e Dentu-Creme), mostrando que nenhum dentifrício experimental foi efetivo contra E. coli e espécies de Candida e a concentração de $10 \%$ resultou nas maiores médias dos diâmetros dos halos de inibição frente aos demais micro-organismos. A ação antimicrobiana do dentifrício experimental a $10 \%$ foi então analisada pelo método de formação de biofilme sobre espécimes de resina acrílica. Após a contaminação, os espécimes foram escovados manualmente por 60 segundos com água (controle) e os dentifrícios: (A) Colgate; (B) Experimental a 10\%; (C) Dentu-Creme e (D) Trihydall e imersos em meio de cultura líquido, o qual foi semeado em meio de cultura sólido específico. A atividade antimicrobiana do dentifrício B variou em função da cepa e apresentou semelhança a alguns dentifrícios comerciais; houve redução de UFC/10mL de todos os micro-organismos analisados, mostrando efetividade contra E. faecalis, C. glabrata, E. coli e $S$. aureus, mas não houve diferença estatisticamente significante entre o dentifrício experimental e o grupo controle positivo para B. subtilis, S. mutans e C. albicans. O autor salientou que alterações na formulação do dentifrício experimental são necessárias para que se obtenha uma maior ação antimicrobiana.

Salles et al. (2015a) avaliaram a ação antimicrobiana de soluções de hipoclorito alcalino $(0,25 \%$ e $0,5 \%)$ e Ricinus communis a $10 \%$ frente a micro-organismos específicos. Sessenta e quatro usuários de próteses totais superiores foram orientados a escovar suas próteses três vezes ao dia e imergí-las (20 minutos/dia) nas soluções: SH1: Hipoclorito de sódio 0,25\%; SH2: Hipoclorito de sódio 0,5\%; RC: Mamona (Ricinus communis) 10\% e C: Solução salina a 0,85\% (controle). As soluções foram usadas por 7 dias em sequência aleatória. Após cada período de uso, houve período de wash out de 7 dias. A avaliação da ação antimicrobiana foi determinada pela contagem de Unidades Formadoras de Colônias (UFC) de Streptococcus mutans, Candida spp., e micro-organismos gram-negativos. Para colheita do biofilme, a superfície interna das próteses superiores foi escovada com solução salina e a suspensão de biofilme obtida. Após diluições $\left(10^{0}\right.$ até $\left.10^{-3}\right)$, alíquotas foram semeadas em Mitis Salivarius, Chromagar Candida® e Mac Conkey Agar para a detecção de S.mutans, Candida spp. ou gram negativos, respectivamente. Após incubação, colônias foram contadas e o valor de UFC/mL calculado. 
Após transformação - $\log 10$ (UFC+1) -os dados foram analisados por meio do teste de Friedman $(\alpha=0,05)$. As três soluções apresentaram ação antimicrobiana sobre S. mutans. Contra Candida spp., as soluções RC e SH1 mostraram efeitos semelhantes, enquanto SH2 mostrou atividade superior. As soluções de SH1 e SH2 apresentaram ação antimicrobiana sobre os microorganismos gram negativos. A espécie de Candida mais frequentemente isolada foi C.albicans, seguida pelas espécies $C$. tropicalis e $C$. glabrata. Concluiu-se que a solução de hipoclorito de sódio $0,5 \%$ foi a solução mais efetiva, podendo ser utilizada para o controle do biofilme protético. C. albicans foi a espécie de Candida mais frequentemente isolada.

Salles et al. (2015b) avaliou, por meio de estudo in vitro, a ação antimicrobiana de soluções de hipoclorito alcalino $(0,25 \%$ e $0,5 \%)$ e à base de mamona $10 \%$ frente a microorganismos específicos, por meio da contagem de Unidades Formadoras de Colônias (UFC) de bactérias clinicamente importantes e espécies de Candida. Espécimes de resina acrílica ( $\mathrm{n}=320$; Lucitone 550) foram obtidos a partir de matrizes metálicas quadrangulares (10 x $10 \times 2 \mathrm{~mm})$, esterilizados por micro-ondas (650W, por 6 minutos) e contaminados com Staphylococcus aureus, Pseudomonas aeruginosa, Candida albicans, Bacillus subtilis, Escherichia coli, Streptococcus mutans, Enterococcus faecalis e Candida glabrata. Os espécimes foram imersos por 20 minutos em uma das seguintes soluções higienizadoras (n=10/cada): A - Hipoclorito de sódio 0,25\%; B - Hipoclorito de sódio 0,5\%; C - Solução de mamona a 10\% e D (Controle) solução salina. As células aderidas foram suspensas e inoculadas em meio sólido seletivo $\left(37^{\circ} \mathrm{C}\right.$ por 24 horas). Foi realizado o teste t de Student $(\alpha=0,05)$ para comparar $\log 10(\mathrm{UFC}+1) / \mathrm{mL}$ entre os grupos C e D. Os resultados mostraram que as soluções de hipoclorito de sódio $(0,25 \%$ e $0,5 \%$ ) eliminaram completamente todos os micro-organismos. A solução de mamona eliminou B. subtilis e reduziu as contagens das outras cepas. As diferenças entre C e D foram significantes $(\mathrm{p}<0,05)$ para todas as espécies, exceto para E. faecalis. Ambas as soluções de hipoclorito de sódio $(0,25 \%$ e $0,5 \%)$ foram efetivas na eliminação de todos os microorganismos avaliados, e pode ser usada como soluções higienizadoras de próteses totais. A solução de mamona apresentou eficácia moderada e agiu diferentemente sobre as espécies testadas, com efeito ação superior sobre $B$. subtilis e com ação não-significante sobre $E$. faecalis.

Meriç; Güvenir; Süer (2016) avaliaram a efetividade do ácido húmico na remoção de micro-organismos sobre a prótese total. Amostras quadradas de resina acrílica foram preparados e divididos em cinco grupos $(n=110 /$ grupo $)$ correspondentes à contaminação 
microbiana (Candida albicans, Staphylococcus aureus, Bacillus cereus, Enterococcus faecalis, Pseudomonas aeruginosa). As amostras contaminadas foram distribuídas aleatoriamente para a aplicação de cinco agentes de limpeza de dentaduras diferentes da seguinte forma $(n=20$ para cada um): Kloroben, Corsodyl, Steradent, Corega, solução experimental com ácido húmico. Além disso, foram utilizados dois grupos controle: negativo e positivo ( $\mathrm{n}=5$ para cada $u m$ ). Todos as amostras foram incubadas a $37^{\circ} \mathrm{C}$ durante $24 \mathrm{~h}$ (para cepas bacterianas) e $37^{\circ} \mathrm{C}$ durante 48 h (para cepas de levedura). O número de unidades formadoras de colônias (CFU / ml) foi calculado. Corsodyl e Kloroben eliminaram completamente a adesão de todos os microorganismos investigados (100\%) e apresentaram a maior efetividade de remoção do biofilme em comparação com outros higienizadores $(\mathrm{p}<0,05)$. Não houve diferença estatisticamente significativa entre Corsodyl e Kloroben ( $\mathrm{p} \geq 0,05)$, e não houve diferença estatisticamente significante entre Corega, Steradent e solução experimental $(\mathrm{p} \geq 0,05)$. Concluiu-se que o ácido úmico pode ser usado como uma solução alternativa "natural" para o agente de limpeza de dentaduras.

Coimbra et al. (2016) avaliaram a eficácia da ação antimicrobiana de peróxidos alcalinos, através de um estudo in vitro. Amostras circulares de resina acrílica foram obtidas e esterilizadas por irradiação de micro-ondas (650 W, 6 minutos). As amostras foram contaminadas com suspensões de Candida albicans (Ca), Candida glabrata $(\mathrm{Cg})$, Staphylococcus aureus (Sa), Streptococcus mutans (Sm), Bacillus subtilis (Bs), Enterococcus faecalis (Ef), Escherichia coli (Ec), e Pseudomonas aeruginosa (Pa). Após contaminação, as amostras foram incubadas (37\% 48 horas) e imersas em uma das soluções: (PC): controle positivo - solução PBS; (MI): Medical Interporous; (EF): Efferdent Plus; (CT): Corega Tabs e $(\mathrm{NC})$ : controle negativo $(\mathrm{n}=5)$, sem contaminação e imersão em PBS. Após incubação $\left(37^{\circ} / 24\right.$ horas), o número de colônias foi contado e calculado. MI foi efetivo para $\mathrm{Ca}, \mathrm{Cg}, \mathrm{Sa}, \mathrm{Sm}, \mathrm{Ef}$, Ec e Pa; EF foi efetivo para Cg, Sm, Ef, Ec e Pa; e CT apresentou ação para Sa, Bs e Ec, quando comparado a PC.

Peracini et al. (2016) avaliaram a eficácia de soluções higienizadoras na remoção do biofilme protético através de um estudo clínico randomizado. Trinta e dois pacientes desdentados totais foram orientados a escovar suas próteses três vezes ao dia, com sabonete líquido e escova específica, e imergí-las por 8 horas/dia em: (1) controle - água; (2) Peróxido alcalino - Pastilhas Corega Tabs®; (3) hipoclorito de sódio a 0.5\%. Cada solução foi utilizada durante 21 dias, dividido em três ciclos de 7 dias. Ao final de cada ciclo, a superfície interna 
das próteses totais superiores foi evidenciada com vermelho neutro a $1 \%$ e fotografada. As áreas (total e evidenciada pelo biofilme) foram medidas pelo software Image Tool e a porcentagem de biofilme foi calculada pela divisão entre a área total de biofilme, multiplicada por 100 e a área total da prótese. Os resultados mostraram que a imersão em hipoclorito de sódio apresentou a maior redução do biofilme $(8,3 \pm 13,3 \mathrm{~B})$, enquanto a solução de peróxido alcalino $(18,2 \pm$ $16,6 \mathrm{~A})$ foi semelhante ao controle $(18,2 \pm 14,9 \mathrm{~A})$. A solução de hipoclorito de sódio a $0.5 \%$ foi a mais efetiva na redução do biofilme. Os peróxidos alcalinos podem não ser os principais atuantes na remoção de biofilme, em pacientes com hábitos adequados de higienização de próteses dentárias.

Panariello et al. (2016) investigaram a eficácia da imersão e escovação frente a biofilme multiespécies. Amostras ( $\mathrm{n}=10)$ de Lucitone 550 (L) e Tokuyama Rebase Fast II (T) foram preparados, esterilizados e inoculados com suspensão de Candida albicans, Candida glabrata, e Streptococcus mutans. As amostras foram incubadas por 48 horas a $37^{\circ} \mathrm{C}$ para a formação do biofilme, e foram divididas em grupos $(n=12)$ para escovação ou imersão por 10 segundos em água destilada, ácido peracético a 0,2\%, digluconato de clorexidina a 1\%, 1:1 água/ solução de dentifrício, hipoclorito de sódio a $1 \%$ e Corega Tabs. Os micro-organismos viáveis foram avaliados pelo método de XTT e as unidades formadoras de colônia (UFC/Ml) foram contadas. $\mathrm{O}$ biofilme multiespécies em L e T foram reduzidos significantemente pela escovação ou imersão em ácido peracético a $0,2 \%$, digluconato de clorexidina a $1 \%$ e hipoclorito de sódio a $1 \%$ por apenas 10 segundos.

Pires et al. (2017) investigaram a eficácia antimicrobiana de diferentes agentes químicos utilizados para a higienização de próteses totais. As amostras de biofilmes foram coletadas de 10 próteses e foram submetidas a 10 protocolos de desinfecção: água destilada durante 30 min (controle negativo); $1 \%$ de hipoclorito de sódio durante $10 \mathrm{~min}$ (controle positivo); hipoclorito de sódio a 0,018\% durante $10 \mathrm{~min}$; vinagre por $20 \mathrm{~min}$; ácido peracético a 0,2\% durante $5 \mathrm{~min}$; Corega Tabs por $5 \mathrm{~min}$; Corega Tabs durante $30 \mathrm{~min}$; digluconato de clorexidina a 0,12\% durante $10 \mathrm{~min}$; solução de salicilato de sódio a 0,05\% durante $10 \mathrm{~min}$; e detergente enzimático durante 2 min. Cada uma das amostras foi semeada em placas de Petri com agar MuellerHinton. Os resultados mostraram que o hipoclorito de sódio diluído, o vinagre e o digluconato de clorhexidina inibiram o crescimento microbiano, com um efeito semelhante ao de $1 \%$ de hipoclorito de sódio. As soluções de ácido peracético a $0,2 \%$ e o salicilato de sódio a $0,05 \%$ foram ineficazes para inibir o crescimento microbiano, enquanto o detergente enzimático e o 
peróxido alcalino alcançaram um efeito intermediário. Concluiu-se que o hipoclorito de sódio diluído, o vinagre e o digluconato de clorexidina podem ser considerados produtos adequados para limpeza de próteses dentárias devido ao seu potencial de inibição do crescimento bacteriano, semelhante ao hipoclorito de sódio a $1 \%$. No entanto, o efeito desses agentes químicos em materiais de base de resina acrílica precisa ser examinado para fornecer informações consistentes sobre sua indicação clínica.

Peracini et al. (2017) avaliaram duas soluções de higiene em imersões de 8 horas (hipoclorito de sódio a $0,5 \%$ e Peróxido alcalino) quanto a ação antimicrobiana (avaliação clínica randomizada) e efeitos adversos sobre a resina acrílica, simulando 5 anos de uso (estudo laboratorial). Foi realizada a identificação de Candida spp. e resistência a agentes fungicos. Trinta e dois usuários de próteses totais foram instruídos a escovar suas próteses 3 vezes ao dia e imergí-las (8 horas) em: (1) Controle - água; (2) Peróxido Alcalino - Pastilhas Corega Tabs; (3) Hipoclorito de Sódio a 0,5\%. De acordo com a sequência de aleatorização, cada solução foi utilizada por três períodos alternados de 7 dias. A ação antimicrobiana foi realizada através da contagem de unidades formadoras de colônias (UFC) de Candida spp. Para a coleta do biofilme, as próteses superiores foram colocadas em placa Petri e escovadas (escova Tek) com solução salina (2 minutos). A solução obtida foi diluída $\left(10^{0}\right.$ to $\left.10^{-3}\right)$, e alíquotas $(50 \mu \mathrm{L})$ foram semeadas em Chromagar. Após incubação, as colônias foram contadas e os valores de UFC/mL calculados. A resistência a agentes fúngicos (Anfotericina B, nistatina, flucitosina, econazole, cetoconazol, miconazol e fluconazol) foram avaliadas. Os efeitos adversos foram avaliados em amostras de resina acrílica, que foram randomizadas em três grupos: (1) Controle - água destilada; (2) Peróxido alcalinos - Pastilhas Corega Tabs; (3) Hipoclorito de sódio a 0,5\%. Foram avaliadas a alteração de cor, rugosidade de superfície e resistência à flexão no baseline e após os procedimentos de imersão. Os resultados mostraram que tanto o hipoclorito de sódio como o peróxido alcalino foram capazes de reduzir o número de Candida spp. A espécie mais encontrada foi a $C$. albicans, seguida pela $C$. glabrata. Apenas $24,7 \%$ das cepas isoladas foram resistentes a pelo menos um antifúngico testado. Imersões no peróxido alcalino causou maior alteração de cor [5,73 $(5,45-5,91)]$, sendo que a solução controle apresentou os menores valores [1,12 (1,15-1,37)], seguido pelo hipoclorito de sódio [3,70 (3,51-3,98)]. Os valores de NBS classificou a alteração da solução controle como "leve" $(1,12)$ e "considerável" para peróxido alcalino $(5,27)$ e hipoclorito de sódio $(3,40)$. Nenhuma solução alterou consideravelmente a rugosidade de superfície. A resistência à flexão foi menor para a solução controle $(64,59)$, 
peróxido alcalino $(63,96 \pm 12.98)$ e hipoclorito de sódio $(62,84 \pm 8,62)$ quando comparado ao grupo sem imersão $(109,12 \pm 8,37)$.

Badaró et al. (2017) avaliaram soluções de Ricinus communis e hipoclorito de sódio frente a remoção do biofilme, remissão da estomatite protética, ação antimicrobiana e satisfação dos participantes. Sessenta e quatro usuários de próteses totais com $(n=24)$ ou sem $(n=40)$ estomatite foram instruídos a escovar (3 vezes/dia) e imergir as próteses (20 minutos/dia): S1/S2: hipoclorito de sódio a $0,25 \% /$ hipoclorito de sódio a $0,5 \%$; S3: R. communis a $10 \%$; S4: solução salina. O período de uso de cada solução foi de sete dias e foi estabelecido um período de washout (7 dias) antes de iniciar cada produto. As variáveis foram analisadas no baseline e após cada produto. O biofilme das próteses foi corado, fotografado e mensurado (Image Tool software). A porcentagem de biofilme foi calculada. A remissão da estomatite protética foi avaliada através de uma escala visual e escores. A análise da ação antimicrobiana foi realizada através do método de hibridização DNA-Checkerboard. A satisfação dos pacientes foi mensurada pela utilização de questionários. Os resultados mostraram que S1 e S2 foram mais efetivos do que S3 para a remoção do biofilme. S3 se mostrou a solução mais efetiva na redução dos sinais clínicos da estomatite protética (50\%), seguido por S1 (46\%). S1 e S2 foram semelhantes e apresentaram maior efetividade na redução do número de colônias, seguido por S3. Não houve diferença significante para a avaliação da satisfação dos pacientes. As soluções de Ricinus communis a $10 \%$ e hipoclorito de sódio a $0,25 \%$ foram efetivas na remoção do biofilme, remissão da estomatite protética e redução do número de Candida spp. da superfície de próteses totais. Todas as soluções foram aprovadas pelos pacientes.

Arruda et al. (2017) avaliaram, através de um estudo clínico randomizado, a eficácia de higienizadores de próteses totais quanto à remoção do biofilme, ação antimicrobiana e remissão da estomatite protética. Cinquenta usuários de próteses totais foram diagnosticados com estomatite protética e orientados a escovar as próteses (sabonete neutro e escova específica) e imergí-las em 4 soluções (20 minutos/14 dias): (1) Controle - Solução salina; (2) Hipoclorito de sódio a $0,1 \%$; (3) Hipoclorito de sódio a $0,2 \%$ e (4) Solução de Ricinus communis a 8\%. O biofilme da superfície interna das próteses superiores foi evidenciada, fotografada e quantificada (Image Tool). Para coleta do biofilme, as próteses superiores foram escovadas (escova Tek e solução salina) e a suspensão obtida foi diluída $\left(10^{0}\right.$ até $\left.10^{-3}\right)$ e alíquotas $(50 \mu \mathrm{L})$ foram cultivadas em CHROMagar para Candida spp. Após incubação, foi feito o cálculo dos valores de UFC/mL. A remissão da estomatite foi classificada de acordo com a classificação de 
Newton. Os resultados mostraram que os hipocloritos de sódio a $0,1 \%$ e $0,2 \%$ apresentaram menor área de biofilme, enquanto a solução de Ricinus communis a $8 \%$ foi semelhante ao controle. Para a ação antimicrobiana, os hipocloritos foram efetivos na redução de Candida spp., já a Ricinus communis a $8 \%$ foi semelhante ao controle e Baseline. Os sinais clínicos da estomatite protética mostraram melhora com o uso do hipoclorito de sódio a $0,1 \%$, enquanto o hipoclorito de sódio a $0,2 \%$ e Ricinus communis a $8 \%$ mostraram resultados intermediários. Concluiu-se que as duas soluções de hipoclorito de sódio foram as mais efetivas no controle do biofilme. Todas as soluções foram efetivas na redução dos sinais clínicos da estomatite protética.

Rocha (2018) avaliou, por meio de estudo in vitro, o efeito de soluções químicas de higienização quanto à ação antimicrobiana e aos efeitos adversos sobre a resina acrílica. Para a ação antimicrobiana, corpos de prova de resina acrílica $(15 \mathrm{~mm} \times 3 \mathrm{~mm})$ foram obtidos, esterilizados em micro-ondas (650W, por 6 minutos) e inoculados com Candida albicans, Candida glabrata e Streptococcus mutans. Após contaminação, os corpos de prova foram imersos em: Salina (controle); Solução à base de Ricinus communis a 6,25\%; Hipoclorito de sódio 0,2\%; Peróxido Alcalino Efferdent ${ }^{\circledR}$ Power Clean Crystals. A suspensão resultante foi diluída $\left(10^{0}\right.$ e $\left.10^{-3}\right)$ em solução salina estéril e alíquotas foram semeadas em meio específico. Após incubação $\left(37^{\circ} \mathrm{C}\right.$ por $\left.24 \mathrm{hs}\right)$, o número de colônias características foi mensurado e o número de UFC/mL calculado. Para os efeitos adversos, corpos de prova circulares $(15 \times 3 \mathrm{~mm})$ e retangulares $(65 \times 10 \times 3.3 \mathrm{~mm})$ de resina acrílica foram imersos nas soluções, simulando imersões curtas por período de higienização de 05 anos. Antes e após as imersões, foram avaliados quanto à alteração de cor; dureza Knoop; rugosidade de superfície; morfologia de superfície e resistência à flexão. Para os dados que apresentaram distribuição normal, foi empregado ANOVA, seguido pelo teste de Tukey; para os dados com distribuição não normal, foi empregado o teste de Kruskal-Wallis, seguido pelo teste de Dunn $(\alpha=0,05)$. Os resultados mostraram que o hipoclorito reduziu a zero o UFC dos três micro-organismos, a solução de Ricinus communis e o peróxido Efferdent tiveram ação moderada frente a Candida glabrata ( $\mathrm{p}<0,001)$ e Streptococcus mutans ( $\mathrm{p}=0,001)$, respectivamente. A solução de Ricinus communis apresentou alterações de cor $(\mathrm{p}=0,030)$, classificada como "leve" segundo NBS; maiores alterações de dureza $(p<0,001)$, rugosidade superficial $(p=0,006)$, microscópio 3D ( $p=0,040)$ e resistência à flexão $(\mathrm{p}<0,001)$. A maior alteração da morfologia de superfície (MEV) foi notada no grupo do peróxido Efferdent. Concluiu-se que a solução de hipoclorito de sódio a $0,20 \%$ foi 
a mais efetiva e não causou alterações clinicamente significantes nas propriedades da resina acrílica.

Pinheiro et al. (2018) identificou, clinicamente, os micro-organismos presentes em próteses e tecidos adjacentes, avaliou laboratorialmente a ação antimicrobiana de diferentes protocolos de higiene sobre os principais micro-organismos identificados e, ainda, avaliou a influência dos protocolos de higiene na alteração de cor, dureza Shore A, rugosidade superficial e absorção de líquidos, de um novo silicone (Bio-Skin), em comparação ao MDX 4-4210. Para identificação dos micro-organismos, 43 indivíduos portadores de próteses bucomaxilofaciais foram submetidos à colheita do biofilme na região da prótese e tecidos adjacentes e 38 espécies alvos de micro-organismos foram pesquisadas por meio do método de hibridação de DNA checkerboard. A análise da ação antimicrobiana foi conduzida por meio da formação de biofilmes específicos de 6 espécies selecionadas. 288 espécimes pigmentados com pó de maquiagem foram confeccionados com cada material, e distribuídos em grupos para imersão em gluconato de clorexidina a $0,12 \%$, Ricinus communis a $10 \%$, e escovação com sabão neutro. Como controle, um grupo foi imerso em água. Para análise da influência dos protocolos de higienização nas propriedades dos silicones, 120 corpos de prova circulares de cada material foram confeccionados $(\mathrm{n}=10)$ : sem pigmentação (GC: controle), com pó de maquiagem (GP), opacificador (GO) ou opacificador + pó de maquiagem (GPO), para então serem submetidos à higienização: EA (imersão em água destilada + escovação com sabão neutro - controle), ERc10\% (imersão em solução de Ricinus communis 10\% + escovação com sabão neutro) e EC10,12\% (imersão em gluconato de clorexidina $0,12 \%$ + escovação com sabão neutro). $\mathrm{O}$ período de higienização simulou um ano de uso clínico. As variáveis de resposta quantitativas foram mensuradas imediatamente após a obtenção dos espécimes e após a aplicação dos protocolos de higiene e a variação obtida foi utilizada na análise estatística. Para análise da ação antimicrobiana dos protocolos de higiene e para alteração de cor, dureza Shore A e rugosidade superficial, realizou-se Análise de variância e Teste Complementar de Tukey para comparação das médias. Para a absorção de líquidos, aplicou-se o Teste de Kruskal-Wallis. Para comparação da contagem de micro-organismos presentes nas próteses e tecidos adjacentes empregou-se o Teste de Wilcoxon.Para análise dos dados obtidos pela contagem de UFC, para análise da ação antimicrobiana dos protocolos de higiene, empregou-se Two-way ANOVA e Teste Complementar de Tukey. Todas as análises foram conduzidas com nível de significância $5 \%$. O método de hibridação de DNA checkerboard indicou a presença das 38 espécies nas próteses e 
tecidos adjacentes e foram selecionados os seguintes micro-organismos: C. glabrata, S. aureus, S. mutans, E. coli, E. faecalis e P. aeruginosa. Para a análise antimicrobiana, o gluconato de clorexidina a $0,12 \%$ foi o mais eficaz, seguido pela escovação mecânica, contra as 6 espécies. A alteração de cor não foi influenciada pelos protocolos de higiene e a menor alteração foi encontrada com o silicone Bio-Skin dos grupos GP e GPO. O silicone MDX apresentou menor variação de dureza Shore A em função do protocolo de higiene EC10,12\%, enquanto a dureza do Bio-Skin não foi influenciada pelos protocolos de higiene. A variação da dureza entre os dois silicones foi diferente somente quando submetidos ao protocolo ERc10\%. Para a rugosidade superficial, o silicone MDX apresentou a menor variação de rugosidade. A porcentagem de absorção de líquidos do silicone MDX 4-4210 não foi influenciada pela pigmentação ou protocolos de higienização. Para o Bio-Skin, a porcentagem de absorção foi maior nos grupos GC e GO quando submetidos ao protocolo EA. Nota-se que houve uma interação entre pigmento e protocolo de higiene, onde para o silicone MDX, a absorção foi maior quando submetidos ao protocolo ECl0,12\% e para o Bio-Skin, houve uma maior porcentagem de absorção nos grupos GC e GO associados à escovação e imersão em água e nos grupos GP e GPO associado ao protocolo EC10,12\%. Conclui-se que tanto as próteses quanto os tecidos adjacentes apresentam grande quantidade de micro-organismos colonizadores e que cuidados diários de higiene são essenciais. Os protocolos de imersão em gluconato de clorexidina a $0,12 \%$ e de escovação mecânica com sabão neutro possuem efetividade antimicrobiana sobre os principais micro-organismos comumente presentes em próteses e tecidos e o silicone MDX 4-4210 apresentou menor contagem de UFC quando comparado ao Bio-Skin. Ambos os materiais apresentaram variações em função das diferentes pigmentações e protocolos de higiene, entretanto, as mesmas foram discretas e dentro de padrões clínicos aceitáveis. As menores alterações foram observadas quando os materiais foram expostos aos protocolos de imersão em gluconato de clorexidina a $0,12 \%$ e escovação com sabão neutro.

Arruda et al. (2018) verificaram através de pesquisa clínica randomizada, se a soluções de hipoclorito de sódio ( $\mathrm{NaOCl}$ ) a $0,1 \%$ e $0,2 \%$ e Ricinus communis a $8 \%$ (RC) foram capazes de remover o biofilme de próteses totais sem causar efeitos deletérios a resina acrílica. Quarenta e sete usuários de próteses totais foram orientados a escovar suas próteses e imergi-las em uma das soluções (20 minuto/14 dias): Controle: solução salina a 0.85\%; $\mathrm{SH} 1: \mathrm{NaOCl}$ a $0.1 \%$; SH2: $\mathrm{NaOCl}$ a $0.2 \%$ e RC. O biofilme da superfície interna das próteses foi corado, fotografado e quantificado (Image Tool®). Além disso, 80 espécimes circulares (16 x 4 mm) e 80 retangulares 
$(65 \times 10 \times 3,3 \mathrm{~mm})$ de resina (Lucitone 550), que foram divididos em quatro grupos $(\mathrm{n}=20)$ de imersão (20 minutos): SH1: hipoclorito de sódio a 0,10\%; SH2: hipoclorito de sódio a 0,20\%; RC: Ricinus communis a 8\%; Controle: água corrente. Antes e após as imersões, os espécimes foram avaliados quanto à cor (Espectrocolorímetro Color Guide 45/0 e National Bureau of Standards-NBS), rugosidade de superfície (Rugosímetro Surftest SJ-201P) e resistência à flexão (Máquina Universal de Ensaios DL 2000). Os dados clínicos foram comparados por teste de Friedman $(\alpha=0,05)$ seguido por Wilcoxon, corrigido por Bonferroni $(\alpha=0,005)$ e os dados laboratoriais foram analisados por Kruskal-Wallis seguido pelo teste de Dunn $(\alpha=0,05)$. SH2 (MR=1,77) mostrou menor cobertura de biofilme, SH1 (MR=2,37) e RC $(\mathrm{MR}=2,74)$ apresentaram valores intermediários. RC $[1,10(0,96: 1,75)]$ mostraram maior alteração de cor do que SH1 [0,71 $(0,62: 0,80)]$ e SH2 [0,74 (0,58:0,85)]; no entanto, todas as soluções foram classificadas "leve" $(0,0-0,5)$ segundo a NBS. Não houve diferença estatística para as propriedades de rugosidade de superfície $(p=0,760)$ e resistência a flexão $(p=0,547)$. A solução de $\mathrm{NaOCl}$ a $0.2 \%$ apresentou a melhor performance clínica e ao mesmo tempo não causou efeitos adversos sobre a resina acrílica na análise laboratorial. 
3. Proposição 



\section{O objetivo geral deste trabalho foi:}

Avaliar através de estudo clínico randomizado o efeito de soluções químicas de higienização hipoclorito de sódio a $0,2 \%$, peróxido alcalino Efferdent ${ }^{\circledR}$ e solução experimental à base de mamona a 6,25\% (Ricinus communis) no controle do biofilme em próteses totais de pacientes desdentados bimaxilares.

\section{Os objetivos específicos foram:}

- Avaliar a propriedade de remoção do biofilme protético das soluções sobre as próteses totais superiores, por meio de método quantitativo computadorizado;

- Avaliar a ação antimicrobiana das soluções na higienização de próteses totais superiores e escovas, por meio da contagem de colônias de UFC/mL de Candida spp. e S. mutans;

- Avaliar a degradação das cerdas das escovas após o protocolo de higienização, de forma qualitativa, por meio de Microscopia Eletrônica de Varredura.

A hipótese nula deste estudo foi que as imersões nos diferentes higienizadores de próteses totais apresentariam o mesmo efeito que a solução controle em relação as propriedades testadas. 



\section{Materiale Métodos}





\subsection{AVALIAÇÃo CLÍNICA}

\subsubsection{Seleção dos pacientes}

Este projeto de pesquisa foi submetido à análise do Comitê de Ética em Pesquisa com Seres Humanos da Faculdade de Odontologia de Ribeirão Preto da Universidade de São Paulo (CAAE n: 48725015.6.0000.5419 - ANEXO A) e teve início após a obtenção do Consentimento Livre e Esclarecido (APÊNDICE A). O recrutamento foi realizado após a compreensão da natureza deste protocolo e assinatura do termo de consentimento livre e esclarecido.

Participaram desta pesquisa, 45 pacientes desdentados totais da clínica de Prótese Total da Faculdade de Odontologia de Ribeirão Preto (USP), com mucosa palatina saudável, de qualquer idade, de ambos os sexos, usuários de próteses totais superiores, com base e dentes artificiais confeccionados em resina acrílica. Foram incluídos os usuários de próteses totais superiores, sem Estomatite Protética, com pelo menos cinco anos de uso das próteses superiores. Os critérios de exclusão foram pacientes diagnosticados com Estomatite Protética, com doenças crônicas ou imunossupressoras, sem habilidades motoras e/ou cognitivas, usuários de próteses totais com reembasamento, reparo, fratura ou com menos de um ano de uso. A amostra foi calculada de acordo com um estudo piloto, utilizando os valores do baseline de 10 participantes, considerando um desvio padrão de 7,32 e uma média de porcentagem de biofilme de 43,05. Com esses parâmetros, o número de participantes necessários para a amostra foi de $45(\alpha=0,05$, poder $=0,80)$.

A presença de Estomatite Protética para exclusão de pacientes foi classificada por meio de escores de acordo com a Classificação de Newton (Bloem e Razoog, 1982), visando dessa forma, quantificar a inflamação presente no palato dos pacientes (Andruciolli et al., 2004): 0 (excelente) - rosa, vascularização normal e aspecto fosco; 1 (satisfatório) - avermelhada, focos solitários de hiperemia e aspecto fosco; 2 (regular) - avermelhada, focos hiperêmicos múltiplos e aspecto brilhante; 3 (insatisfatório) - nitidamente vermelho ou vermelho para azul e aspecto brilhante. Foram adicionados os participantes com scores iguais a 0 ou 1. 
Em relação à presença de biofilme, as próteses foram selecionadas de acordo com o Índice Aditivo (Ambjørnsen et al., 1984) da seguinte forma:

A. As próteses totais foram removidas da cavidade oral dos pacientes e enxaguadas em água corrente por 5 segundos para remoção do excesso de saliva e secas com um jato de ar por dez segundos;

B. A superfície interna foi dividida visualmente em cinco áreas: (1) papila incisiva; (2 e 3) duas áreas localizadas lateralmente a $1 \mathrm{~cm}$ da linha mediana e (4 e 5) área posterior de ambas as tuberosidades. (Figura 1).

C. O exame foi realizado sob iluminação do refletor de luz do equipamento odontológico e cada área foi visualmente limitada com um círculo de aproximadamente $1 \mathrm{~cm}$ de diâmetro;

D. O registro do biofilme foi realizado por meio da atribuição de escores para cada área, os quais variaram de zero a três: Escore 0: sem biofilme; Escore 1: biofilme visível ao raspar a superfície com brunidor em forma de pera (Millenium Golgran, Golgran Indústria e Comércio de Instrumental Odontológico, São Caetano do Sul, São Paulo, Brasil); Escore 2: acúmulo de biofilme moderado, visível na presença de luz; Escore 3: acúmulo abundante de biofilme visível na presença de luz;

E. Foram selecionadas as próteses com escore igual ou maior que 1 para cada área.

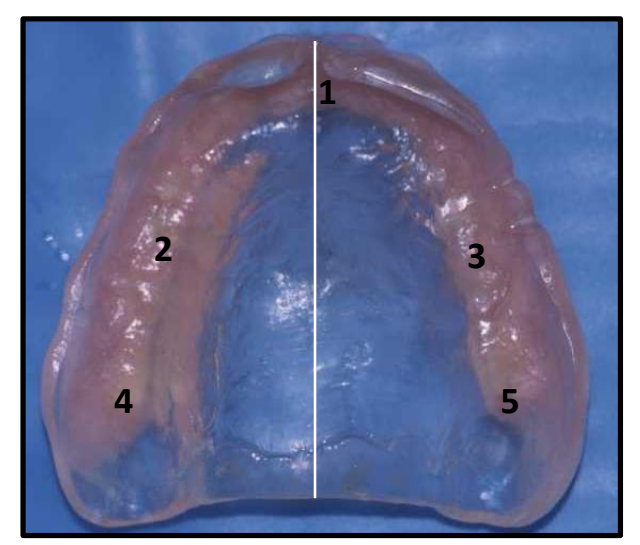

Figura 1. Áreas de avaliação do índice Aditivo.

Os pacientes receberam orientações para que mantivessem a higienização habitual de suas próteses, até receberem as instruções e materiais de higiene preconizados para o estudo. 


\subsubsection{Remoção do Biofilme}

Previamente à utilização das soluções higienizadoras, visando obtenção de um padrão inicial, as próteses dos voluntários foram higienizadas, para promover a total remoção do biofilme. As próteses totais do paciente foram enxaguadas em água corrente por 5 segundos e secas com jato de ar por dez segundos; a superfície interna (total) da prótese total superior foi evidenciada com Vermelho neutro a 1\% (Silva-Lovato; Paranhos; Ito, 2002) com auxílio de um swab (Figura 2) e, em seguida, as próteses foram enxaguadas por 5 segundos para remoção do excesso de evidenciador e secas por dez segundos (Figura 3).

As próteses coradas foram higienizadas, por meio de escovação (escova específica Denture - Condor S.A., Santa Catarina, Brasil e sabão líquido - JOB Química, Produtos para limpeza Ltda., Monte Alto, SP, Brasil) pelo pesquisador (figura 4), até que o corante fosse totalmente removido (figura 5), de forma que as próteses eram devolvidas adequadamente limpas aos pacientes.

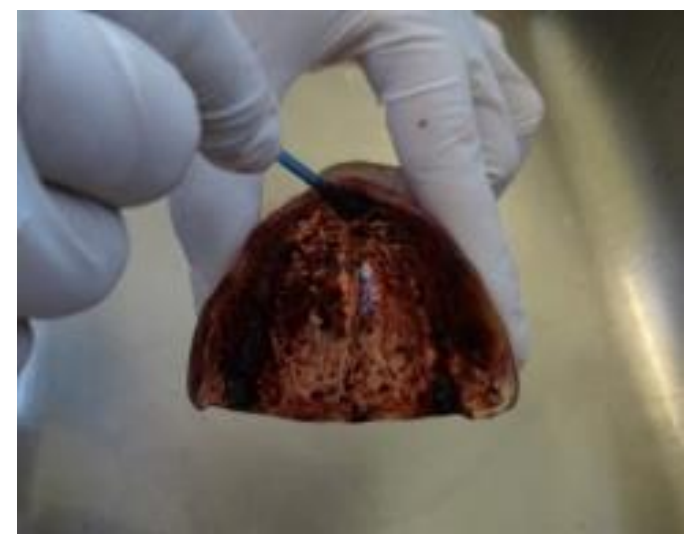

Figura 2. Aplicação do evidenciador de biofilme com vermelho neutro a $1 \%$.

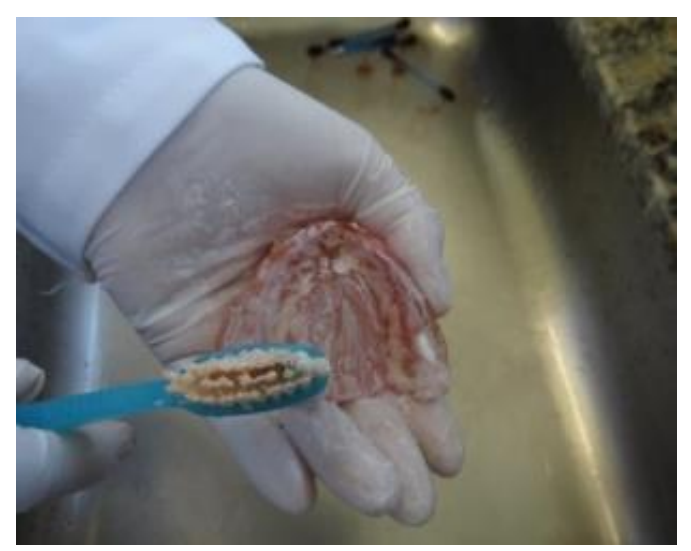

Figura 4. Higienização da prótese com escova específica e sabão neutro.

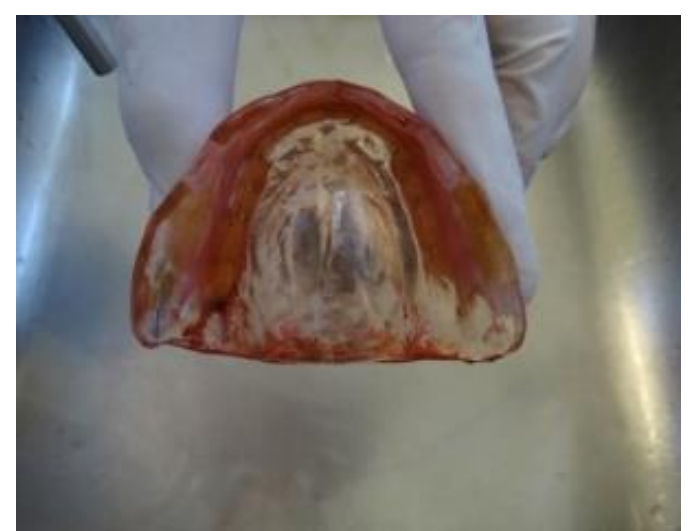

Figura 3. Prótese com biofilme evidenciado.

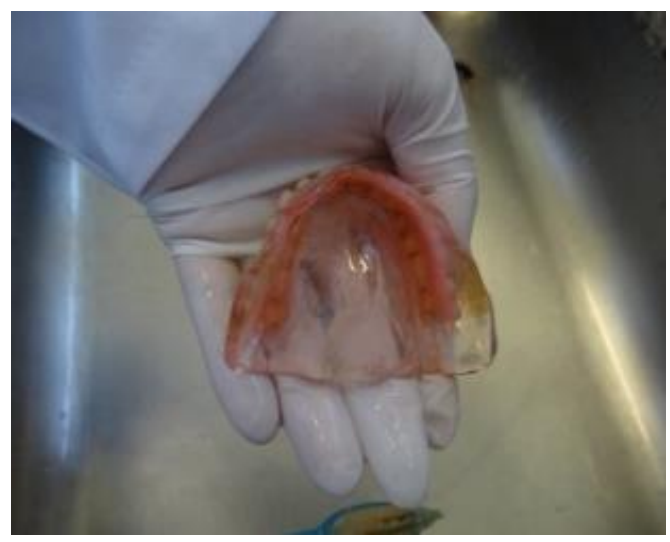

Figura 5. Remoção total do biofilme. 


\subsubsection{Soluções higienizadoras}

Os pacientes foram orientados (APÊNDICE B) a escovar suas próteses com escova específica para próteses totais (Denture - Condor S.A., Santa Catarina, Brasil) e sabonete líquido neutro (JOB Química, Produtos para limpeza Ltda., Monte Alto, SP, Brasil) (Figura 6), os quais foram fornecidos pelos pesquisadores, após as refeições (café da manhã, almoço e jantar) e imersão com ou sem as escovas, após a última escovação, em recipiente contendo um copo (200 mL) das seguintes soluções (Figura 7):

1) Grupo I: Controle: Solução Salina (20 minutos);

2) Grupo II: HS 0,2\%: Solução de Hipoclorito de Sódio 0,20\% (20 minutos) (APÊNDICE C);

3) Grupo III: Efferdent: $200 \mathrm{~mL}$ de água +01 pastilha Efferdent® Power Clean Crystals (MedtechProducts Inc., Irvington, Estados Unidos) (03 minutos);

4) Grupo IV: RC 6,25\%: Solução de Mamona a 6,25\% (Instituto de Química, Universidade de São Paulo, São Carlos, São Paulo, Brasil) (20 minutos).

Os pacientes foram orientados a não dormir com as próteses e, após as imersões, mantêlas imersas em recipiente contendo $200 \mathrm{~mL}$ de água filtrada durante o período noturno. Após o período do sono (noturno), foram orientados a enxaguar as próteses abundantemente por 20 segundos em água corrente, antes de inseri-las na cavidade oral. 


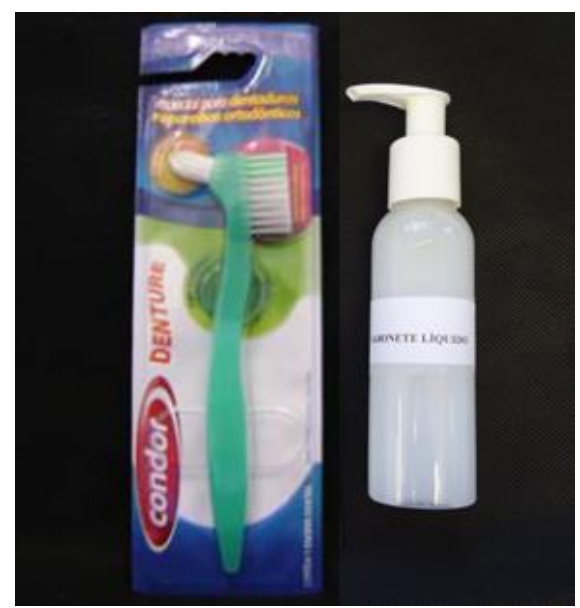

Figura 6. Escova específica e sabonete líquido.

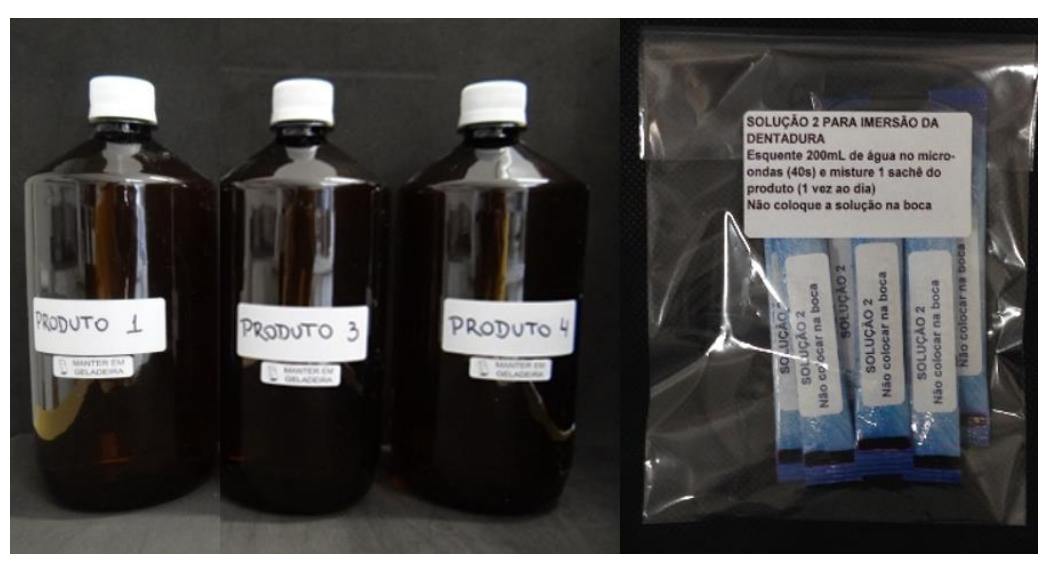

Figura 7. Soluções higienizadoras.

\subsubsection{Período experimental e Delineamento do estudo}

Os métodos químicos de higienização foram aplicados segundo uma configuração do tipo Quadrado latino ou "Latinsquare" (tabela 1), no qual todos os voluntários utilizaram os quatro métodos de higiene propostos, em uma sequência aleatória, por um período de 7 dias cada um. A seleção dos pacientes para imersão das escovas nas soluções também foi realizada de forma randomizada (aleatorizada), para que o processo de distribuição de alocações fosse obtido ao acaso, reduzindo possíveis vieses na comparação das intervenções. A imersão da escova específica para prótese foi realizada por 23 participantes, que foram orientados a imergir as escovas na mesma solução de suas próteses. Os pacientes receberam uma escova para cada solução a ser utilizada, sendo que, ao final de cada solução, as escovas foram recolhidas para análise da presença de unidades formadoras de colônias de Candida spp. e Streptococcus mutans e avaliação da degradação das cerdas das escovas após o protocolo de higienização, de forma qualitativa, por meio de Microscopia Eletrônica de Varredura. 
Tabela 1. Sequência da utilização das soluções segundo configuração Quadrado Latino.

\begin{tabular}{ccccc}
\hline & \multicolumn{4}{c}{ Possíveis ordens } \\
\hline Sequência & I & II & III & IV \\
\hline $\mathbf{1}$ & A & B & C & D \\
2 & B & C & D & A \\
3 & C & D & A & B \\
$\mathbf{4}$ & D & A & B & C \\
\hline
\end{tabular}

Após o período de sete dias, os pacientes retornaram para coleta e quantificação do biofilme, entrega de nova escova, produto e recebimento de instruções (verbal, escrita e com demonstrações) da realização do método seguinte.

Além disso, no intervalo do uso de cada produto, durante uma semana, os pacientes realizaram apenas escovação com sabonete neutro, denominada "wash out", para evitar qualquer efeito residual de um produto, e dessa forma, não interferir no resultado do produto subsequente (efeito "carry-over"). Dessa forma, o período experimental foi de 7 semanas: sete dias para o grupo I; sete dias de wash out; sete dias para o grupo II; sete dias de wash out; sete dias para o grupo III; sete dias de wash out e sete dias para o grupo IV.

\subsubsection{Capacidade de remoção de biofilme}

\subsubsection{Fotografia das próteses}

As próteses foram coradas com Vermelho neutro a 1\%, como descrito anteriormente, posicionadas e fotografadas com uma câmara fotográfica digital (Canon EOS Digital Rebel EFS 18-55, Canon Inc., Tokyo, Japão). A máquina fotográfica foi posicionada na estativa (CS-4 Copy Stand, Testrite Inst. Co., Inc., Newark, New Jersey, Estados Unidos) (Figura 8) com a objetiva voltada para a superfícies internas das próteses. A distância foi determinada pelo foco da região da papila incisiva do palato da prótese superior. Próximo à margem anterior da prótese 
foi posicionada uma régua milimetrada para calibração da unidade de medida $\left(\mathrm{cm}^{2}\right)$ a ser utilizada no software Image Tool® (Windows versão 3.0, The University of Texas Health Science Center, San Antonio, Texas, Estados Unidos), instrumento auxiliar na quantificação do biofilme (Silva-Lovato et al., 2009). As próteses eram fotografadas sobre um campo de papel branco e posicionadas em mesa posicionadora regulável (Figura 9), de forma que foi mantida na mesma posição (inclinação de $30^{\circ}$ ) durante todo o desenvolvimento da pesquisa.

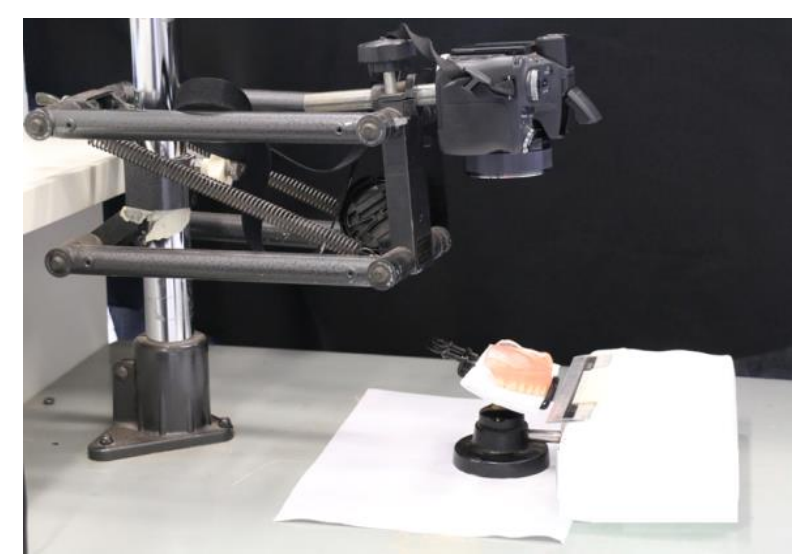

Figura 8. Posicionamento da máquina fotográfica em estativa.

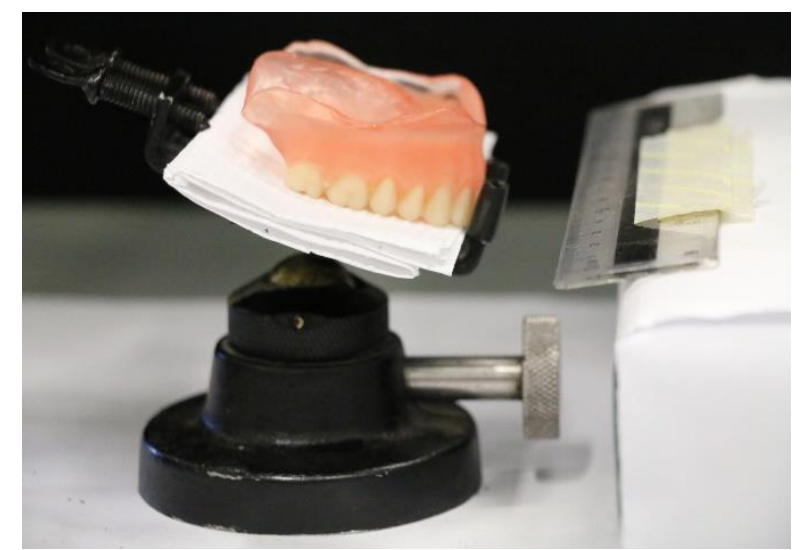

Figura 9. Posicionamento da prótese no dispositivo.

\subsubsection{Quantificação do biofilme}

As fotografias foram transferidas para um computador, processadas (Adobe Photoshop 5.5) e as medidas (área total da superfície interna e corada com biofilme) foram realizadas com o software Image Tool@. Foi realizada a calibração da unidade de medida utilizada no software $\left(\mathrm{cm}^{2}\right)$ (figuras 10 e 11). A delimitação da área total da superfície interna da prótese superior foi realizada, iniciando pela região do freio labial superior (figura 12), partindo para os flancos labial e bucal esquerdo, sulco hamular esquerdo, borda posterior, seguindo pelo sulco hamular direito, flancos bucal e labial direitos até encontrar o ponto inicial da delimitação (figura 13).

As áreas de evidenciação do biofilme da prótese foram medidas uma a uma (figura 14) e registradas em planilhas do software, para ao final, serem somadas e, dessa forma, originarem um valor total referente à área da superfície recoberta pelo biofilme (Silva-Lovato et al., 2009). 

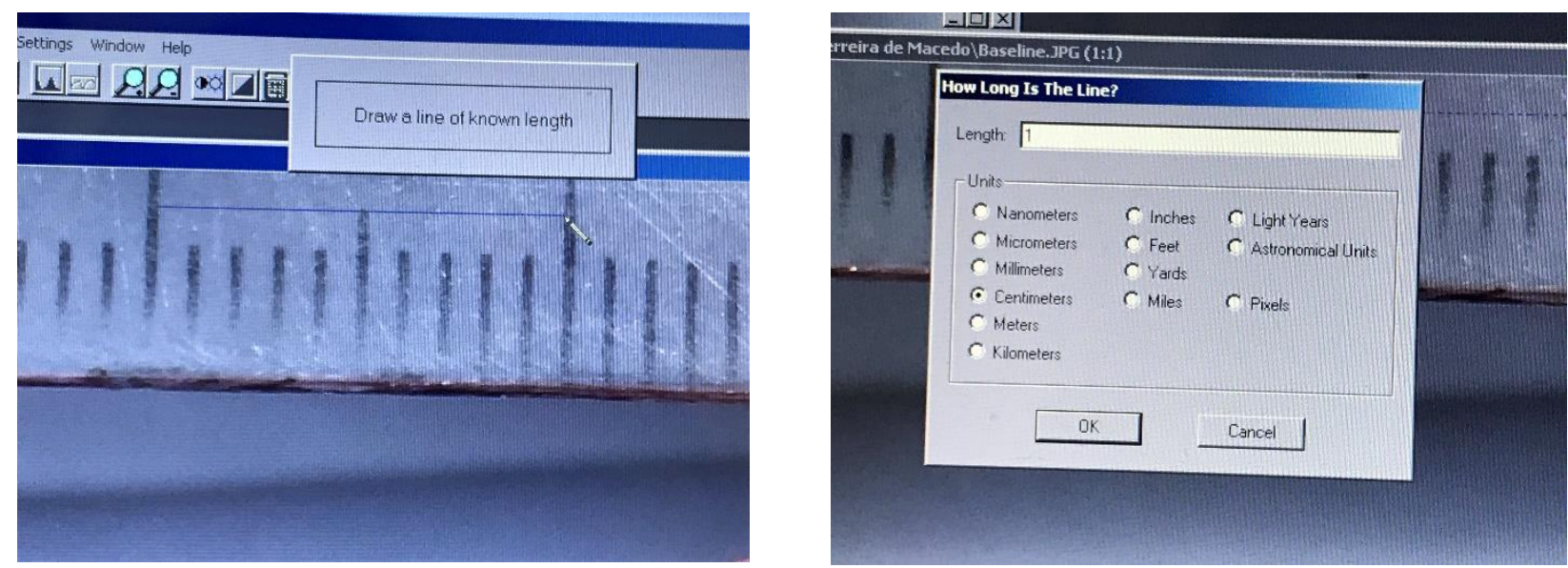

Figuras 10 e 11. Calibração da unidade de medida no software Image Tool®.

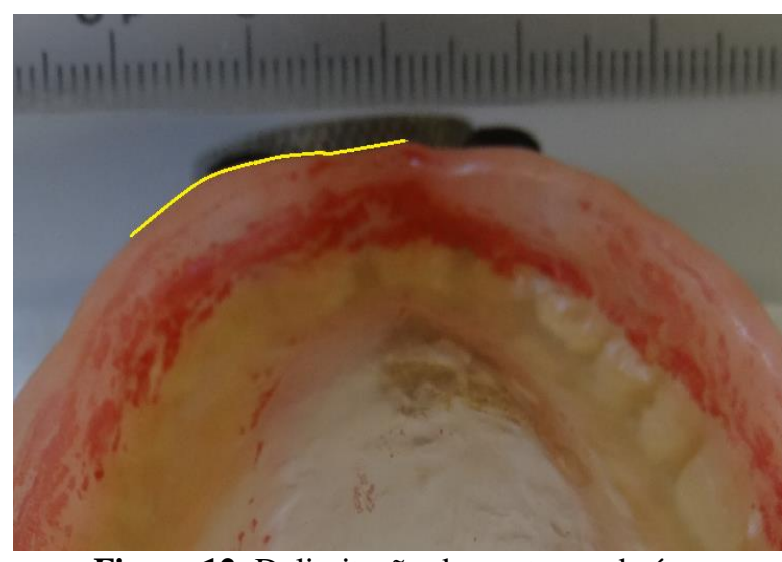

Figura 12. Delimitação do contorno da área total da superfície interna.

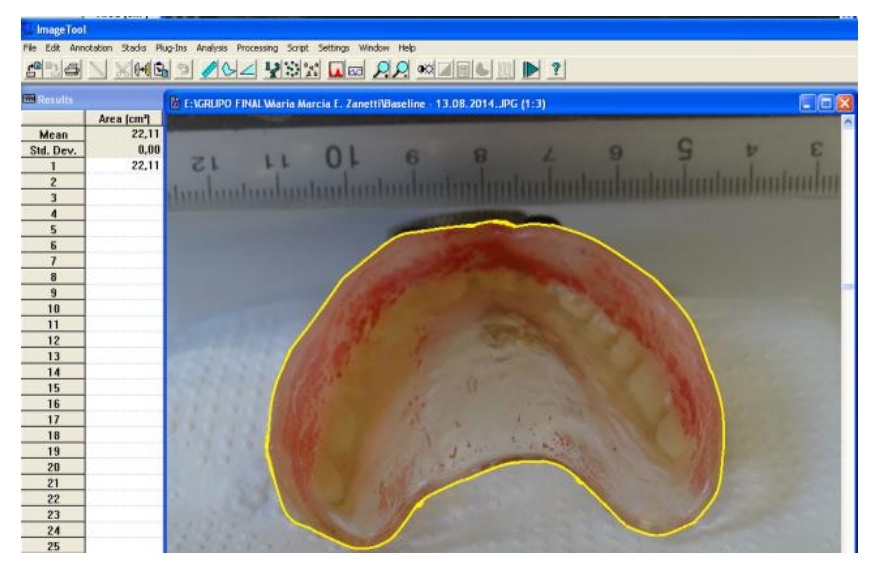

Figura 13. Delimitação final do contorno da área total da prótese superior.

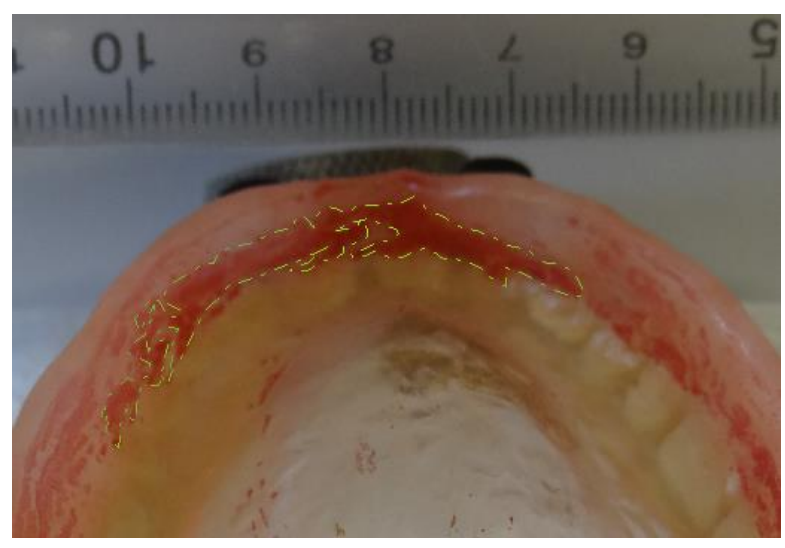

Figura 14. Contorno da área do biofilme. 
Finalizadas as medições das áreas (total e biofilme), a porcentagem da superfície recoberta pelo biofilme $(\mathrm{X})$ foi calculada como sendo a relação entre a área do biofilme multiplicado por 100 e área da superfície total da base interna da prótese.

Área da superfície interna total da prótese $100 \%$

Área da superfície recoberta pelo biofilme $\mathrm{X}$

Logo:

$$
X=\frac{\text { Área da superfície recoberta pelo biofilme } \times 100}{\text { Área da superfície total da base interna da prótese }}
$$

O procedimento descrito foi realizado por um pesquisador não envolvido com o fornecimento das instruções, entrega dos produtos aos pacientes e manuseio das próteses.

\subsubsection{Ação antimicrobiana}

A análise da ação antimicrobiana das soluções foi realizada por meio da contagem de unidades formadoras de colônia (UFC) de Candida spp e S. mutans.

\subsubsection{Coleta microbiológica da prótese total superior}

Após fotografia, cada prótese foi colocada em uma placa de Petri, em capela de fluxo laminar, em zona asséptica. Em seguida, foram adicionados $10 \mathrm{~mL}$ de solução salina sobre a superfície da mesma (figura 15). A prótese foi apreendida por uma pinça esterilizada para fixação e maior eficácia na dessorção do biofilme, em seguida, a prótese foi submetida à escovação da superfície interna, com uma escova dental Tek esterilizada (Johnson \& Johnson do Brasil Indústria e Comércio de Produtos para Saúde Ltda., S. J. dos Campos, SP, Brasil) (figura 16), segundo metodologia descrita por Panzeri, et al. (2009). 


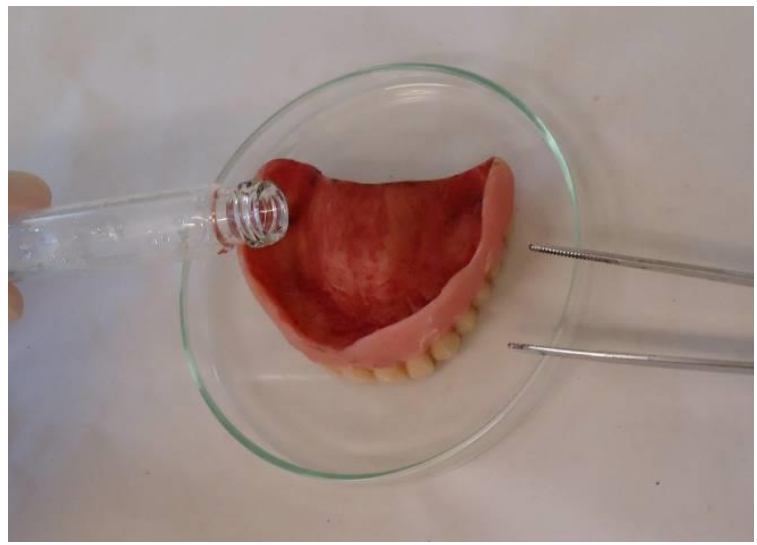

Figura 15. Colocação da solução salina.

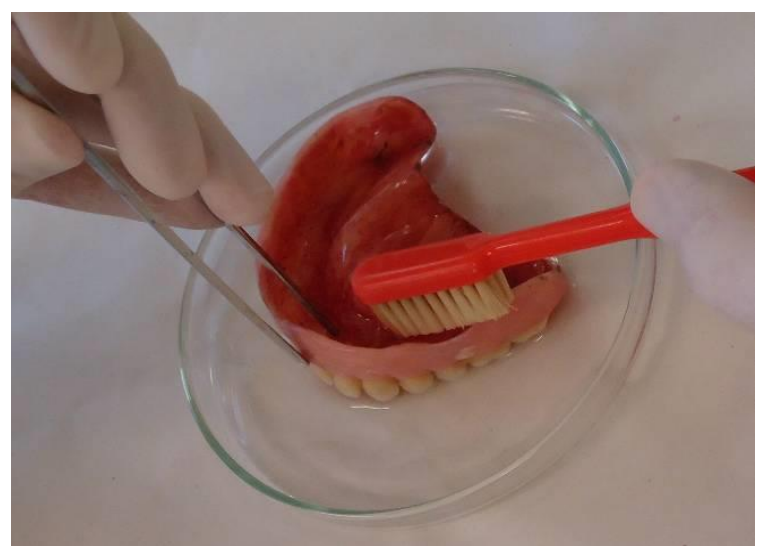

Figura 16. Escovação da superfície interna.

A escovação foi realizada em toda superfície interna da prótese, por dois minutos, atuando sempre com a mesma frequência de movimentos, em condições assépticas. A suspensão obtida foi transferida, com o auxílio de uma pipeta esterilizada (figura 17), para um tubo de ensaio (figuras 18 e 19).

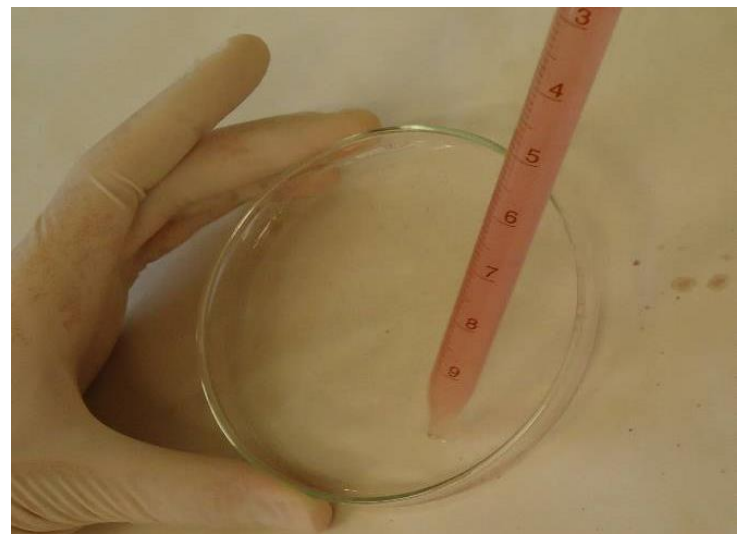

Figura 17. Pipetagem na solução.

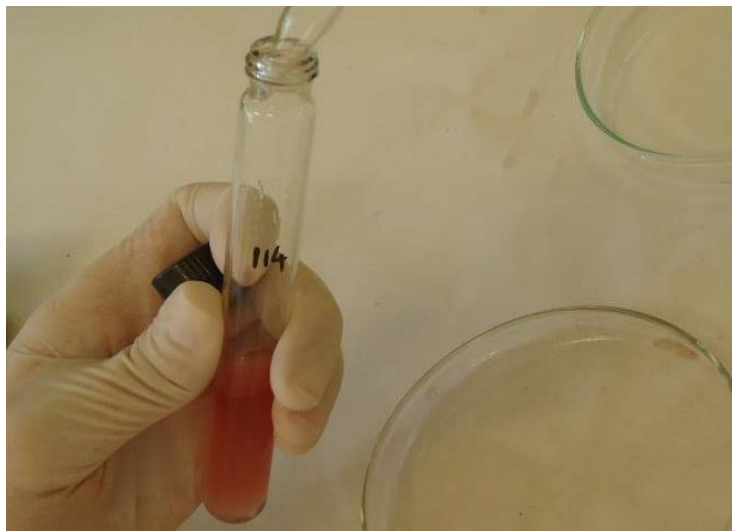

Figura 18. Transferência da solução resultante para o tubo de ensaio.

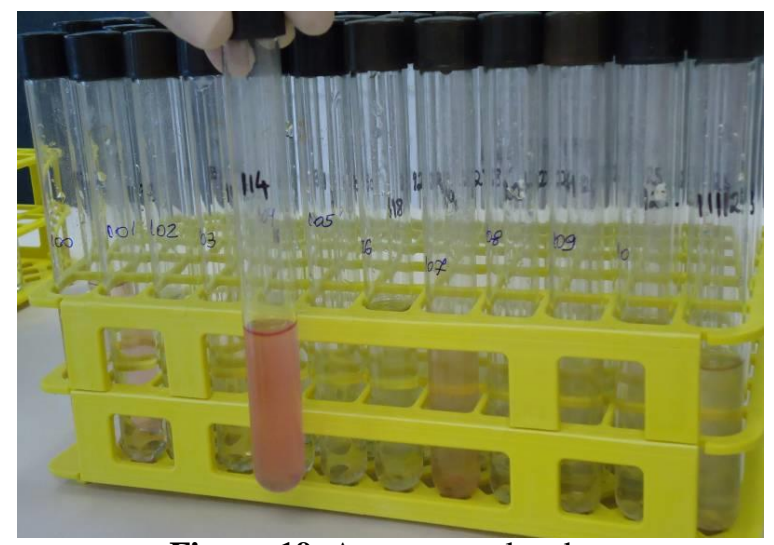

Figura 19. Amostras coletadas. 
A suspensão resultante foi agitada em agitador mecânico (Phoenix®, AP56 Ind. E Com. de Equip. Científicos Ltda., Araraquara, SP, Brasil) por dois minutos e diluições decimais seriadas $\left(10^{0}\right.$ até $\left.10^{3}\right)$ foram obtidas. Alíquotas de $50 \mu \mathrm{L} \mathrm{mL}$ de cada diluição (figura 20 ) foram cultivadas em placas de Petri $(16$ x $60 \mathrm{~mm})$ com meio de cultura específico para Candida spp. (CHROMagar - Difco Laboratories Inc., Detroit, Michigan, EUA) e S. mutans (SB-20 HiMedia Laboratories Pvt. Ltda., Mumbai, India) (figura 21).

Para obtenção do meio CHROMagar, foram dissolvidos 47,7 g do meio de cultura desidratado em 1000,0 mL de água destilada e, o conjunto aquecido até a sua total dissolução, com frequente agitação. Para obtenção do meio SB-20 modificado, foram adicionados 15,0 g de casitona, 5,0 $\mathrm{g}$ de extrato de levedura, 0,2 g de cisteína, 0,1 g de sulfito de sódio, 20,0 g de acetado de sódio, 200,0 g de sacarose em 1000,0 mL de água destilada.

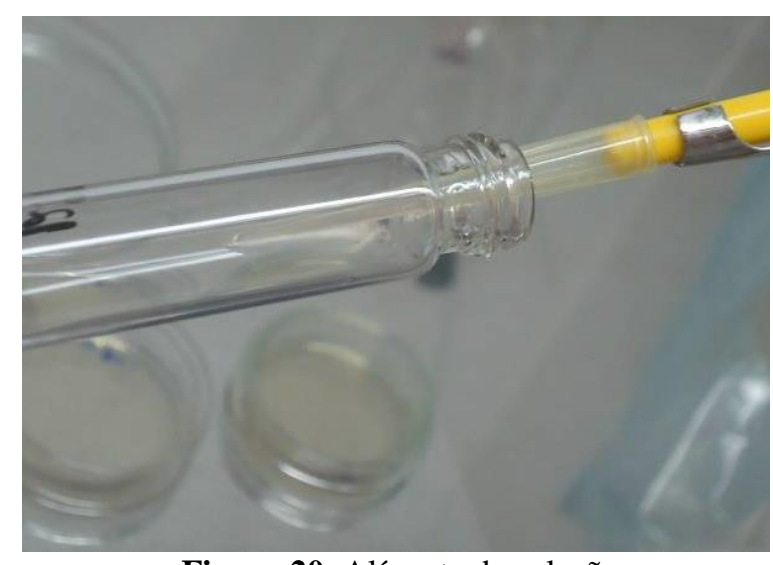

Figura 20. Alíquota da solução.

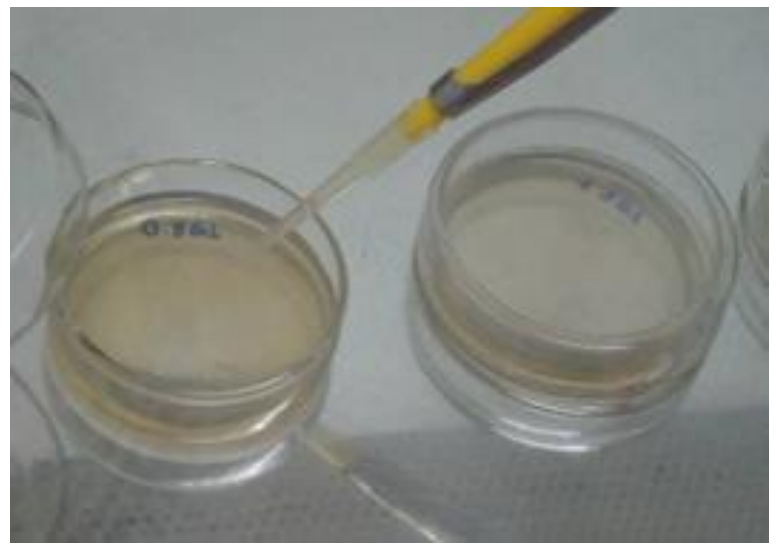

Figura 21. Semeadura em meio de cultura específico.

A incubação foi realizada durante $48 \mathrm{~h}$ a $37^{\circ} \mathrm{C}$. Após esse período, o número de colônias foi contado considerando-se colônias com morfologia típica usando uma lupa estereoscópica (Nikon, modelo 86786, Tóquio, Japão). Para o cálculo de UFC/mL, foi considerada a diluição em que o número de colônias variou entre um e 300 e os valores de UFC/mL foram calculados, utilizando a seguinte fórmula:

\section{$\mathrm{UFC} / \mathrm{mL}=\underline{\mathbf{n}^{0} \text { de colônias } \times 10^{\mathrm{n}}}$}

Sendo: n: valor absoluto da diluição (0, 1, 2 ou 3); q: quantidade, em mL, pipetada para cada diluição quando da semeadura $(0,05 \mathrm{~mL})$. 
As análises do biofilme foram realizadas antes da utilização dos produtos (baseline), ou seja, no primeiro dia do experimento, e após o uso de cada uma das soluções. Após as coletas e após os períodos de wash out, as próteses eram higienizadas pelo pesquisador, como descrito anteriormente, de forma a promover a total remoção do biofilme para assegurar as mesmas condições iniciais de cada produto.

\subsubsection{Coleta microbiológica da escova específica}

Em relação às escovas, os pacientes foram aleatorizados em dois grupos: imersão das escovas juntamente às soluções avaliadas (23 pacientes): total 92 escovas; ou sem imersão das escovas durante o procedimento de higienização (22 pacientes): total 88 escovas; de forma que, para ambos os grupos, cada paciente recebeu uma escova para cada solução $(n=4)$ e uma para o período de wash out $(\mathrm{n}=1)$. Um total de 180 escovas foram avaliadas quanto a capacidade de redução de UFC/mL de Candida spp. e S. mutans, após o uso de cada solução. Além disso, 2 participantes tiveram suas escovas avaliadas por meio de imagens de microscópio eletrônico de varredura (MEV) (EVO 10, Carl Zeiss Microscopy GmbH, Jena, Alemanha).

As escovas eram cortadas sempre no mesmo local (figuras 22 e 23), de forma que o cabo era removido, e depositadas em tubos do tipo falcon contendo $20 \mathrm{~mL}$ de meio de cultura Letheen Broth (figura 24), com o objetivo de neutralizar os agentes antimicrobianos presentes nas soluções higienizadoras utilizadas previamente pelos pacientes.

O conjunto foi levado a uma cuba de ultrassom (figura 25) (Altsonic, Clean 9CA, Ribeirão Preto, São Paulo, Brasil), por 20 minutos, seguido por agitação mecânica (figura 26), para garantir o desprendimento dos micro-organismos resistentes ao procedimento de higiene. Em seguida, os tubos foram centrifugados a $6000 \mathrm{rpm}$, por 7 minutos e o sobrenadante foi descartado. Foi adicionado $1 \mathrm{~mL}$ de solução Phosphate Buffered Saline (PBS) ao pellet, para eluir os micro-organismos. Diluições seriadas $\left(10^{\circ}\right.$ a $\left.10^{-3}\right)$ foram realizadas, de forma que alíquotas de $50 \mu \mathrm{L}$ de cada diluição foram cultivadas em placas de Petri (figura 27) com meio de cultura seletivo para cada micro-organismo: CHROMagar para Candida spp. e SB-20 para S. mutans. Foi realizada incubação $\left(37^{\circ} \mathrm{C}\right.$ por $\left.48 \mathrm{~h}\right)$, e o número de colônias foi contado e os valores de UFC/ml calculados, da mesma forma descrita anteriormente. 


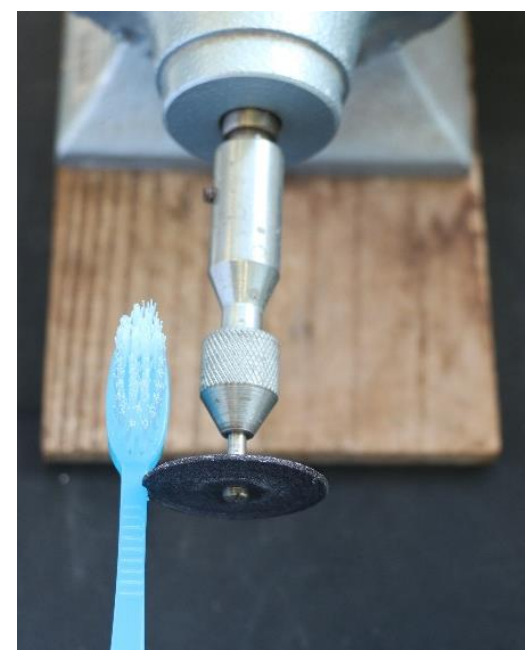

Figura 22. Local do corte na escova.

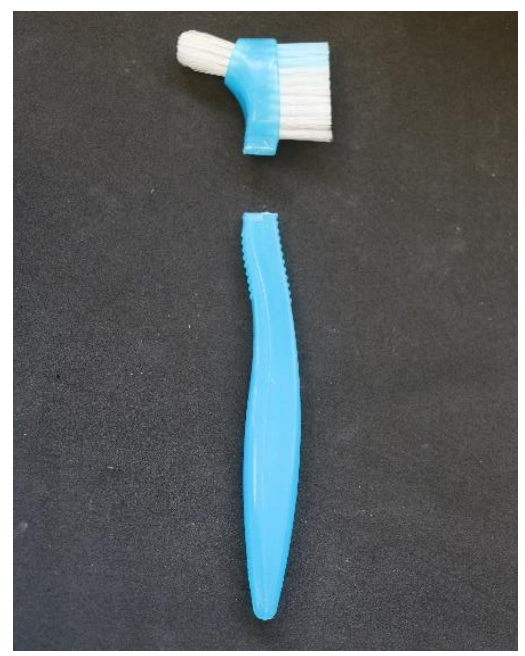

Figura 23. Escova seccionada.

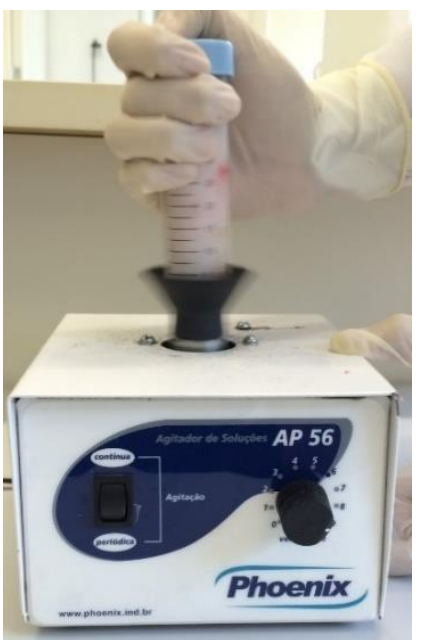

Figura 26. Agitação mecânica.

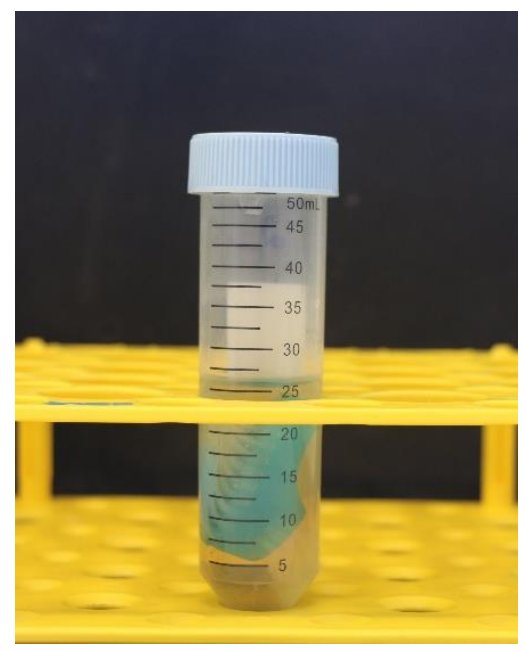

Figura 24. Escova imersa em meio Letheen Broth.

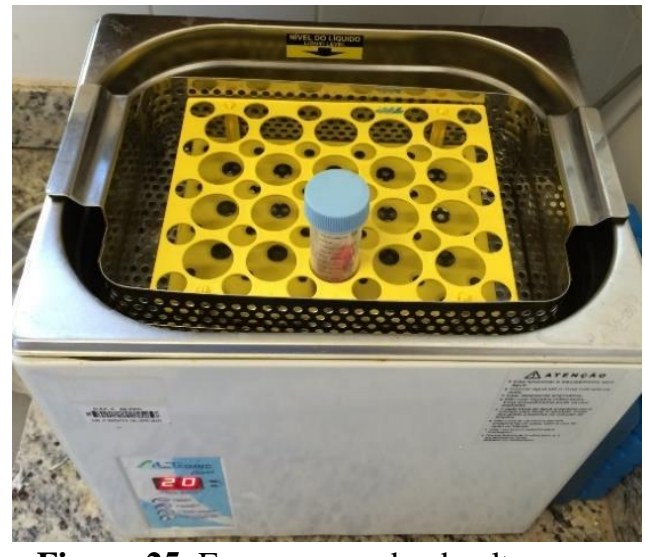

Figura 25. Escova em cuba de ultrassom.

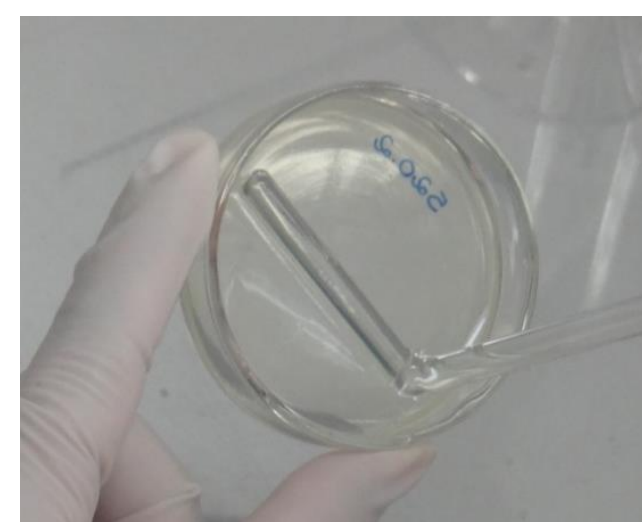

Figura 27. Semeadura em meio de cultura específico.

\subsubsection{Microscópio Eletrônico de Varredura (MEV) - Análise qualitativa}

Para análise da morfologia de superfície das cerdas das escovas, foi empregado microscópio eletrônico de varredura (EVO 10, Carl Zeiss Microscopy GmbH, Jena, Alemanha). Para viabilizar a análise, uma fileira com quatro tufos de cerdas do centro das escovas, foi removida, enquanto as demais cerdas da escova foram utilizadas para a avaliação antimicrobiana. Foi realizado um protocolo de fixação sobre as cerdas com uma solução fixadora de glutaraldeído 2,5\%, por um período de 2 horas. Após a fixação, as cerdas foram 
duas vezes lavadas em solução PBS, por 5 minutos cada. Em seguida, as cerdas foram desidratadas em etanol (30\%, 50\%, 70\%, 90\% e 100\%, 30 minutos cada), e em solução química de hexamethyldisilazane (HMDS) três vezes, por 20 minutos cada. Esse procedimento foi realizado em uma placa para cultura de células de 12 poços (figura 28). As amostras foram mantidas em dessecador de vidro até o momento da análise (figura 29).

Em seguida, as cerdas foram fixadas em stubs, por meio de uma fita condutora adesiva dupla face (Nisshin Em. Co., Ltda., Japão), foram identificadas de acordo com o grupo que pertenciam e submetidas ao processo de metalização (BAL - TEC - Modelo SCD 050, Sputter Coater, Liechtenstein) (figura 30), onde foram sequencialmente posicionadas e recobertas com ouro, através do processo de Sputtering (puverização), por um período de 120 segundos (figura $31)$.

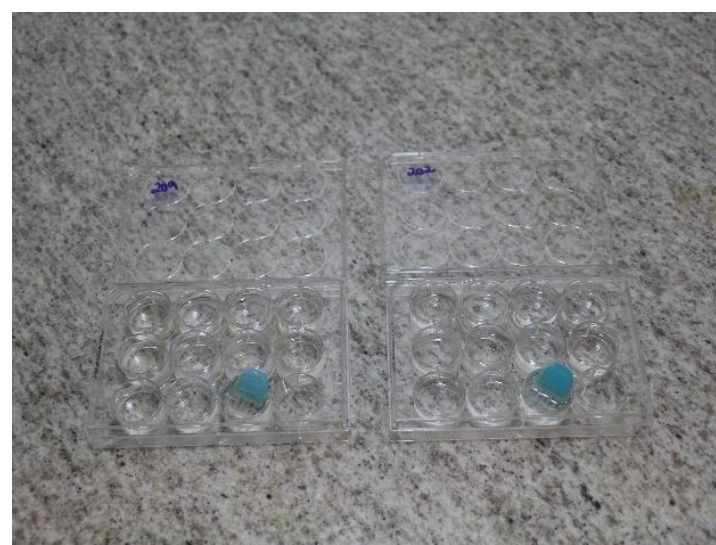

Figura 28. Protocolo de fixação.

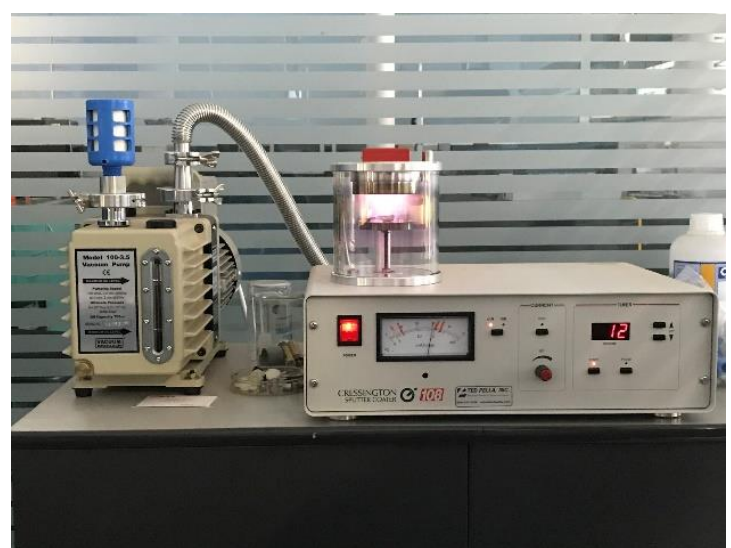

Figura 30. Processo de metalização das cerdas.

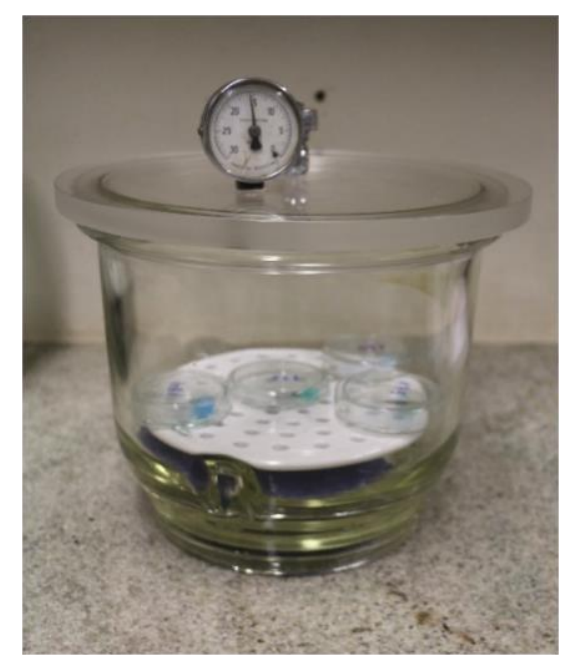

Figura 29. Dessecador de vidro.

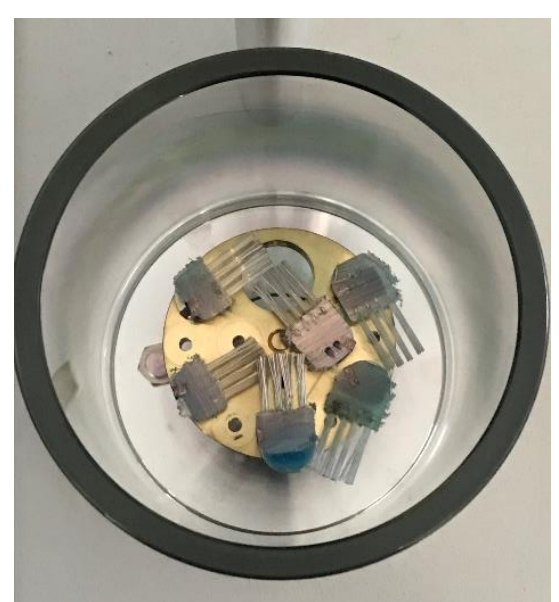

Figura 31. Formação de camada de ouro. 
Finalizada a metalização, as amostras foram acopladas em um dispositivo (figuras 32) para ser posicionado e encaixado no Microscópio Eletrônico de Varredura (Figura 33), para obtenção de imagens das escovas, com aumentos de 1000x e 3500x. Uma análise qualitativa da superfície das cerdas após os protocolos de imersão indicados foi realizada a partir das imagens obtidas.

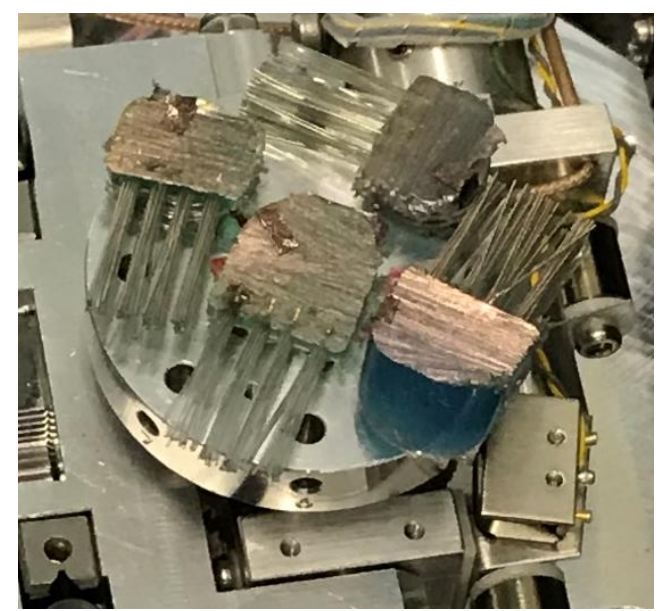

Figura 32. Cerdas acopladas ao dispositivo para análise em MEV.

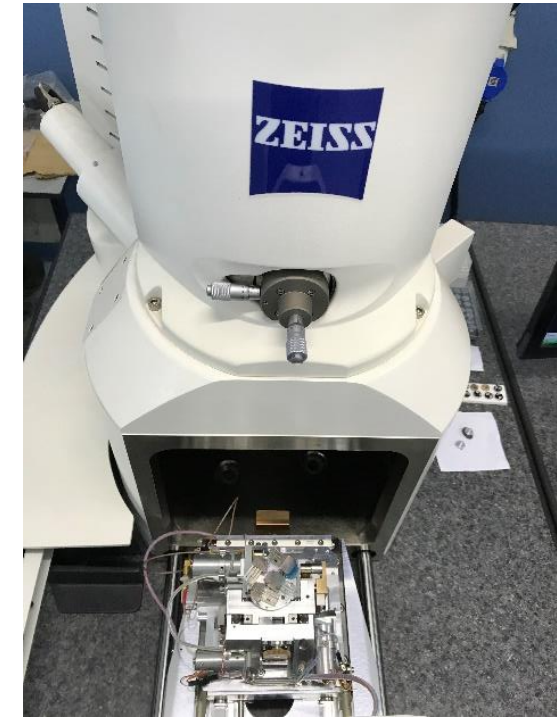

Figura 33. Cerdas posicionadas para análise em MEV.

\subsubsection{Controle de vieses}

Cada participante teve suas próteses submetidas às soluções em sequência aleatória. Um pesquisador (P1), que não se envolveu com as demais fases do projeto, obteve uma lista de números aleatórios gerados por computador, mantidos em segredo até a aplicação das soluções. Um dos pesquisadores (P2) recebeu os números aleatórios e aplicou as soluções em ambiente separado, a fim de que os participantes e avaliadores de desfecho não conhecessem a solução aplicada nas sessões. Os demais pesquisadores foram responsáveis pela aplicação das orientações de higiene (P3), avaliação da área coberta por biofilme e degradação das cerdas das escovas (P4) e análise microbiológica das próteses e escovas (P5). O pesquisador P2 coletou as informações das variáveis e codificou os tratamentos como aleatoriamente "1", "2", "3" e "4" (número gerado por computador) e os encaminhou para P1, que realizou a análise estatística dos resultados. Dessa forma, os participantes e a maioria dos pesquisadores permaneceram cegos às soluções aplicadas. 


\subsubsection{Análise estatística}

Os valores obtidos das análises foram submetidos a testes estatísticos com o auxílio do programa estatístico (SPSS 12.0.0 for Windows; SPSS Inc, Chicago, Ill, USA) em microcomputador (Intel - S775 P4 5112.8 1M/533hz). Os dados não aderiram à distribuição normal, conforme averiguado pelo teste de Kolmogorov-Smirnov.

Sendo assim, para a análise da diferença entre o protocolo de imersão ou não da escova, foi utilizado o teste de Mann-Whitney $(\alpha=0,05)$. Para a análise da ação das soluções frente a remoção de biofilme e ação antimicrobiana foi utilizado o teste de Friedman, seguido pelo pós teste de Wilcoxon $(\alpha=0,05)$. 
5. Resultados 



\subsection{ANÁLISE CLÍNICA}

Sessenta e quatro pacientes iniciaram tratamento na Clínica de Prótese Total e foram convidados a participar da pesquisa (triagem). Desses, 9 pacientes foram excluídos da amostra por não usarem próteses totais superiores, 3 se recusaram a participar da pesquisa, 1 não compareceu corretamente aos retornos agendados devido a problemas de saúde, 2 pacientes abandonaram a pesquisa e 4 pacientes foram retirados da pesquisa devido ao uso inadequado das soluções. Assim, a amostra final deste estudo, foi de 45 pacientes (Figura 34).

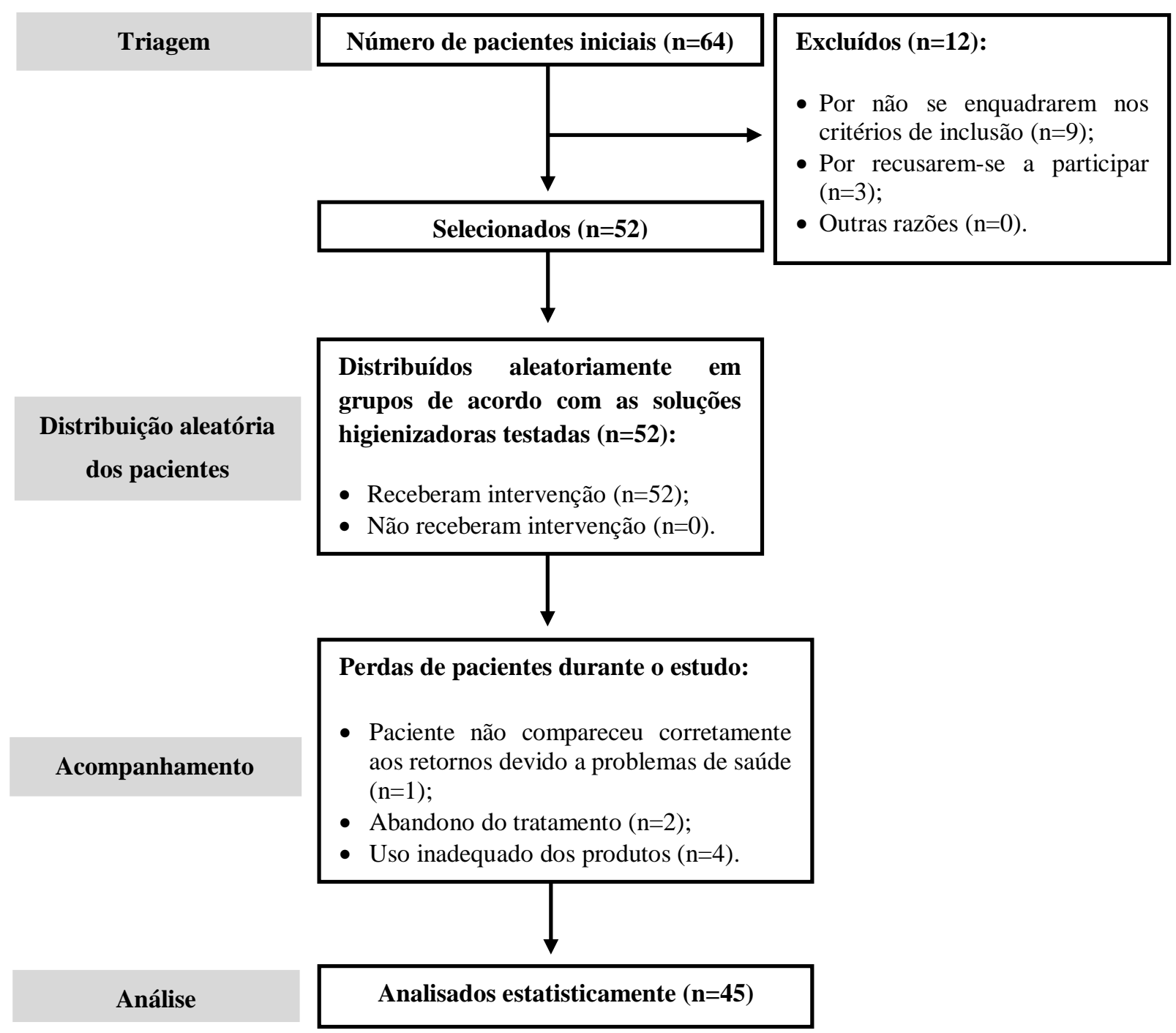

Figura 34. Fluxograma dos participantes (adaptado da declaração CONSORT). 


\subsubsection{Capacidade de Remoção de Biofilme}

Os resultados originais das áreas (total e biofilme) no baseline e após o uso das soluções estão apresentados no Apêndice D (tabela D). As porcentagens de biofilme obtidas estão apresentadas na tabela 2. A figura 35 mostra a área coberta por biofilme em porcentagem para cada tratamento testado, para todos os pacientes.

Tabela 2. Porcentagens de biofilme após cada intervenção.

\begin{tabular}{ccccccc}
\hline Pacientes & Imersão & Baseline & Controle & HS 0,2\% & Efferdent & RC 6,25\% \\
\hline $\mathbf{1}$ & Não & 27,90 & 16,47 & 12,96 & 3,46 & 5,75 \\
$\mathbf{2}$ & Não & 2,69 & 3,78 & 0,00 & 3,20 & 0,00 \\
$\mathbf{3}$ & Não & 22,60 & 36,88 & 0,63 & 3,65 & 1,93 \\
$\mathbf{4}$ & Não & 0,23 & 4,26 & 0,00 & 0,14 & 16,02 \\
$\mathbf{5}$ & Não & 1,26 & 4,21 & 0,00 & 1,82 & 0,56 \\
$\mathbf{6}$ & Não & 20,56 & 24,10 & 10,52 & 13,95 & 24,24 \\
$\mathbf{7}$ & Não & 53,41 & 38,55 & 0,00 & 9,15 & 16,08 \\
$\mathbf{8}$ & Não & 23,66 & 30,46 & 45,83 & 9,85 & 32,44 \\
$\mathbf{9}$ & Não & 4,30 & 0,86 & 0,00 & 0,39 & 0,00 \\
$\mathbf{1 0}$ & Não & 27,42 & 19,02 & 9,17 & 7,43 & 14,17 \\
$\mathbf{1 1}$ & Não & 3,75 & 4,48 & 2,72 & 2,14 & 3,04 \\
$\mathbf{1 2}$ & Não & 8,17 & 17,33 & 0,77 & 0,00 & 5,71 \\
$\mathbf{1 3}$ & Não & 19,15 & 8,40 & 0,00 & 6,75 & 5,95 \\
$\mathbf{1 4}$ & Não & 41,76 & 22,46 & 11,26 & 12,22 & 15,41 \\
$\mathbf{1 5}$ & Não & 3,96 & 5,98 & 0,00 & 0,00 & 0,29 \\
$\mathbf{1 6}$ & Não & 30,57 & 24,72 & 0,00 & 5,32 & 11,88 \\
$\mathbf{1 7}$ & Não & 11,30 & 10,17 & 0,00 & 6,70 & 7,67 \\
$\mathbf{1 8}$ & Não & 28,79 & 24,68 & 1,14 & 23,42 & 10,38 \\
$\mathbf{1 9}$ & Não & 23,44 & 7,13 & 0,00 & 10,80 & 2,56 \\
$\mathbf{2 0}$ & Não & 15,64 & 9,75 & 0,24 & 4,24 & 5,39 \\
$\mathbf{2 1}$ & Não & 38,14 & 17,22 & 0,00 & 1,20 & 14,35 \\
$\mathbf{2 2}$ & Não & 30,09 & 24,03 & 0,00 & 3,39 & 3,21 \\
$\mathbf{2 3}$ & Sim & 2,23 & 3,65 & 0,00 & 0,00 & 2,07 \\
$\mathbf{2 4}$ & Sim & 6,58 & 4,88 & 0,93 & 4,75 & 2,73 \\
$\mathbf{2 5}$ & Sim & 14,97 & 16,10 & 0,00 & 2,01 & 4,84 \\
$\mathbf{2 6}$ & Sim & 9,62 & 17,28 & 0,00 & 8,36 & 5,09 \\
$\mathbf{2 7}$ & Sim & 10,55 & 8,34 & 8,38 & 4,67 & 10,30 \\
$\mathbf{2 8}$ & Sim & 18,08 & 15,75 & 5,36 & 8,09 & 9,35 \\
\hline
\end{tabular}

HS: Hipoclorito de Sódio; RC: Ricinus communis. 
Tabela 2 (Continuação). Porcentagens de biofilme após cada intervenção.1 (Continuação). Porcentagens de biofilme após cada intervenção.

\begin{tabular}{ccccccc}
\hline Pacientes & Imersão & Baseline & Controle & HS 0,2\% & Efferdent & RC 6,25\% \\
\hline $\mathbf{2 9}$ & Sim & 67,25 & 9,99 & 27,51 & 13,75 & 6,39 \\
$\mathbf{3 0}$ & Sim & 12,53 & 3,05 & 1,49 & 2,90 & 2,25 \\
$\mathbf{3 1}$ & Sim & 14,98 & 5,97 & 0,18 & 0,64 & 3,24 \\
$\mathbf{3 2}$ & Sim & 13,86 & 10,86 & 4,49 & 5,87 & 5,72 \\
$\mathbf{3 3}$ & Sim & 24,81 & 15,24 & 6,58 & 12,21 & 6,80 \\
$\mathbf{3 4}$ & Sim & 47,56 & 44,37 & 12,45 & 45,34 & 47,06 \\
$\mathbf{3 5}$ & Sim & 17,58 & 8,49 & 0,67 & 4,08 & 4,61 \\
$\mathbf{3 6}$ & Sim & 9,15 & 12,18 & 8,08 & 10,84 & 8,62 \\
$\mathbf{3 7}$ & Sim & 28,98 & 19,38 & 17,01 & 12,87 & 14,84 \\
$\mathbf{3 8}$ & Sim & 62,04 & 49,59 & 8,47 & 10,39 & 10,40 \\
$\mathbf{3 9}$ & Sim & 9,90 & 7,59 & 6,04 & 6,68 & 6,43 \\
$\mathbf{4 0}$ & Sim & 43,89 & 37,94 & 20,87 & 34,28 & 33,78 \\
$\mathbf{4 1}$ & Sim & 38,03 & 30,22 & 21,35 & 21,20 & 22,92 \\
$\mathbf{4 2}$ & Sim & 44,02 & 33,50 & 17,88 & 20,77 & 21,51 \\
$\mathbf{4 3}$ & Sim & 36,41 & 29,32 & 22,48 & 24,14 & 19,53 \\
$\mathbf{4 4}$ & Sim & 25,25 & 17,85 & 0,00 & 3,24 & 3,01 \\
$\mathbf{4 5}$ & Sim & 63,23 & 51,52 & 6,21 & 11,37 & 41,98 \\
\hline
\end{tabular}

HS: Hipoclorito de Sódio; RC: Ricinus communis.

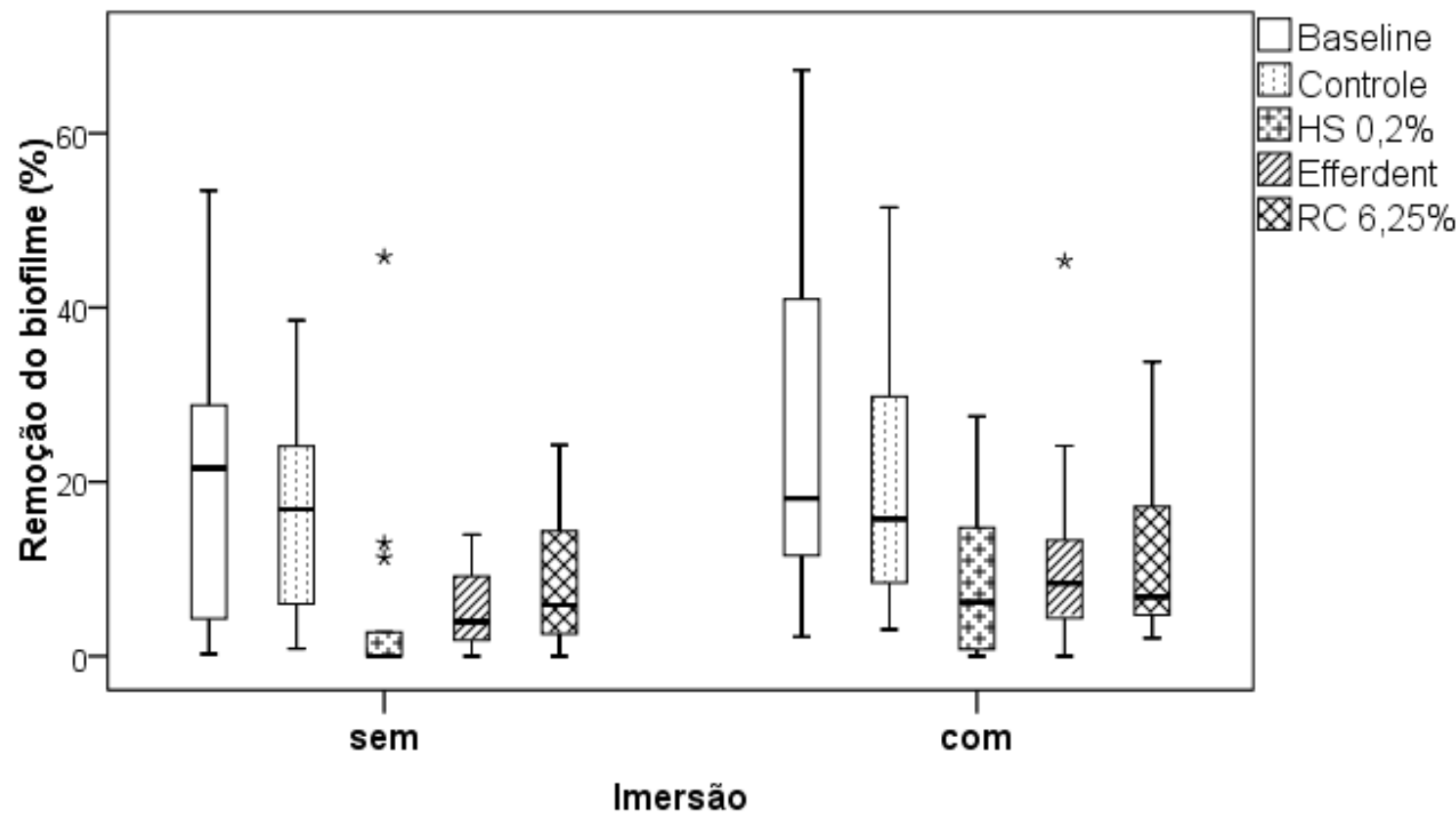

Figura 35: Box-plot da área coberta por biofilme em porcentagem - Pacientes com e sem imersão da escova nas soluções. 
A partir do teste de Friedman, observou-se diferença significante entre as soluções ( $\mathrm{p}<0,001)$. A Tabela 3 mostra os postos médios obtidos pelo teste, bem como os resultados das comparações múltiplas.

Tabela 3. Postos médios (PM), resultados do teste de Friedman e comparações múltiplas - Propriedade de Remoção de Biofilme.

\begin{tabular}{ccccc} 
Soluções & \multicolumn{2}{c}{ Sem imersão da escova } & \multicolumn{2}{c}{ Com imersão da escova } \\
\cline { 2 - 5 } & PM & Fr (P-Valor) & PM & Fr (P-Valor) \\
\cline { 2 - 5 } & $4,32^{\mathrm{A}}$ & & $4,78^{\mathrm{A}}$ & \\
Baseline & $4,18^{\mathrm{A}}$ & & $3,91^{\mathrm{A}}$ & 65,89 \\
Solução salina (controle) & $1,48^{\mathrm{B}}$ & 53,75 & $1,41^{\mathrm{B}}$ & $(<0,001)^{*}$ \\
Hipoclorito de sódio 0,2\% & $2,25^{\mathrm{B}}$ & $(<0,001)^{*}$ & $2,41^{\mathrm{B}}$ & \\
Efferdent & $2,77^{\mathrm{B}}$ & & $2,48^{\mathrm{B}}$ & \\
Ricinus communis 6,25\% & & & \\
\hline
\end{tabular}

*Diferença significante $(\mathrm{P}<0,05)$. Comparação entre pares: letras distintas indicam diferença significante.

Os resultados mostraram que, em relação à propriedade de remoção de biofilme, em ambos os grupos (com e sem imersão da escova), as soluções testadas foram eficazes e semelhantes, sendo diferentes da solução controle que apresentou porcentagem de biofilme semelhante ao baseline.

\subsubsection{Ação Antimicrobiana}

\subsubsection{Prótese}

Os dados originais da contagem total de UFC/mL de Candida spp. e $S$. mutans estão apresentados no Apêndice E (tabelas E1 e E2, respectivamente). A tabela 4 mostra as leituras do total de UFC/mL presentes nas próteses superiores, após transformação em log $(\mathrm{UFC}+1)$, de Candida spp. no baseline e após o uso de cada uma das soluções higienizadoras. A figura 36 mostra o box-plot de UFC/mL obtidos, transformados em log (UFC+1), para Candida spp.. 
Tabela 4. Total de UFC/mL, em log (UFC/mL+1), de Candida spp.

\begin{tabular}{|c|c|c|c|c|c|c|}
\hline Pacientes & Imersão & Baseline & Controle & HS 0,2\% & Efferdent & RC 6,25\% \\
\hline 1 & Não & 0,00 & 2,38 & 4,27 & 0,00 & 3,12 \\
\hline 2 & Não & 3,93 & 3,90 & 0,00 & 4,65 & 3,33 \\
\hline 3 & Não & 4,32 & 3,26 & 0,00 & 0,00 & 0,00 \\
\hline 4 & Não & 0,00 & 0,00 & 0,00 & 0,00 & 4,00 \\
\hline 5 & Não & 1,32 & 1,79 & 0,00 & 0,00 & 0,00 \\
\hline 6 & Não & 2,30 & 0,00 & 0,00 & 0,00 & 0,00 \\
\hline 7 & Não & 4,75 & 2,30 & 0,00 & 0,00 & 1,32 \\
\hline 8 & Não & 4,32 & 5,00 & 5,37 & 5,31 & 4,23 \\
\hline 9 & Não & 5,26 & 4,30 & 0,00 & 4,58 & 0,00 \\
\hline 10 & Não & 3,98 & 3,34 & 2,59 & 2,81 & 0,00 \\
\hline 11 & Não & 3,08 & 2,88 & 0,00 & 0,00 & 0,00 \\
\hline 12 & Não & 5,57 & 5,45 & 0,00 & 0,00 & 4,90 \\
\hline 13 & Não & 4,85 & 5,08 & 0,00 & 0,00 & 4,51 \\
\hline 14 & Não & 6,31 & 5,72 & 2,08 & 3,34 & 5,48 \\
\hline 15 & Não & 3,90 & 3,90 & 0,00 & 0,00 & 3,83 \\
\hline 16 & Não & 5,61 & 0,00 & 0,00 & 6,44 & 5,12 \\
\hline 17 & Não & 5,20 & 2,45 & 1,32 & 2,45 & 4,51 \\
\hline 18 & Não & 2,53 & 0,00 & 1,32 & 0,00 & 0,00 \\
\hline 19 & Não & 4,53 & 0,00 & 0,00 & 3,46 & 5,11 \\
\hline 20 & Não & 4,09 & 0,00 & 0,00 & 0,00 & 0,00 \\
\hline 21 & Não & 5,64 & 1,79 & 0,00 & 2,78 & 5,51 \\
\hline 22 & Não & 6,08 & 4,91 & 0,00 & 0,00 & 0,00 \\
\hline 23 & Sim & 0,00 & 2,38 & 4,27 & 0,00 & 3,12 \\
\hline 24 & Sim & 2,62 & 0,00 & 0,00 & 0,00 & 0,00 \\
\hline 25 & Sim & 3,05 & 1,32 & 0,00 & 0,00 & 0,00 \\
\hline 26 & Sim & 3,16 & 0,00 & 0,00 & 0,00 & 0,00 \\
\hline 27 & Sim & 2,98 & 0,00 & 0,00 & 0,00 & 0,00 \\
\hline 28 & Sim & 2,66 & 2,60 & 0,00 & 0,00 & 0,00 \\
\hline 29 & Sim & 1,32 & 0,00 & 0,00 & 0,00 & 0,00 \\
\hline 30 & Sim & 5,20 & 4,70 & 0,00 & 3,60 & 3,41 \\
\hline 31 & Sim & 4,04 & 4,67 & 0,00 & 3,46 & 3,36 \\
\hline 32 & Sim & 2,49 & 1,95 & 0,00 & 0,00 & 0,00 \\
\hline 33 & Sim & 2,30 & 2,05 & 0,00 & 0,00 & 0,00 \\
\hline 34 & Sim & 4,53 & 4,36 & 0,00 & 0,00 & 3,20 \\
\hline 35 & Sim & 5,40 & 5,36 & 4,39 & 5,09 & 4,32 \\
\hline 36 & Sim & 3,97 & 4,39 & 0,00 & 0,00 & 0,00 \\
\hline 37 & Sim & 4,54 & 2,95 & 2,51 & 2,15 & 2,60 \\
\hline 38 & Sim & 4,51 & 4,44 & 3,85 & 4,24 & 4,21 \\
\hline 39 & Sim & 5,66 & 0,00 & 0,00 & 0,00 & 3,02 \\
\hline 40 & Sim & 4,03 & 4,01 & 4,28 & 0,00 & 0,00 \\
\hline
\end{tabular}

HS: Hipoclorito de Sódio; RC: Ricinus communis. 
Tabela 4 (continuação). Total de UFC/mL, em log (UFC/mL+1), de Candida spp.

\begin{tabular}{ccccccc}
\hline Pacientes & Imersão & Baseline & Controle & HS 0,2 \% & Efferdent & RC 6,25\% \\
\hline $\mathbf{4 1}$ & Sim & 2,90 & 4,20 & 0,00 & 2,91 & 2,89 \\
$\mathbf{4 2}$ & Sim & 5,81 & 4,98 & 2,88 & 1,79 & 2,78 \\
$\mathbf{4 3}$ & Sim & 2,08 & 0,00 & 1,32 & 0,00 & 0,00 \\
$\mathbf{4 4}$ & Sim & 5,25 & 0,00 & 2,73 & 0,00 & 0,00 \\
$\mathbf{4 5}$ & Sim & 6,12 & 4,49 & 0,00 & 0,00 & 3,53 \\
\hline
\end{tabular}

HS: Hipoclorito de Sódio; RC: Ricinus communis.

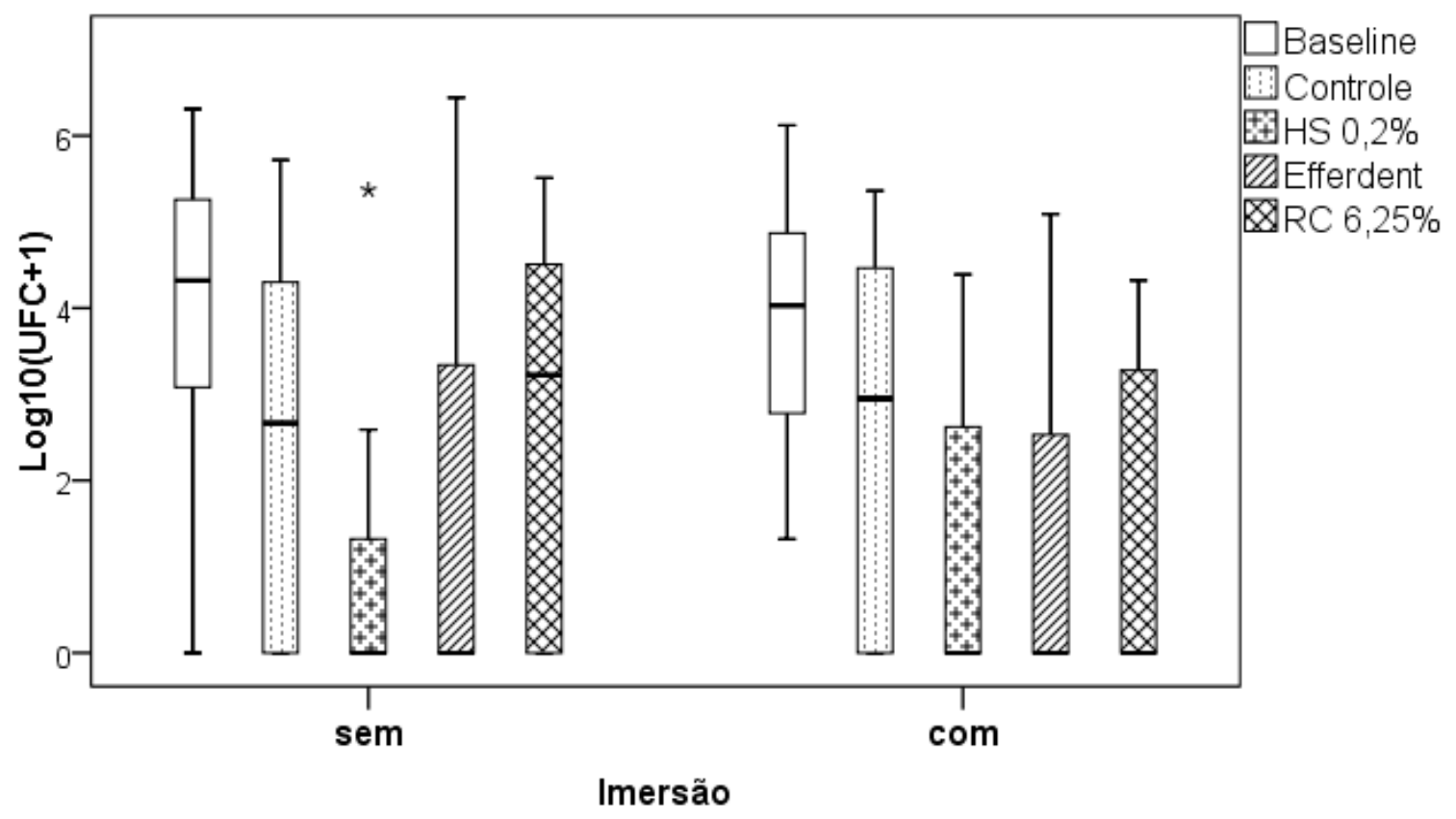

Figura 36: Box-plot de UFC/mL de Candida spp. após transformação em log10(UFC+1).

A partir do teste de Friedman, observou-se diferença significante entre as soluções ( $\mathrm{p}<0,001)$. A Tabela 5 contém os postos médios obtidos pelo teste, bem como os resultados das comparações múltiplas. 
Tabela 5. Postos médios (PM) e resultados do teste de Friedman seguido por comparações múltiplas para os resultados da ação antimicrobiana da Candida spp.

\begin{tabular}{ccccc}
\hline \multirow{2}{*}{ Soluções } & \multicolumn{2}{c}{ Sem imersão da escova } & \multicolumn{2}{c}{ Com imersão da escova } \\
\cline { 2 - 5 } & \multicolumn{1}{c}{ PM } & Fr (P-Valor) & PM & Fr (P-Valor) \\
\hline Baseline & $4,34^{\mathrm{A}}$ & & $4,74^{\mathrm{A}}$ & \\
Solução salina (controle) & $3,25^{\mathrm{AB}}$ & 29,92 & $3,61^{\mathrm{A}}$ & 57,53 \\
Hipoclorito de sódio 0,2\% & $2,09^{\mathrm{B}}$ & $(<0,001)^{*}$ & $2,22^{\mathrm{B}}$ & $(<0,001)^{*}$ \\
Efferdent & $2,57^{\mathrm{B}}$ & & $2,24^{\mathrm{B}}$ & \\
Ricinus communis 6,25\% & $2,75^{\mathrm{B}}$ & & $2,20^{\mathrm{B}}$ & \\
\hline
\end{tabular}

"Diferença significante $(\mathrm{P}<0,05)$. Comparação entre pares: letras distintas indicam diferença significante.

Todas as soluções testadas apresentaram ação antimicrobiana frente Candida spp. em ambos os grupos. Para o grupo de pacientes que não fizeram a imersão da escova nas soluções, a solução controle apresentou valores intermediários, enquanto que para os que realizaram tal procedimento, não houve diferença significante entre Baseline e Controle $(\mathrm{p}=0,153)$.

A tabela 6 mostra as leituras do total de UFC/mL presentes nas próteses superiores, após transformação em $\log (\mathrm{UFC}+1)$, de $S$. mutans, no baseline e após o uso de cada uma das soluções higienizadoras. A figura 37 mostra o box-plot de UFC/mL obtidos, transformados em $\log$ (UFC+1), para S. muntans.

Tabela 6. Total de UFC/mL, em log (UFC/mL+1), de S. mutans.

\begin{tabular}{ccrrrrr}
\hline Pacientes & Imersão & Baseline & Controle & HS 0,2\% & Efferdent & RC 6,25\% \\
\hline $\mathbf{1}$ & Não & 2,38 & 0,00 & 0,00 & 0,00 & 0,00 \\
$\mathbf{2}$ & Não & 1,91 & 2,21 & 0,00 & 0,00 & 0,00 \\
$\mathbf{3}$ & Não & 3,30 & 0,00 & 0,00 & 0,00 & 0,00 \\
$\mathbf{4}$ & Não & 0,00 & 0,00 & 0,00 & 0,00 & 0,00 \\
$\mathbf{5}$ & Não & 0,00 & 0,00 & 0,00 & 0,00 & 0,00 \\
$\mathbf{6}$ & Não & 6,31 & 4,08 & 0,00 & 0,00 & 3,20 \\
$\mathbf{7}$ & Não & 6,48 & 3,83 & 0,00 & 0,00 & 0,00 \\
$\mathbf{8}$ & Não & 3,58 & 0,00 & 0,00 & 0,00 & 2,00 \\
$\mathbf{9}$ & Não & 5,56 & 4,01 & 0,00 & 2,97 & 0,00 \\
$\mathbf{1 0}$ & Não & 4,65 & 4,73 & 2,68 & 2,66 & 4,01 \\
$\mathbf{1 1}$ & Não & 6,59 & 5,11 & 0,00 & 0,00 & 0,00 \\
$\mathbf{1 2}$ & Não & 5,44 & 5,42 & 0,00 & 0,00 & 4,92 \\
$\mathbf{1 3}$ & Não & 5,86 & 5,32 & 0,00 & 2,90 & 5,75 \\
$\mathbf{1 4}$ & Não & 7,31 & 6,15 & 0,00 & 0,00 & 0,00 \\
\hline
\end{tabular}

HS: Hipoclorito de Sódio; RC: Ricinus communis. 
Tabela 6 (Continuação). Total de UFC/mL, em $\log (\mathrm{UFC} / \mathrm{mL}+1)$, de S. mutans.

\begin{tabular}{|c|c|c|c|c|c|c|}
\hline Pacientes & Imersão & Baseline & Controle & HS 0,2\% & Efferdent & $\mathrm{RC} 6,25 \%$ \\
\hline 15 & Não & 5,47 & 3,38 & 0,00 & 0,00 & 0,00 \\
\hline 16 & Não & 6,83 & 5,93 & 0,00 & 0,00 & 5,12 \\
\hline 17 & Não & 5,26 & 6,03 & 0,00 & 2,15 & 0,00 \\
\hline 18 & Não & 3,06 & 3,47 & 2,15 & 0,00 & 3,74 \\
\hline 19 & Não & 6,64 & 2,98 & 2,08 & 6,53 & 6,26 \\
\hline 20 & Não & 2,94 & 2,05 & 0,00 & 0,00 & 2,94 \\
\hline 21 & Não & 6,03 & 7,16 & 1,32 & 2,15 & 2,08 \\
\hline 22 & Não & 6,59 & 5,32 & 0,00 & 0,00 & 0,00 \\
\hline 23 & Sim & 2,45 & 0,00 & 0,00 & 1,61 & 0,00 \\
\hline 24 & Sim & 1,79 & 0,00 & 0,00 & 0,00 & 1,32 \\
\hline 25 & Sim & 5,32 & 3,08 & 0,00 & 1,32 & 0,00 \\
\hline 26 & Sim & 5,63 & 3,30 & 0,00 & 0,00 & 0,00 \\
\hline 27 & Sim & 2,88 & 2,62 & 0,00 & 0,00 & 0,00 \\
\hline 28 & Sim & 2,66 & 0,00 & 0,00 & 0,00 & 0,00 \\
\hline 29 & Sim & 7,81 & 6,71 & 0,00 & 0,00 & 0,00 \\
\hline 30 & Sim & 0,00 & 4,38 & 0,00 & 4,58 & 3,05 \\
\hline 31 & Sim & 0,00 & 2,60 & 1,32 & 0,00 & 0,00 \\
\hline 32 & Sim & 4,50 & 4,09 & 0,00 & 5,34 & 2,98 \\
\hline 33 & Sim & 5,52 & 6,72 & 0,00 & 0,00 & 3,81 \\
\hline 34 & Sim & 7,45 & 6,56 & 5,58 & 6,21 & 6,40 \\
\hline 35 & Sim & 6,01 & 6,59 & 2,68 & 0,00 & 2,30 \\
\hline 36 & Sim & 5,17 & 4,06 & 0,00 & 0,00 & 4,60 \\
\hline 37 & Sim & 7,35 & 5,65 & 4,39 & 4,77 & 4,31 \\
\hline 38 & Sim & 6,11 & 0,00 & 0,00 & 0,00 & 3,45 \\
\hline 39 & Sim & 4,14 & 3,64 & 0,00 & 1,32 & 0,00 \\
\hline 40 & Sim & 5,09 & 3,62 & 4,51 & 0,00 & 0,00 \\
\hline 41 & Sim & 7,48 & 6,98 & 7,13 & 6,17 & 6,07 \\
\hline 42 & Sim & 5,77 & 5,10 & 2,08 & 1,32 & 3,91 \\
\hline 43 & Sim & 6,74 & 5,24 & 2,08 & 0,00 & 2,30 \\
\hline 44 & Sim & 3,30 & 2,08 & 0,00 & 0,00 & 0,00 \\
\hline 45 & Sim & 6,78 & 6,86 & 3,62 & 2,15 & 6,47 \\
\hline
\end{tabular}

HS: Hipoclorito de Sódio; RC: Ricinus communis. 


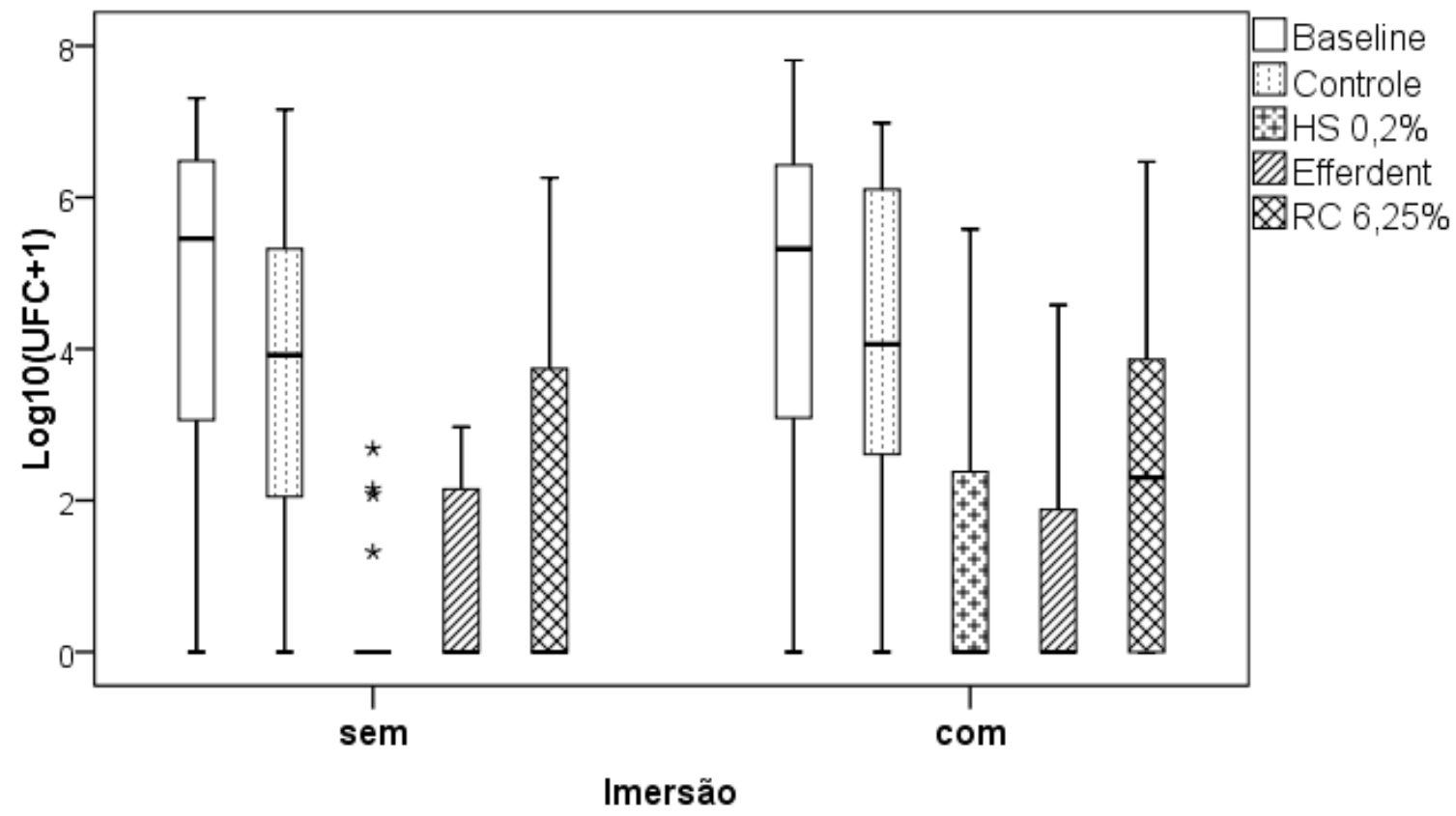

Figura 37: Box-plot de UFC/mL de $S$. mutans após transformação em log10(UFC+1).

A partir do teste de Friedman, observou-se diferença significante entre as soluções $(\mathrm{p}<0,001)$. A Tabela 7 apresenta os postos médios obtidos pelo teste, bem como os resultados das comparações múltiplas.

Tabela 7. Postos médios (PM) e resultados do teste de Friedman seguido por comparações múltiplas para os resultados da ação antimicrobiana da S. mutans.

\begin{tabular}{ccccc} 
Soluções & \multicolumn{2}{c}{ Sem imersão da escova } & \multicolumn{2}{c}{ Com imersão da escova } \\
\cline { 2 - 5 } & PM & Fr (P-Valor) & PM & Fr (P-Valor) \\
\hline Baseline & $4,52^{\mathrm{A}}$ & & $4,54^{\mathrm{A}}$ & \\
Solução salina (controle) & $3,68^{\mathrm{AB}}$ & & $3,67^{\mathrm{AB}}$ & \\
Hipoclorito de sódio 0,2\% & $1,96^{\mathrm{C}}$ & 53,95 & $2,13^{\mathrm{C}}$ & 46,32 \\
Efferdent & $2,18^{\mathrm{C}}$ & $(<0,001)^{*}$ & $2,26^{\mathrm{C}}$ & $(<0,001)^{*}$ \\
Ricinus communis 6,25\% & $2,75^{\mathrm{BC}}$ & & $2,39^{\mathrm{BC}}$ & \\
\hline
\end{tabular}

*Diferença significante $(\mathrm{P}<0,05)$. Comparação entre pares: letras distintas indicam diferença significante. 
Todas as soluções testadas apresentaram ação antimicrobiana frente $S$. mutans em ambos os grupos quando comparado ao Baseline $(\mathrm{p}<0,001)$. Para ambos os grupos, a solução controle apresentou valores intermediários ao baseline e Ricinus communis 6,25\%, que apresentou valores intermediários à solução controle, Efferdent e hipoclorito de sódio a 0,2\%.

\subsubsection{Escova}

Os dados originais da contagem total de UFC/mL de Candida spp. e $S$. mutans estão apresentados no Apêndice F (tabelas F1 e F2, respectivamente). A tabela 8 mostra as leituras do total de UFC/mL presentes nas escovas específicas de prótese total, após transformação em log $(\mathrm{UFC}+1)$, de Candida spp. após o uso de cada uma das soluções higienizadoras. A figura 38 mostra o box-plot de UFC/mL obtidos, transformados em log (UFC+1), para Candida spp..

Tabela 8. Total de UFC/mL, em $\log (\mathrm{UFC} / \mathrm{mL}+1)$, de Candida spp.

\begin{tabular}{cccccc}
\hline Pacientes & Imersão & Controle & HS 0,2\% & Efferdent & RC 6,25\% \\
\hline $\mathbf{1}$ & Não & 0,00 & 0,00 & 2,81 & 0,00 \\
$\mathbf{2}$ & Não & 0,00 & 2,30 & 0,00 & 2,08 \\
$\mathbf{3}$ & Não & 2,94 & 1,32 & 2,30 & 1,32 \\
$\mathbf{4}$ & Não & 3,02 & 0,00 & 0,00 & 1,32 \\
$\mathbf{5}$ & Não & 0,00 & 0,00 & 0,00 & 2,15 \\
$\mathbf{6}$ & Não & 0,00 & 0,00 & 2,30 & 0,00 \\
$\mathbf{7}$ & Não & 1,79 & 0,00 & 0,00 & 1,32 \\
$\mathbf{8}$ & Não & 0,00 & 0,00 & 0,00 & 1,79 \\
$\mathbf{9}$ & Não & 1,32 & 0,00 & 0,00 & 0,00 \\
$\mathbf{1 0}$ & Não & 0,00 & 2,83 & 0,00 & 0,00 \\
$\mathbf{1 1}$ & Não & 0,00 & 0,00 & 1,32 & 0,00 \\
$\mathbf{1 2}$ & Não & 4,33 & 1,61 & 0,00 & 1,32 \\
$\mathbf{1 3}$ & Não & 2,00 & 0,00 & 0,00 & 1,91 \\
$\mathbf{1 4}$ & Não & 4,28 & 0,00 & 2,00 & 4,51 \\
$\mathbf{1 5}$ & Não & 2,30 & 0,00 & 0,00 & 0,00 \\
\hline
\end{tabular}

HS: Hipoclorito de Sódio; RC: Ricinus communis. 
Tabela 8 (continuação). Total de UFC/mL, em $\log (\mathrm{UFC} / \mathrm{mL}+1)$, de Candida spp.

\begin{tabular}{|c|c|c|c|c|c|}
\hline Pacientes & Imersão & Controle & HS 0,2\% & Efferdent & RC 6,25\% \\
\hline 16 & Não & 4,21 & 1,32 & 2,00 & 3,47 \\
\hline 17 & Não & 2,87 & 2,26 & 2,38 & 2,00 \\
\hline 18 & Não & 0,00 & 0,00 & 0,00 & 0,00 \\
\hline 19 & Não & 0,00 & 1,91 & 1,91 & 2,62 \\
\hline 20 & Não & 0,00 & 0,00 & 2,00 & 0,00 \\
\hline 21 & Não & 0,00 & 1,79 & 1,32 & 5,19 \\
\hline 22 & Não & 3,27 & 1,61 & 2,38 & 2,45 \\
\hline 23 & Sim & 0,00 & 2,15 & 0,00 & 1,79 \\
\hline 24 & Sim & 0,00 & 0,00 & 0,00 & 0,00 \\
\hline 25 & Sim & 0,00 & 0,00 & 0,00 & 0,00 \\
\hline 26 & Sim & 0,00 & 1,32 & 0,00 & 0,00 \\
\hline 27 & Sim & 0,00 & 0,00 & 0,00 & 0,00 \\
\hline 28 & Sim & 0,00 & 0,00 & 0,00 & 1,61 \\
\hline 29 & Sim & 0,00 & 1,32 & 2,15 & 0,00 \\
\hline 30 & Sim & 3,62 & 0,00 & 3,68 & 4,67 \\
\hline 31 & Sim & 0,00 & 0,00 & 0,00 & 0,00 \\
\hline 32 & Sim & 0,00 & 0,00 & 0,00 & 0,00 \\
\hline 33 & Sim & 1,91 & 0,00 & 0,00 & 3,57 \\
\hline 34 & Sim & 3,07 & 2,89 & 1,61 & 6,02 \\
\hline 35 & Sim & 0,00 & 1,61 & 0,00 & 0,00 \\
\hline 36 & Sim & 0,00 & 1,32 & 0,00 & 0,00 \\
\hline 37 & Sim & 3,60 & 0,00 & 0,00 & 2,45 \\
\hline 38 & Sim & 0,00 & 2,15 & 0,00 & 0,00 \\
\hline 39 & Sim & 4,90 & 1,32 & 1,32 & 1,32 \\
\hline 40 & Sim & 4,20 & 0,00 & 0,00 & 0,00 \\
\hline 41 & Sim & 0,00 & 0,00 & 1,32 & 4,20 \\
\hline 42 & Sim & 4,48 & 0,00 & 0,00 & 0,00 \\
\hline 43 & Sim & 0,00 & 1,79 & 0,00 & 0,00 \\
\hline 44 & Sim & 2,81 & 0,00 & 0,00 & 2,48 \\
\hline 45 & Sim & 2,21 & 0,00 & 3,55 & 3,46 \\
\hline
\end{tabular}

HS: Hipoclorito de Sódio; RC: Ricinus communis. 


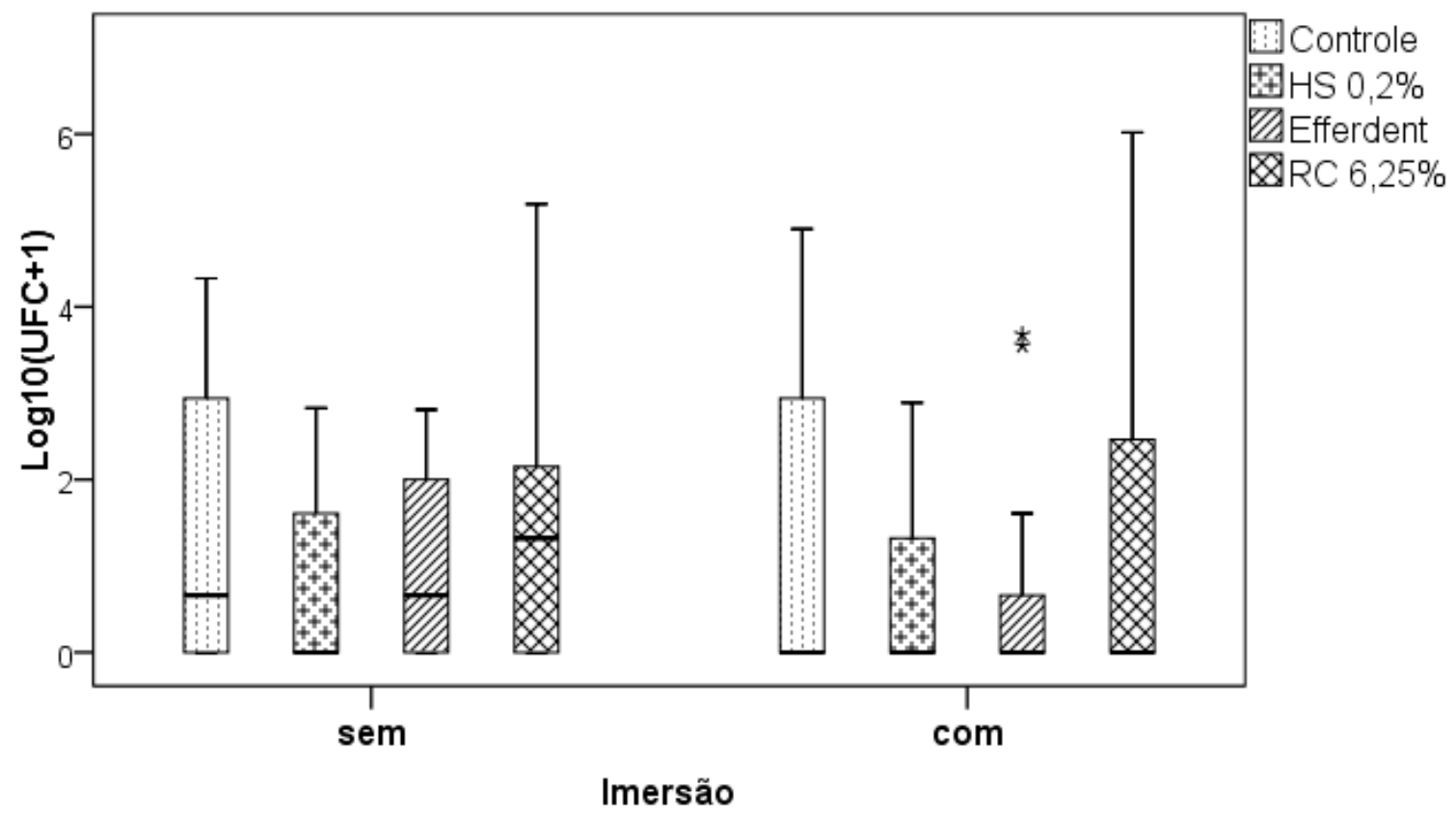

Figura 38: Box-plot de UFC/mL de Candida spp. após transformação em log10(UFC+1).

A partir do teste de Friedman, não se observou diferença significante entre as soluções. A Tabela 9 mostra os postos médios obtidos pelo teste, bem como os resultados das comparações múltiplas.

Tabela 9. Postos médios (PM) e resultados do teste de Friedman seguido por comparações múltiplas para os resultados da ação antimicrobiana da Candida spp.

\begin{tabular}{ccccc}
\multirow{2}{*}{ Soluções } & \multicolumn{2}{c}{ Sem imersão da escova } & \multicolumn{2}{c}{ Com imersão da escova } \\
\cline { 2 - 5 } & PM & Fr (P-Valor) & PM & Fr (P-Valor) \\
\hline Solução salina (controle) & $2,86^{\mathrm{A}}$ & & $2,57^{\mathrm{A}}$ & \\
Hipoclorito de sódio 0,2\% & $2,09^{\mathrm{A}}$ & 6,07 & $2,50^{\mathrm{A}}$ & 2,54 \\
Efferdent & $2,36^{\mathrm{A}}$ & $(=0,108)$ & $2,24^{\mathrm{A}}$ & $(=0,467)$ \\
Ricinus communis $\mathbf{6 , 2 5 \%}$ & $2,68^{\mathrm{A}}$ & & $2,70^{\mathrm{A}}$ & \\
\hline
\end{tabular}

Comparação entre pares: letras distintas indicam diferença significante.

Não houve diferença significante na contagem UFC/mL de Candida spp. presentes na escova entre as soluções avaliadas e o controle, tanto para o grupo que não realizou a imersão das escovas $(\mathrm{p}=0,108)$, como para os que realizaram o procedimento $(\mathrm{p}=0,467)$. 
A tabela 10 mostra as leituras do total de UFC/mL presentes nas próteses superiores, após transformação em log $(\mathrm{UFC}+1)$, de $S$. mutans, após o uso de cada uma das soluções higienizadoras. A figura 39 mostra o box-plot de UFC/mL obtidos, transformados em og (UFC+1), para S. mutans.

Tabela 10. Total de UFC/mL, em $\log (\mathrm{UFC} / \mathrm{mL}+1)$, de $S$. mutans.

\begin{tabular}{|c|c|c|c|c|c|}
\hline Pacientes & Imersão & Controle & HS $0,2 \%$ & Efferdent & RC 6,25\% \\
\hline 1 & Não & 0,00 & 0,00 & 0,00 & 0,00 \\
\hline 2 & Não & 1,91 & 0,00 & 0,00 & 0,00 \\
\hline 3 & Não & 0,00 & 0,00 & 0,00 & 0,00 \\
\hline 4 & Não & 0,00 & 0,00 & 0,00 & 0,00 \\
\hline 5 & Não & 0,00 & 0,00 & 0,00 & 0,00 \\
\hline 6 & Não & 2,64 & 0,00 & 0,00 & 1,79 \\
\hline 7 & Não & 3,42 & 0,00 & 0,00 & 0,00 \\
\hline 8 & Não & 0,00 & 0,00 & 0,00 & 3,06 \\
\hline 9 & Não & 1,32 & 0,00 & 0,00 & 0,00 \\
\hline 10 & Não & 2,00 & 3,19 & 0,00 & 0,00 \\
\hline 11 & Não & 3,15 & 1,32 & 2,21 & 0,00 \\
\hline 12 & Não & 3,81 & 0,00 & 0,00 & 2,82 \\
\hline 13 & Não & 0,00 & 0,00 & 1,91 & 1,79 \\
\hline 14 & Não & 0,00 & 2,00 & 2,60 & 0,00 \\
\hline 15 & Não & 2,45 & 2,92 & 0,00 & 0,00 \\
\hline 16 & Não & 4,69 & 0,00 & 0,00 & 0,00 \\
\hline 17 & Não & 0,00 & 0,00 & 3,13 & 0,00 \\
\hline 18 & Não & 0,00 & 0,00 & 0,00 & 0,00 \\
\hline 19 & Não & 0,00 & 0,00 & 0,00 & 1,91 \\
\hline 20 & Não & 0,00 & 0,00 & 4,99 & 4,22 \\
\hline 21 & Não & 0,00 & 1,32 & 0,00 & 6,06 \\
\hline 22 & Não & 3,20 & 0,00 & 0,00 & 0,00 \\
\hline 23 & Sim & 1,91 & 0,00 & 1,32 & 1,61 \\
\hline 24 & Sim & 1,61 & 0,00 & 0,00 & 0,00 \\
\hline 25 & Sim & 2,92 & 0,00 & 0,00 & 0,00 \\
\hline 26 & Sim & 2,08 & 0,00 & 0,00 & 0,00 \\
\hline 27 & Sim & 1,61 & 0,00 & 0,00 & 0,00 \\
\hline 28 & Sim & 0,00 & 0,00 & 0,00 & 0,00 \\
\hline 29 & Sim & 5,05 & 0,00 & 0,00 & 0,00 \\
\hline 30 & Sim & 3,16 & 0,00 & 4,25 & 4,05 \\
\hline
\end{tabular}

HS: Hipoclorito de Sódio; RC: Ricinus communis. 
Tabela 10 (continuação). Total de UFC/mL, em $\log (\mathrm{UFC} / \mathrm{mL}+1)$, de $S$. mutans.

\begin{tabular}{cccccc}
\hline Pacientes & Imersão & Controle & HS 0,2\% & Efferdent & RC 6,25\% \\
\hline $\mathbf{3 1}$ & Sim & 2,08 & 1,32 & 0,00 & 0,00 \\
$\mathbf{3 2}$ & Sim & 4,09 & 0,00 & 3,07 & 5,77 \\
$\mathbf{3 3}$ & Sim & 4,61 & 0,00 & 0,00 & 1,91 \\
$\mathbf{3 4}$ & Sim & 2,08 & 0,00 & 2,00 & 6,40 \\
$\mathbf{3 5}$ & Sim & 2,51 & 2,68 & 0,00 & 0,00 \\
$\mathbf{3 6}$ & Sim & 2,53 & 0,00 & 0,00 & 2,00 \\
$\mathbf{3 7}$ & Sim & 2,30 & 4,99 & 0,00 & 5,37 \\
$\mathbf{3 8}$ & Sim & 0,00 & 0,00 & 0,00 & 0,00 \\
$\mathbf{3 9}$ & Sim & 4,17 & 0,00 & 0,00 & 0,00 \\
$\mathbf{4 0}$ & Sim & 0,00 & 2,97 & 0,00 & 0,00 \\
$\mathbf{4 1}$ & Sim & 1,61 & 3,13 & 4,39 & 2,21 \\
$\mathbf{4 2}$ & Sim & 2,21 & 0,00 & 0,00 & 0,00 \\
$\mathbf{4 3}$ & Sim & 3,37 & 0,00 & 1,61 & 2,21 \\
$\mathbf{4 4}$ & Sim & 1,91 & 0,00 & 0,00 & 0,00 \\
$\mathbf{4 5}$ & Sim & 2,82 & 0,00 & 3,03 & 5,24 \\
\hline
\end{tabular}

HS: Hipoclorito de Sódio; RC: Ricinus communis.

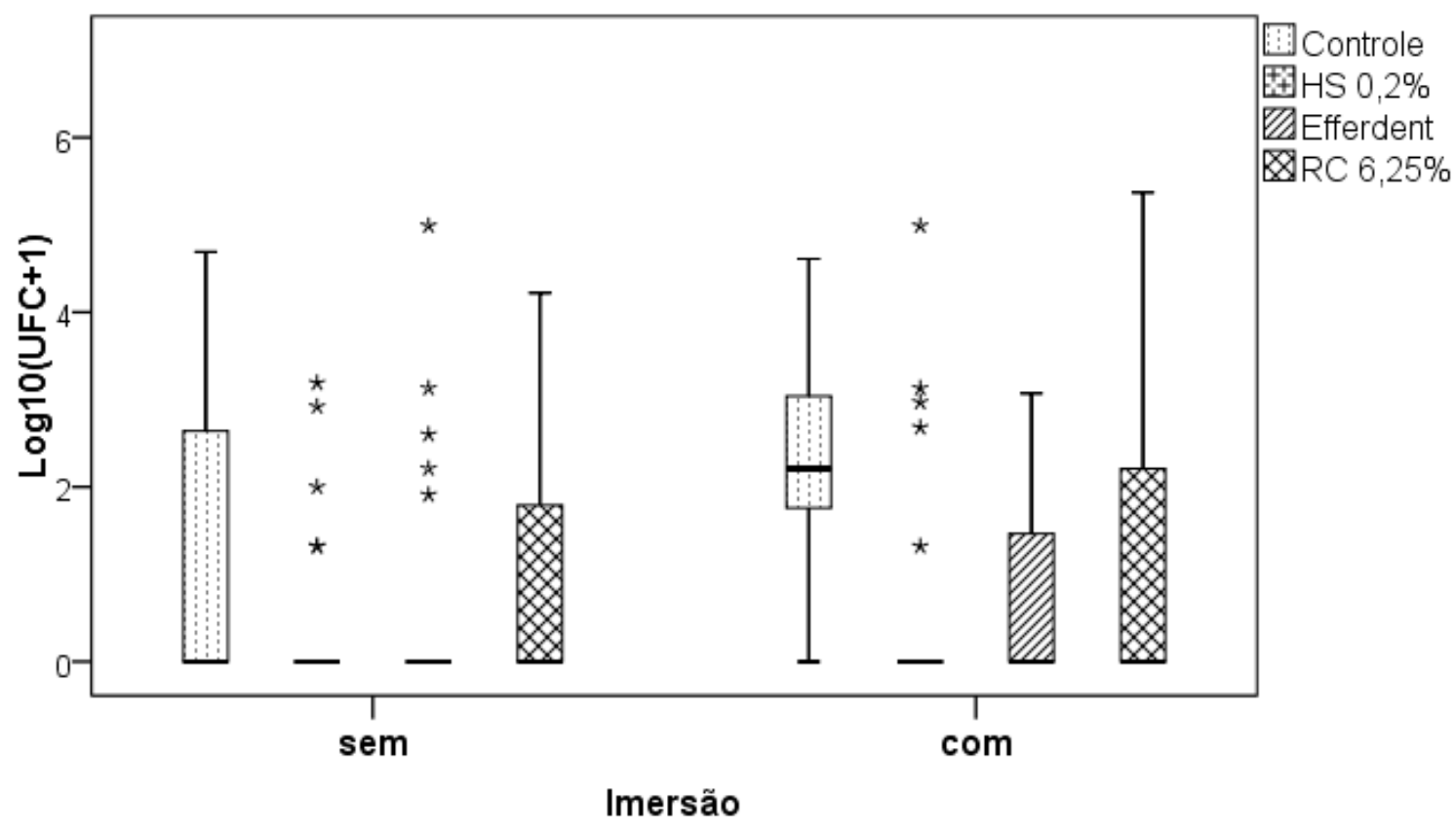

Figura 39: Box-plot de UFC/mL de $S$. mutans após transformação em log10(UFC+1). 
A partir do teste de Friedman, para o grupo sem imersão, não se observou diferença significante entre as soluções $(\mathrm{p}=0,288)$, mas houve diferença para o grupo com imersão da escova $(\mathrm{p}<0,001)$. A Tabela 11 apresenta os postos médios obtidos pelo teste, bem como os resultados das comparações múltiplas.

Tabela 11. Postos médios (PM) e resultados do teste de Friedman seguido por comparações múltiplas para os resultados da ação antimicrobiana da S. mutans.

\begin{tabular}{ccccc}
\hline & \multicolumn{2}{c}{ Sem imersão da escova } & \multicolumn{2}{c}{ Com imersão da escova } \\
\cline { 2 - 5 } Soluções & PM & Fr (P-Valor) & PM & Fr (P-Valor) \\
\hline Solução salina (controle) & $2,84^{\mathrm{A}}$ & & $3,26^{\mathrm{A}}$ & \\
Hipoclorito de sódio 0,2\% & $2,30^{\mathrm{A}}$ & 3,76 & $2,04^{\mathrm{B}}$ & 17,33 \\
Efferdent & $2,41^{\mathrm{A}}$ & $(\mathrm{p}=0,288)$ & $2,13^{\mathrm{B}}$ & $(\mathrm{p}<0,001)$ \\
Ricinus communis $\mathbf{6 , 2 5 \%}$ & $2,45^{\mathrm{A}}$ & & $2,59^{\mathrm{AB}}$ & \\
\hline
\end{tabular}

*Diferença significante $(\mathrm{P}<0,05)$. Comparação entre pares: letras distintas indicam diferença significante.

Para o grupo sem imersão, não houve diferença significante entre as soluções $(\mathrm{p}<0,001)$. Para o grupo com imersão da escova o Efferdent e hipoclorito de sódio a 0,2\% mostraram redução na contagem $\mathrm{UFC} / \mathrm{mL}$ de $S$. mutans presentes na escova quando comparado ao grupo Controle ( $\mathrm{p}=0,001)$. A solução de Ricinus communis a 6,25\% apresentou valores intermediários.

\subsubsection{Médias de $\log (\mathrm{UFC} / \mathrm{mL})$}

Tabela 12. Média e diferença de $\log (\mathrm{UFC} / \mathrm{mL})$ de Candida spp. para cada solução comparado ao baseline.

\begin{tabular}{lccccc}
\hline MÉDIA UFC/mL de Candida spp. & Baseline & Controle & HS 0,2\% & Efferdent & RC 6,25\% \\
\hline Sem imersão da escova & 3,65 & 2,44 & 0,71 & 1,49 & 2,29 \\
Log (Baseline - solução) & & 1,21 & 2,94 & 2,16 & 1,36 \\
Com imersão da escova & 3,87 & 2,67 & 1,11 & 1,17 & 1,60 \\
Log (Baseline - solução) & & 1,20 & 2,76 & 2,70 & 2,27 \\
\hline
\end{tabular}

Tabela 13. Média e diferença de $\log (\mathrm{UFC} / \mathrm{mL})$ de $S$. mutans para cada solução comparado ao baseline.

\begin{tabular}{lccccc}
\hline MÉDIA UFC/mL de S. mutans & Baseline & Controle & HS 0,2\% & Efferdent & RC 6,25\% \\
\hline Sem imersão da escova & 4,65 & 3,51 & 0,37 & 0,88 & 1,82 \\
Log (Baseline - solução) & & 1,14 & 4,28 & 3,77 & 2,83 \\
Com imersão da escova & 4,78 & 3,91 & 1,45 & 1,51 & 2,22 \\
Log (Baseline - solução) & & 0,87 & 3,33 & 3,27 & 2,56 \\
\hline
\end{tabular}

Quando comparadas ao baseline, a solução de hipoclorito de sódio a 0,2\% apresentou valores menores de $\log (\mathrm{UFC} / \mathrm{mL})$ de Candida spp.e $S$. mutans presentes nas próteses dos dois grupos (com e sem imersão da escova), enquanto a Ricinus communis a 6,25\% apresentou os maiores valores. 


\subsubsection{Microscopia Eletrônica de Varredura (MEV)}

As figuras de 40 a 43 apresentam imagens da microscopia eletrônica de varredura da superfície das cerdas das escovas específicas de próteses totais, após serem expostas aos protocolos de higiene de 7 dias.

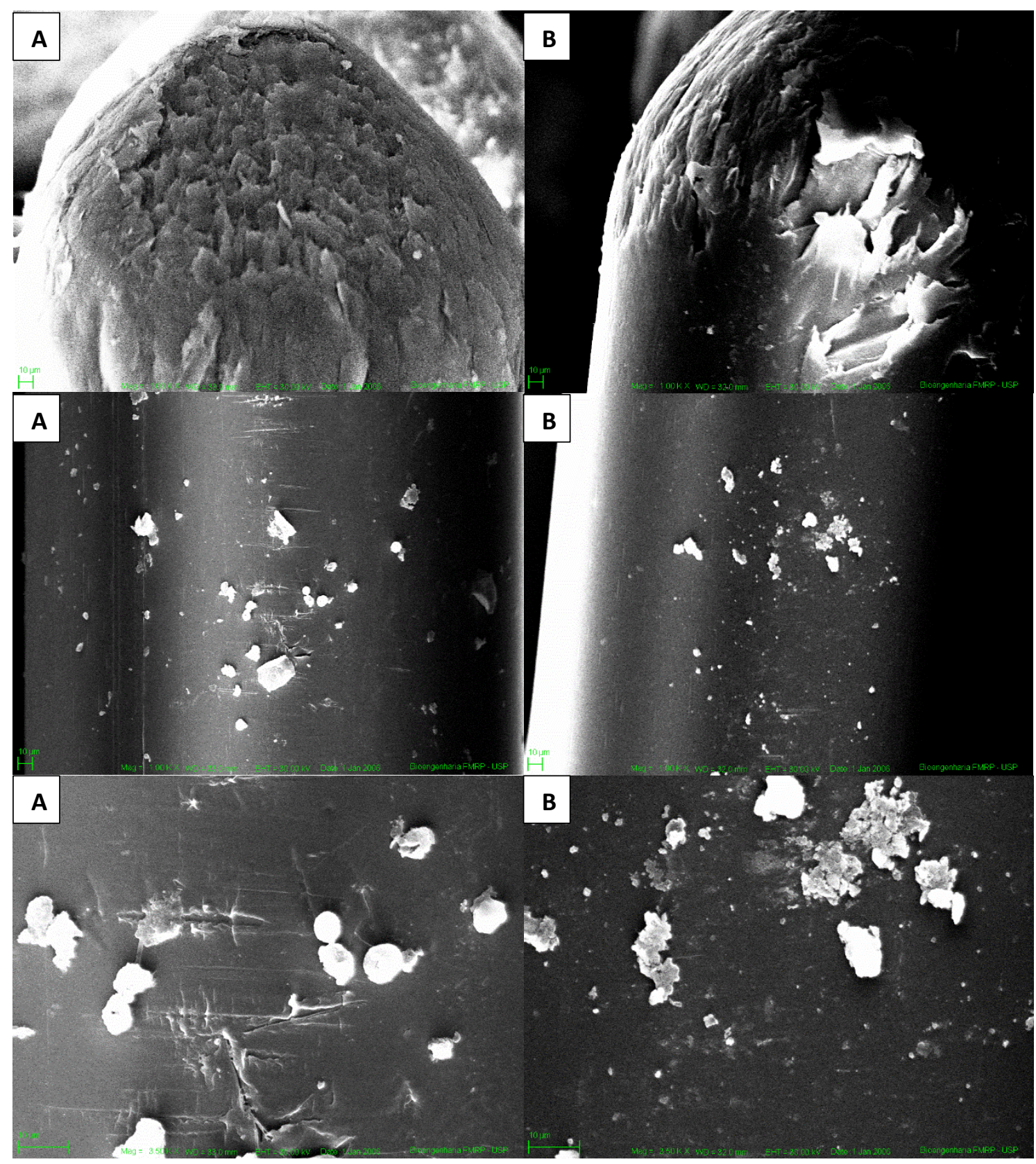

Figura 40. Fotomicrográficas da superfície das cerdas após 7 dias de protocolo de imersão na solução controle, sem imersão (A) ou com imersão (B) das escovas, em aumentos de 1000x e 3500x. 


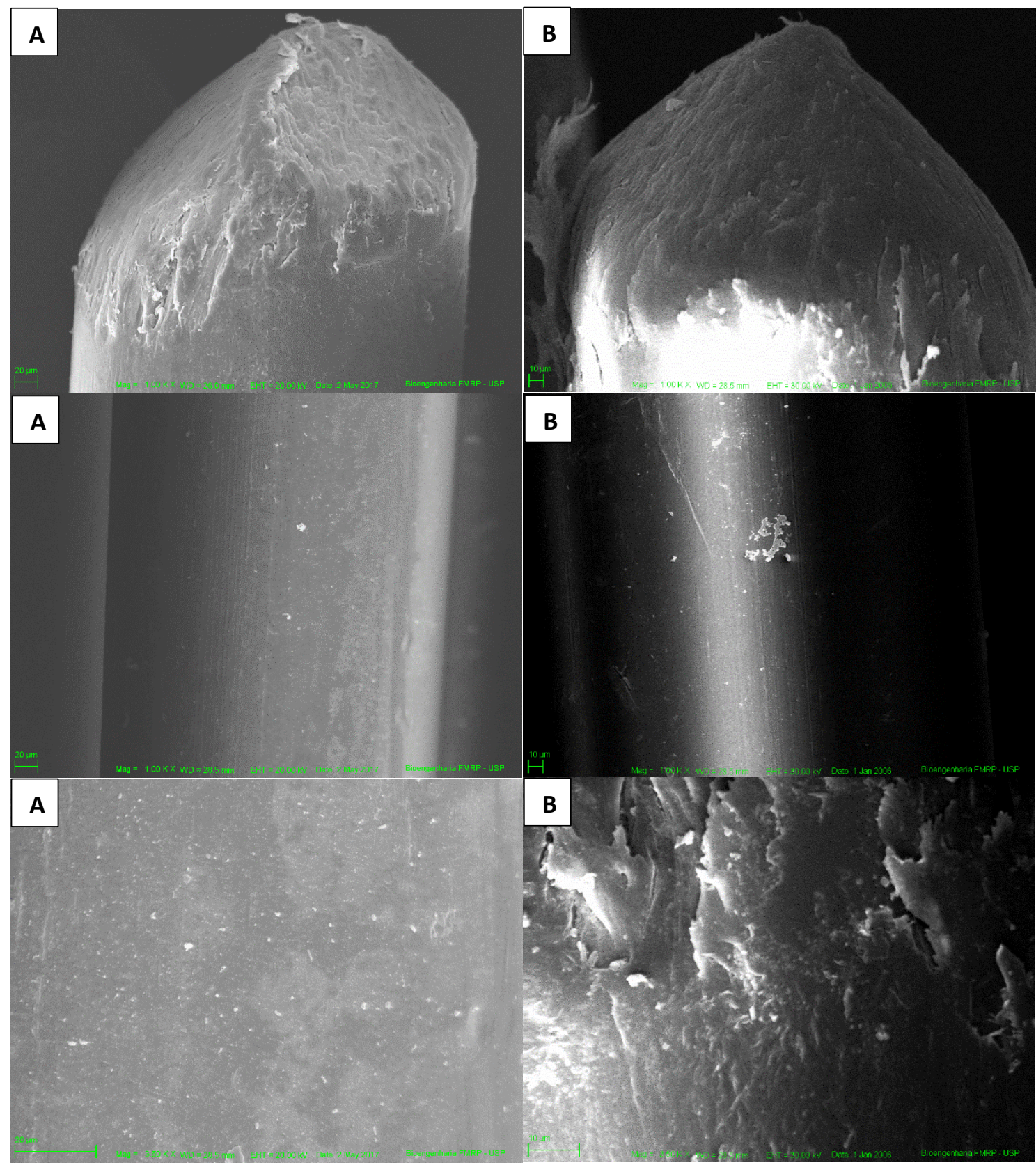

Figura 41. Fotomicrográficas da superfície das cerdas após 7 dias de protocolo de imersão na solução de hipoclorito de sódio a $0,2 \%$, sem imersão (A) ou com imersão (B) das escovas, em aumentos de 1000x e 3500x. 


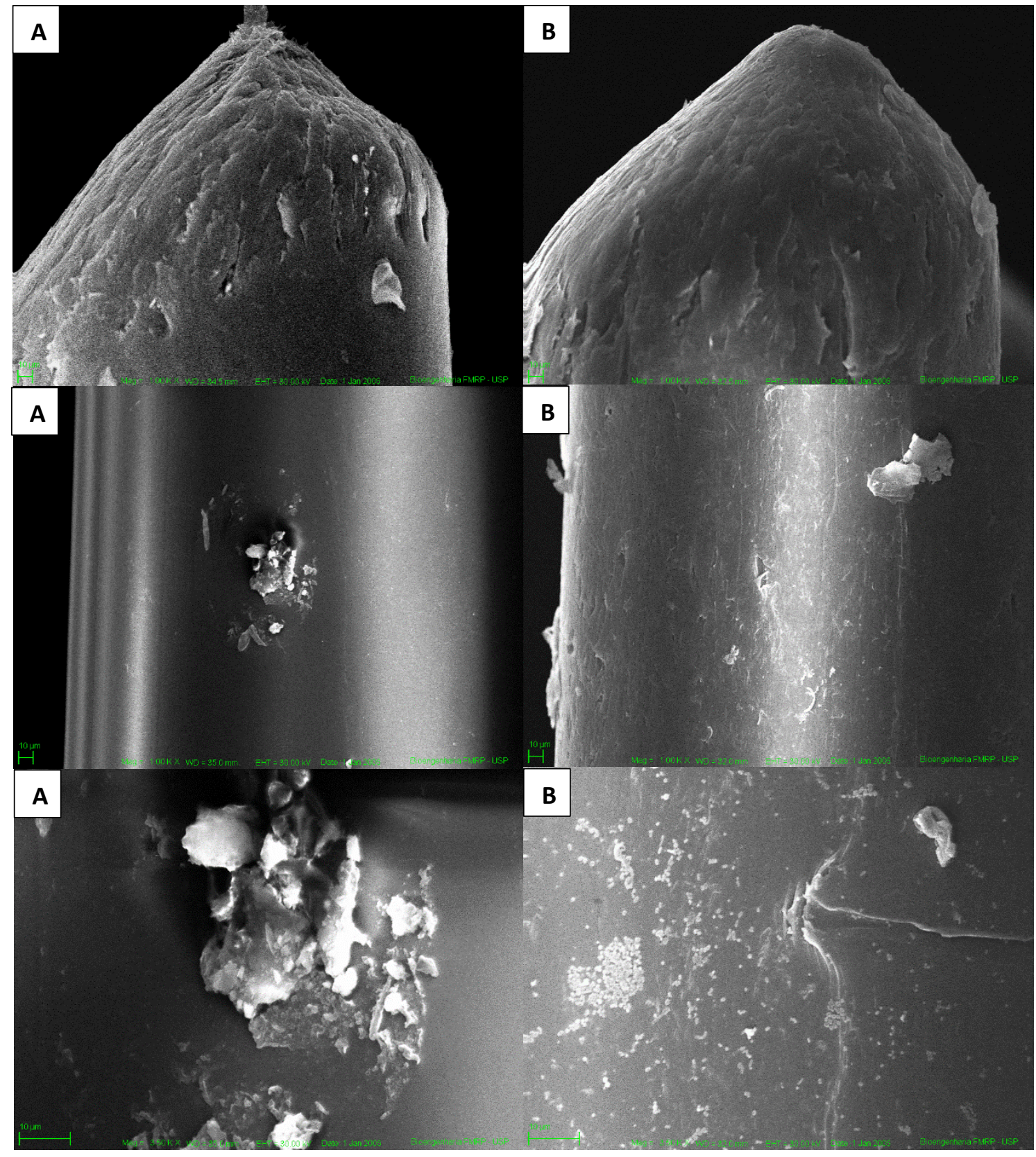

Figura 42. Fotomicrográficas da superfície das cerdas após 7 dias de protocolo de imersão na solução Efferdent, sem imersão (A) ou com imersão (B) das escovas, em aumentos de 1000x e 3500x. 


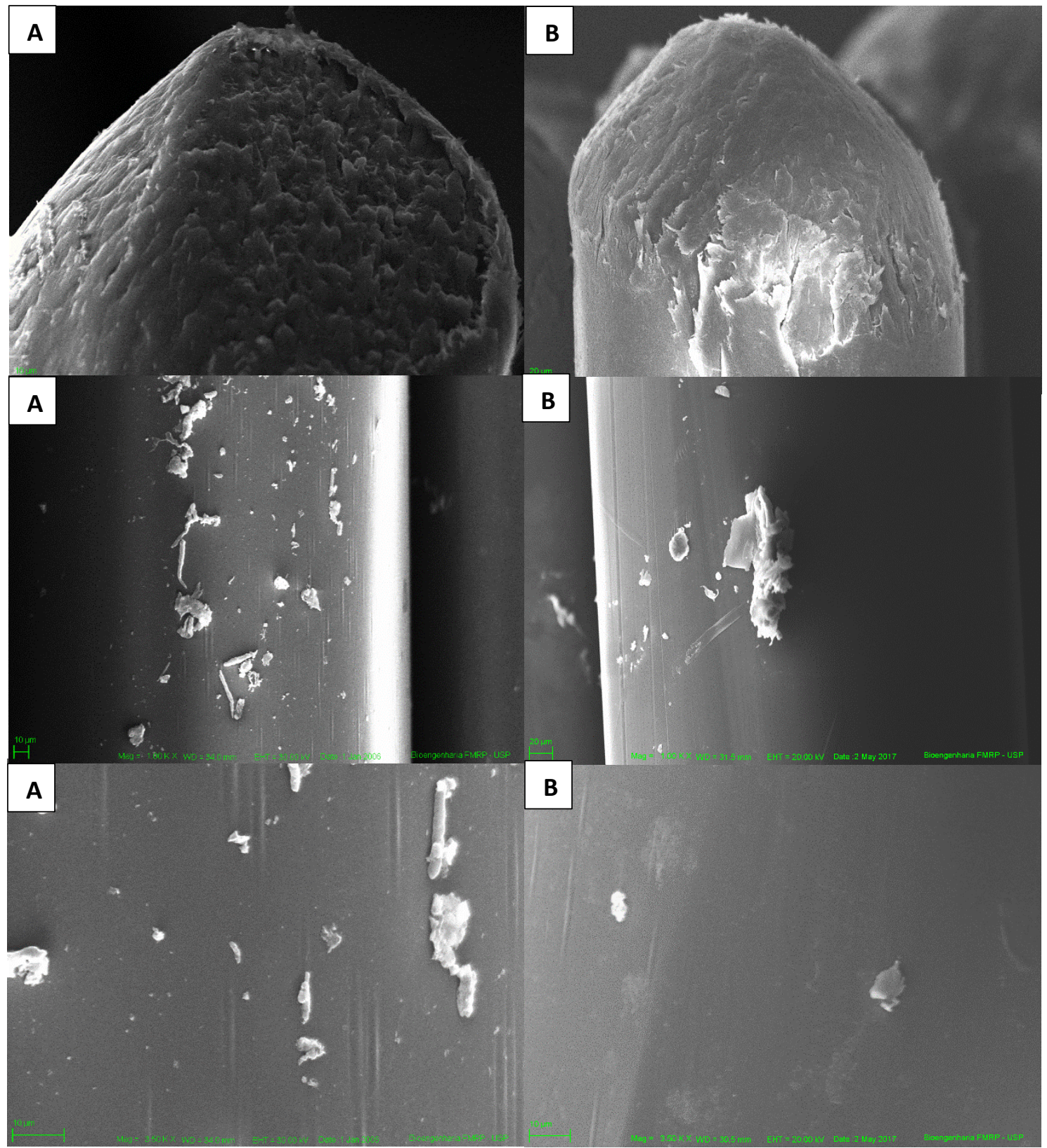

Figura 43. Fotomicrográficas da superfície das cerdas após 7 dias de protocolo de imersão na solução de Ricinus communis a 6,25\%, sem imersão (A) ou com imersão (B) das escovas, em aumentos de 1000x e 3500x.

As imagens em microscopia eletrônica foram avaliadas de forma qualitativa e mostraram grande deterioração das cerdas após o protocolo de higienização empregado. A solução de hipoclorito de sódio promoveu maiores danos às cerdas do grupo com imersão, quando comparadas soluções Efferdent® e Ricinus communis a 6,25\%. Para o grupo sem imersão das escovas, não foi possível notar visualmente diferenças entre as soluções avaliadas. 



\section{Discussão}



Vários estudos relacionam a precariedade da higiene oral ao acúmulo de biofilme (Barbeau et al., 2003; Webb Thomas e Whittle, 2005; Badaró et al., 2017), de forma que tornase extremamente importante avaliar a capacidade de materiais e métodos quanto à eliminação do biofilme, para que os tecidos orais sejam preservados e patologias orais e sistêmicas sejam prevenidas (Nikawa; Hamada; Yamamoto, 1998; Li et al., 2000; Scannapieco, 2007; Przybyłowska et al., 2014).

Este estudo avaliou o efeito de soluções higienizadoras de imersões para próteses totais à base de hipocloritos alcalinos, peróxidos alcalinos e Ricinus communis, quanto à eficácia do controle do biofilme, por meio de análise clínica. Por considerar importante a associação de um higienizador químico à escovação, para auxiliar na obtenção de ação antimicrobiana efetiva e também limpeza adequada da prótese (Nikawa et al., 1999; Shay, 2000; Paranhos et al., 2007a,b; Paranhos et al., 2009; Souza et al., 2009; Felton et al., 2011), os pacientes foram instruídos a empregar o método associado de higiene. A escovação foi realizada com escovas específicas para próteses totais, devido à efetividade frente à remoção do biofilme (Silva; Paranhos, 2006; Fernandes et al., 2007) e, como agente auxiliar, o sabonete líquido neutro, por não conter agentes antimicrobianos e abrasivos (Salles et al., 2007; Paranhos et al., 2013). O período de imersão empregado foi de 20 minutos, pelo fato de ser usualmente recomendado para a higiene de próteses totais (Jagger; Harrison, 1995; Felton et al., 2011) e também, com o objetivo de analisar a efetividade das soluções em tempo reduzido de imersão, requisito importante de um higienizador de próteses totais (Felton et al., 2011).

Para minimizar a ocorrência de vieses, todos os participantes foram orientados a empregar os métodos de higiene (escovação e imersão) de forma padronizada, sendo as soluções empregadas em configuração cruzada do tipo Quadrado Latino (Latin square) e em sequência aleatória (randomizada). A semana de wash out foi instituída visando evitar a ocorrência de possível efeito residual de um produto para o outro (efeito carry-over).

Um dos higienizadores selecionados foi o hipoclorito de sódio, devido à ação bactericida e fungicida (Yilmaz et al., 2005; Buergers et al., 2008). Estudos foram conduzidos em concentrações de $0,25 \% ; 0,5 \% ; 1 \% ; 2 \% ; 5,25 \%$, sendo, em grande parte, constituídos de metodologias in vitro (Nikawa et al., 1999, Souza et al., 2009; Felton et al., 2011). Diversos estudos, relacionados à higienização de próteses totais, têm sido conduzidos, porém em concentrações mais altas e em diferentes períodos de imersão e/ou uso. No entanto, Arruda et al. (2017) mostraram a possibilidade do uso de uma solução diluída a 0,20\%, por serem seguras 
e, dessa forma, podem ser utilizadas como higienizadores de próteses totais por apresentarem ação antimicrobiana, efetividade na remoção do biofilme e não causarem efeitos deletérios aos materiais constituintes do aparelho protético (Arruda et al., 2018). Com isso, a concentração de $0,20 \%$ foi selecionada por sua efetividade, sendo considerado um controle positivo no presente estudo.

Os peróxidos alcalinos constituem-se em método popular de higiene, e podem ser indicados para imersões, de acordo com o fabricante, de 3 minutos a 8 horas. Estudos mostram que a associação entre os peróxidos alcalinos com a escovação, consiste em um efetivo método de higiene (Paranhos et al., 2007a, 2009; Silva-Lovato et al., 2010; Andrade et al., 2011, 2014; Cruz et al., 2011); porém, fatores como a constituição do agente higienizador empregado, o tempo de uso dessas soluções, a temperatura da água, o tempo de imersão e o seguimento das instruções do fabricante são considerados críticos para a prevenção de ocorrência de efeitos adversos aos materiais constituintes do aparelho protético (Mcneme; Von Gonten; Woolsey, 1991; Ünlü; Altay; Sahmali, 1996; Ma; Johnson; Gordon, 1997; Polyzois et al., 1997; Sato et al., 2005; Hong et al., 2009; Felipucci et al., 2011a,b; Paranhos et al., 2013; Moon; Powers; Kiat-Amnuay, 2014; Arruda et al., 2015; Haghi et al., 2015).

A solução de Ricinus communis, classificada como droga bruta ou crua (Nikawa et al., 1999), foi também selecionada pela baixa toxidade, biocompatibilidade e propriedades detergentes e antimicrobianas (Meneghin et al., 2006). Em relação às próteses totais, estudos prévios avaliaram soluções e dentifrícios à base de Ricinus communis (Pisani et al., 2010; Malheiros-Segundo, 2011; Andrade et al., 2012; Leite, 2012; Pisani et al., 2012a,b; Pinelli et al., 2013; Andrade et al., 2014; Salles et al., 2015a,b; Badaró et al., 2016,2017; Arruda et al., 2017); porém, ainda não existe um consenso quanto a melhor concentração a ser utilizada, visando maior eficiência na remoção do biofilme e ação antimicrobiana, com ausência de efeitos adversos aos materiais constituintes da prótese. A partir de estudo piloto feito por Badaró (2017), a concentração inibitória mínima, efetiva para C. albicans e $C$. glabrata, da solução de Ricinus communis foi de $6,25 \%$, sendo, dessa forma, a concentração selecionada para avaliação neste estudo.

Para a avaliação da propriedade de remoção de biofilme, o protocolo de quantificação de biofilme estabelecido seguiu estudos prévios (Paranhos et al., 2007a,b; Cruz et al., 2011; Andrade et al., 2012, 2014; Peracini et al., 2016; Badaró et al., 2017; Arruda et al., 2017), de forma que fatores essenciais foram definidos, como uso do evidenciador Vermelho neutro a $1 \%$ 
(Silva-Lovato et al., 2002; Silva; Paranhos, 2006; Paranhos et al., 2007b), fotografia para mensuração do biofilme (Sheen; Harrison, 2000) e emprego de método quantitativo computadorizado (Paranhos; Silva, 2004; Silva-Lovato et al., 2009).

O baixo número de perdas ocorridas durante o estudo pode ser considerado um indicativo da motivação dos participantes em relação ao comparecimento aos retornos e participação da pesquisa. As razões para as perdas não estavam associadas a fatores intrínsecos da pesquisa, como não aceitação dos produtos ou da técnica de higiene instruída, ou mesmo presença de efeitos deletérios dos produtos ao aparelho protético ou paciente. É importante salientar que, ao longo da pesquisa, não houve queixas por parte dos pacientes a respeito dos produtos empregados.

Para ambos os grupos (com e sem imersão da escova), os resultados mostraram redução dos níveis de biofilme do baseline e solução controle para as demais soluções, ou seja, após o uso do protocolo de higiene proposto. Esta redução, provavelmente, está relacionada ao efeito da ação mecânica proveniente do método de escovação (Paranhos et al., 2007a,b; Panzeri et al., 2009; Andrade et al., 2012). Os resultados também mostraram que as três soluções experimentais, foram eficazes frente à propriedade de remoção de biofilme. Isso ocorreu em ambos os grupos (com e sem imersão da escova).

Andrade et al. (2014), em estudo clínico randomizado, encontraram maior efetividade da solução de hipoclorito de sódio a 1\%, empregada em imersões de 20 minutos, enquanto as soluções de peróxido alcalino (Polident ${ }^{\circledR}$ ) e Ricinus communis a 2\% apresentaram efetividade intermediárias e semelhantes entre si. Essa diferença de resultados, pode estar relacionada a maior concentração do hipoclorito de sódio empregada. O hipoclorito de sódio a 0,5\% também foi avaliado por meio de estudos clínicos controlados, e mostrou-se efetivo frente à propriedade de remoção de biofilme em imersões de oito horas (Peracini et al., 2016) ou 10 a 20 minutos (Lima et al., 2006; Rossato et al., 2011; Badaró et al., 2017). Porém a ação antimicrobiana não foi avaliada. Além disso, diferentes metodologias foram utilizadas como quantificação de proteínas, metodologia in situ, através da confecção de aparelhos protéticos com espécimes e o uso de diferentes períodos de imersão, como 10 ou 20 minutos.

Estudos clínicos recentes verificaram a eficácia de concentrações diluídas de hipoclorito de sódio no controle do biofilme. Badaró et al. (2017) avaliaram uma solução de 0,25\%, e observaram redução da porcentagem de biofilme, em relação ao baseline e soluções de Ricinus communis a $10 \%$ e controle. Além disso, a concentração de $0,2 \%$ também se mostrou 
clinicamente efetiva na propriedade de remoção de biofilme de pacientes com estomatite protética (Arruda et al., 2017). Nossos resultados, foram semelhantes a estes estudos, e mostraram efetividade do hipoclorito de sódio a $0,2 \%$, porém na remoção do biofilme de pacientes sem estomatite protética. $\mathrm{O}$ fato de ser uma baixa concentração a torna mais segura, uma vez que além de ter efetividade frente ao controle do biofilme, não causa efeitos deletérios aos materiais constituintes das próteses (Arruda et al., 2018), o que possibilita maior longevidade da reabilitação da saúde bucal do paciente.

O presente estudo mostrou efetividade do Efferdent Power Clean Crystals® para a remoção do biofilme; no entanto, a literatura mostra uma grande variedade de resultados para essas soluções. Kulak et al. (1997) encontraram, por meio de microscopia eletrônica de varredura, maior efetividade do hipoclorito de sódio a 5\% em relação aos peróxidos Corega Tabs ${ }^{\circledR}$, Dentipur ${ }^{\circledR}$ e Fittydent ${ }^{\circledR}$, em imersões de 8 horas; esses diferentes resultados estão relacionados principalmente pela maior concentração e tempo de imersão empregados; além disso pelas diferentes metodologias de quantificação do biofilme empregadas. Rossato et al. (2011) avaliaram seis higienizadores frente à remoção do biofilme e concluíram que Corega Tabs® quando utilizado por 30 minutos apresentou melhor ação do que quando utilizada por 5 minutos e com efetividade mais próxima ao hipoclorito de sódio (Q'boa ${ }^{\circledR}$ a $0,45 \% /$ imersão de 10 minutos); no entanto, foi utilizada metodologia in situ, realizada em estudantes entre 20 e 25 anos, com bom estado de saúde. Quando avaliada em pacientes desdentados totais, Peracini et al. (2016) encontraram ineficácia do peróxido alcalino Corega Tabs®, o qual foi semelhante à solução controle, quando utilizado em imersões de 8 horas e comparado com o hipoclorito de sódio a $0,5 \%$, que apresentou maior efetividade.

A diversidade de resultados em relação aos peróxidos alcalinos, além de estar relacionado com a aplicação de diferentes metodologias, é também atribuída à diferença na composição presente nas formulações dessas soluções, o que interfere não apenas na eficácia, mas também nas alterações que podem acarretar na resina acrílica (Felipucci et al., 2011a,b; Davi et al., 2012; Coimbra et al., 2016; Peracini et al. 2016, 2017). Além disso, estudos clínicos que avaliam a remoção do biofilme dessas soluções são escassos. Desta forma, a efetividade na remoção do biofilme de próteses totais encontrada é relevante uma vez que avaliou essa propriedade por meio de estudo clínico randomizado.

O estudo também mostrou efetividade da solução de Ricinus communis a 6,25\% quanto à remoção do biofilme, resultados que diferem de estudos anteriores, nos quais a efetividade da 
solução de Ricinus communis em outras concentrações, foram intermediárias ou inexistentes (Peracini et al., 2016; Arruda et al., 2017; Badaró et al., 2017). Badaró et al. (2017), empregando 20 minutos imersão, constataram que uma solução a $10 \%$ foi superior à solução salina, porém apresentou ação inferior ao hipoclorito de sódio (0,25\% e 0,50\%). Arruda et al. (2017), mostraram que uma solução a $8 \%$ foi semelhante à solução controle, quanto à capacidade de remoção do biofilme, com imersões de 20 minutos, por 14 dias. No entanto, na concentração de $2 \%$ essa solução mostrou-se, também quando empregada em imersões de 20 minutos, semelhante ao peróxido alcalino Polident ${ }^{\circledR}$ (Andrade et al., 2014), o que pode indicar que concentrações mais altas podem ser menos efetivas, uma vez que essa menor concentração foi efetiva. Segundo et al. (2014), comparando o método mecânico (escovação), químico (imersão por 20 minutos em Ricinus communis a 2\%) e associado (mecânico com químico), encontraram maior efetividade do método mecânico isolado, porém o estudo foi conduzido em próteses reembasadas. O presente estudo mostrou efetividade da concentração de $6,25 \%$, sendo semelhante às soluções de hipoclorito de sódio a $0,2 \%$ e Efferdent ${ }^{\circledR}$, sendo um resultado importante, uma vez que o uso da Ricinus communis pode ser considerado no protocolo de higienização de próteses, principalmente para os pacientes que não têm a indicação do uso do hipoclorito de sódio, em casos de alergia, ou até incompatibilidade com o odor do hipoclorito de sódio.

O biofilme das próteses totais pode funcionar como um reservatório para infecções (Imsand et al., 2002; Ramage et al., 2004), uma vez que é constituído por mais de 30 espécies diferentes entre bactérias e fungos (Nikawa et al., 1999). A composição da microbiota do biofilme de próteses totais e de origem dentária são semelhantes e diferenciam-se pelo aumento da quantidade de Candida spp., fator importante no desenvolvimento de estomatite protética (Nikawa; Hamada; Yamamoto, 1998). Os micro-organismos da cavidade oral estão envolvidos não apenas no surgimento de patologias bucais como a estomatite protética (Akpan; Morgan, 2002; Barbeau et al., 2003; Ramage et al., 2004; Grimoud et al., 2005; Webb; Thomas; Whittle, 2005; Coco et al., 2008), mas também no aparecimento de diversas patologias sistêmicas, como endocardites, pneumonias, doenças pulmonares obstrutivas crônicas, infecções generalizadas do sistema respiratório e outras desordens sistêmicas (Nikawa; Hamada; Yamamoto, 1998; Senpuku et al., 2003; Coulthwaite; Verran, 2007).

Nossos resultados mostraram ação antimicrobiana frente Candida spp. de todas as soluções avaliadas em ambos os grupos (com e sem imersão da escova), sendo que, para o 
grupo de pacientes que não fizeram a imersão da escova, a solução controle apresentou valores intermediários, enquanto que para os que realizaram tal procedimento, não houve diferença significante entre baseline e controle $(\mathrm{p}=0,153)$. Para $S$. mutans, as soluções foram efetivas quando comparadas ao baseline ( $\mathrm{p}<0,001$ ). A solução de Ricinus communis a 6,25\% apresentou ação antimicrobiana intermediária em relação às soluções controle, Efferdent ${ }^{\circledR}$ e hipoclorito de sódio a 0,2\%. Em relação à ação das soluções nas escovas específicas, não houve diferença significante na contagem UFC/mL de Candida spp. para ambos os grupos. Para S. mutans, não houve diferença significante entre as soluções $(\mathrm{p}<0,001)$ para o grupo que não realizou a imersão das escovas, enquanto que para o grupo com imersão da escova o Efferdent ${ }^{\circledR}$ e hipoclorito de sódio a $0,2 \%$ mostraram redução na contagem UFC/mL de $S$. mutans quando comparado ao grupo Controle $(\mathrm{p}=0,001)$.

A literatura mostra resultados de efetividade do hipoclorito de sódio em concentrações mais altas e maiores tempos de imersão, como Kulak et al. (1997) que avaliaram uma concentração de 5\% em imersões de 8 horas frente micro-organismos presentes em próteses totais, e mostrou-se efetiva. Em relação à concentração de 0,5\%, Porta et al. (2013) mostraram efetividade frente Candida spp. e micro-organismos totais quando empregada em imersões de 3 minutos após 30, 60 e 90 dias de uso. Salles et al. (2015a), avaliando pacientes com mucosa palatina normal e empregando imersões de 20 minutos, também verificaram efetividade de concentrações a $0,5 \%$ e $0,25 \%$ frente Candida spp., gram negativos e S. mutans, com superioridade da solução a $0,5 \%$. Nossos resultados confirmam a possibilidade do uso de concentrações mais baixas, e em tempo de imersão curto, o que previne a ocorrência de efeitos adversos à resina acrílica.

Em relação à efetividade antimicrobiana dos peróxidos, a literatura não é conclusiva. Panariello et al. (2016) investigaram a eficácia da imersão e escovação frente a biofilme multiespécies (C. albicans, C. glabrata, e S. mutans), no entanto, verificaram que o biofilme foi reduzido significantemente pela escovação ou imersão em ácido peracético a $0,2 \%$, digluconato de clorexidina a $1 \%$ e hipoclorito de sódio a $1 \%$, por apenas 10 segundos, enquanto o Corega Tabs® não demostrou a mesma efetividade. Já Pires et al. (2017) encontraram efeito intermediário para o Corega Tabs ${ }^{\circledR}$, em imersões de 5 e 30 minutos, ao investigarem a eficácia antimicrobiana de diferentes agentes químicos utilizados para a higienização de próteses totais, sendo que, o hipoclorito de sódio a $0,018 \%$, o vinagre e o digluconato de clorexidina a $0,12 \%$ foram considerados produtos adequados para limpeza de próteses dentárias devido ao seu 
potencial de inibição do crescimento bacteriano, semelhante ao hipoclorito de sódio a $1 \%$. Coimbra et al. (2016) encontraram efetividade, in vitro, do peróxido Medical Interpourors® frente a C. albicans (Ca), C. glabrata (Cg), Staphylococcus aureus (Sa), S. mutans (Sm), Enterococcus faecalis (Ef), Escherichia coli (Ec), e Pseudomonas aeruginosa (Pa); enquanto o Efferdent ${ }^{\circledR}$ foi efetivo para $\mathrm{Cg}, \mathrm{Sm}$, Ef, Ec e Pa; e o Corega Tabs® apresentou ação para Sa, Ec e Bacillus subtilis. Tais resultados, foram semelhantes aos encontrados no presente estudo, o qual encontrou efetividade do Efferdent ${ }^{\circledR}$ para os dois micro-organismos testados, Candida spp. e $S$. mutans, mas em biofilme in vivo.

Um fator importante a ser destacado refere-se ao tipo de biofilme avaliado, uma vez que a maior parte dos estudos com soluções de peróxido alcalinos são com biofilme in vitro, de forma que os estudos clínicos randomizados com essa solução são escassos, o que pode interferir na efetividade dessas soluções. Além disso, outro fator determinante para a efetividade dos peróxidos alcalinos está relacionado aos seus componentes químicos. A literatura mostra que os peróxidos alcalinos mais utilizados são Corega Tabs, Polident, Medical Interporous e Steradent; tais higienizadores apresentam alguns ingredientes em comum em sua composição, como o Carbonato de Sódio, Sulfato de Sódio e Bicarbonato de Sódio, porém estão presentes em diferentes concentrações, o que pode, dessa forma, estar relacionado à menor ou maior efetividade de cada produto.

Na literatura há poucos estudos sobre a eficácia da solução de Ricinus communis como higienizadores de próteses totais e o presente estudo encontrou efetividade dessa solução em biofilme in vivo, frente à Candida spp. e S. mutans, o que discorda dos resultados relatados pela literatura em outras concentrações. Uma solução de mamona a $2 \%$ também mostrou efetividade na redução do número de espécies de Candida spp. e S. mutans quando analisadas próteses totais inferiores reembasadas e, utilizando a técnica de hibridização de DNACheckerboard para a análise microbiológica (Segundo et al., 2014). Pinelli et al. (2013) avaliaram um colutório de Ricinus communis a 3,3\% durante 30 dias em pacientes com Estomatite Protética e mostrou efetividade na remissão dos sinais clínicos da patologia. Arruda et al. (2017) utilizaram uma concentração de 8\% como solução auxiliar na higienização de próteses totais por 14 dias e também verificaram melhora clínica da Estomatite Protética, no entanto, a solução de Ricinus communis não foi capaz de reduzir a contagem de Candida spp..

Salles et al. (2015b) em avaliação in vitro mostraram que uma solução a $10 \%$, comparada às soluções de hipoclorito de sódio a $0,50 \%$ e $0,25 \%$, foi capaz de eliminar 
completamente cepas de B. subtilis, porém apresentou ação intermediária para as cepas de $S$. aureus, Pseudomonas aeruginosa, C. albicans, $C$. glabrata e $S$. mutans, além de não apresentar efeito sobre E. faecalis. Uma avaliação in vivo da concentração de $10 \%$ mostrou efetividade frente a $S$. mutans e ação intermediária frente a Candida spp. quando comparada às soluções de hipoclorito de sódio a 0,50\% e 0,25\% (Salles et al., 2015a). Leite et al. (2014) em estudo envolvendo dentifrícios à base de mamona a 2,5 e 10\%, mostraram efetividade de ambos frente às cepas de $S$. mutans, S. aureus e E. faecalis, porém não mostraram ação contra Candida spp. e Escherichia coli. Mordenti, et al. (1982) relataram que o tratamento com o ricinoleato está correlacionado com uma queda significativa da produção de ácido no biofilme, porém, não há na literatura estudos in vivo que confirmem essa hipótese. Os resultados aqui encontrados de efetividade da solução a 6,25\% frente Candida spp. e S. mutans são promissores, uma vez que tais micro-organismos são frequentemente encontrados no biofilme protético, além de estarem relacionados com doenças sistêmicas, como já abordado anteriormente.

Cumpre salientar que tal ação foi similar à ação das soluções de hipoclorito de sódio e peróxido alcalino, podendo ser indicada não apenas para higienização de próteses totais, mas também na higienização de próteses parciais removíveis, nas quais a presença do metal, contraindica a utilização da solução de hipoclorito de sódio; e a solução de peróxido, por ter um valor alto no mercado brasileiro, acaba não sendo utilizada pelos usuários de próteses.

Ao observar as médias de Log (UFC/mL) de Candida spp. e S. mutans das próteses, podemos notar que todos apresentaram ação antimicrobiana, se considerarmos a definição feita pela Agência Nacional de Vigilância Sanitária (2010), de que deve haver redução de 1 Log do número de UFC inicialmente avaliados. Para o Candida spp., ao comparar com o baseline, houve redução de 1,21 Log para o controle; 2,94 Log para o HS 0,2\%; 2,16 Log para o Efferdent ${ }^{\circ}$ e 1,36 Log para RC 6,25\% entre os pacientes que não realizaram a imersão da escova nas soluções avaliadas. Para os que realizaram a imersão das escovas, ocorreu uma redução de 1,2 para o controle; 2,76 Log para HS 0,2\%; 2,7 Log para o Efferdent ${ }^{\circ}$ e 2,27 Log para RC 6,25\%. Para S. mutans, para os pacientes que não realizaram a imersão da escova nas soluções avaliadas em relação ao baseline, a redução de UFC/mL para o controle foi de 1,14 Log; 4,28 Log para o HS 0,2\%; 3,77 Log para o Efferdent® e 2,83 Log para RC 6,25\%; já os entre aqueles que realizaram a imersão das escovas, ocorreu uma redução de 0,87 para o controle; 3,33 Log para HS 0,2\%; 3,27 Log para o Efferdent ${ }^{\circledR}$ e 2,56 Logs para RC 6,25\%. 
É importante discutir o fato de que, apesar de não ter dado diferença estatística, a redução Log para as soluções de hipoclorito de sódio e peróxido alcalino, foram maiores, em todas as avaliações, do que para a solução de Ricinus communis, sendo que diferenças maiores de redução do Log, podem implicar um melhor desempenho clínico dessas soluções. Além disso, pode-se notar que, a solução de hipoclorito de sódio apresentou menores médias de UFC/mL entre os participantes que não realizaram a imersão da escova, para os dois microorganismos testados, enquanto que para as soluções Efferdent ${ }^{\circledR}$ e Ricinus communis a maior redução de UFC/mL ocorreu para o grupo que realizou a imersão das escovas nas soluções, para os dois micro-organismos. Isso pode estar relacionado aos efeitos deletérios da solução do hipoclorito nas cerdas de nylon das escovas, o que promoveu um maior número de ranhuras, e pode ter favorecido o depósito de micro-organismos.

Tal fato, foi observado durante a avaliação qualitativa das imagens obtidas por MEV, de forma que nas imagens após imersão na solução de hipoclorito de sódio, principalmente na imagem com aumento de 3500x, foi possível observar a presença em grande quantidade de defeitos, que não foram observadas nas cerdas das escovas dos pacientes que utilizaram o hipoclorito de sódio, mas não realizaram o protocolo de imersão das escovas. Essa diferença visível entre as cerdas das escovas dos dois grupos não foi observada para as soluções Efferdent ${ }^{\circledR}$ e Ricinus communis. Outro fato importante a ser discutido é que, apesar das escovas terem sido utilizadas por apenas 7 dias, juntamente a cada solução, as imagens mostraram deterioração das mesmas, principalmente na parte superior das cerdas, mesmo para os participantes do grupo controle. Esse resultado é importante uma vez uma maior a deterioração das cerdas das escovas poder ser prejudicial, por facilitar um maior acúmulo de biofilme nas cerdas, que pode ser transferido para as próteses e consequentemente, para a cavidade oral do paciente.

É importante que o paciente faça uso de um método que seja eficaz no controle do biofilme. Uma limitação da presente pesquisa foi a impossibilidade de evitar que os participantes identificassem o peróxido alcalino Efferdent®. Embora estivesse armazenada sem identificação, a sua forma (sachê com pó) e protocolo de utilização eram diferentes das demais soluções, que estavam armazenadas em frascos idênticos e sem identificação.

O estudo foi realizado com período de imersão de 20 minutos, mas é importante que essas soluções também sejam clinicamente avaliadas em imersões de 8 horas, uma vez que tal período é também indicado e empregado por usuários de próteses totais (Shay, 2000; Souza et 
al., 2009; Felton et al., 2011). Além disso, tais estudos devem avaliar essas soluções quanto à efetividade e possíveis alterações nas propriedades dos materiais constituintes da prótese. Em relação à ação antimicrobiana, foi realizada apenas a avaliação frente à Candida spp. e $S$. mutans, sendo importante que estudos futuros envolvam outros micro-organismos presentes no biofilme protético. Em relação ao controle do biofilme, a maioria dos estudos está relacionada a próteses totais, e poucos estudos relatam a eficácia de higienizadores no controle do biofilme in vivo de próteses parciais removíveis (Lucena-Ferreira; Cavalcanti, Cury, 2013) e pelo fato de não ter um consenso quanto a solução ideal para higienização dessas próteses, a Ricinus communis pode ser uma possível solução auxiliar. 


\section{Conclusões}



Com base nas condições experimentais do presente estudo e de acordo com a metodologia empregada, foi possível concluir que:

1) Quanto à eficácia da remoção do biofilme todas as soluções avaliadas foram efetivas, promovendo uma diminuição significativa do biofilme das superfícies das próteses totais;

2) Quanto à ação antimicrobiana as três soluções testadas foram efetivas frente a Candida spp.. Em relação ao $S$. mutans, as soluções de hipoclorito de sódio a 0,2\% e Efferdent foram efetivas, enquanto a solução de Ricinus communis a 6,25\% apresentou ação moderada;

3) Quanto às escovas:

3.1. Não houve diferença entre as soluções na redução de UFC/mL de Candida spp. entre os grupos em relação ao protocolo de imersão;

3.2. Para S. mutans, o Efferdent e hipoclorito de sódio a $0,2 \%$ mostraram redução de UFC/mL para o grupo com imersão da escova;

3.3. A solução de hipoclorito de sódio a $0,2 \%$ promoveu maior deterioração nas cerdas;

4) Considerando as avaliações realizadas, pode-se inferir que as três soluções avaliadas podem ser empregadas como agentes auxiliares de higiene frente ao controle do biofilme de próteses totais. 



\section{Referências Bibliográficas'}

${ }^{1}$ De acordo com o International Committee of Medical Journal Editors, adaptado pela U.S. National Library of Medicine (estilo Vancouver).

Disponível em: http://www.ncbi.nlm.nih.gov/bookshelf/br.fcgi?book=citmed 


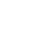


Akpan A, Morgan R. Oral candidiasis. Postgrad Med J. 2002 Aug;78(922):455-9.

Ambjornsen E, Rise J, Haugejorden O. A study of examiner errors associated with measurement of denture plaque. Acta Odontol Scand. 1984 Jun;42(3):183-91.

Agência Nacional de Vigilância Sanitária (ANVISA). Farmacopeia Brasileira, volume 2 \% Brasília: Anvisa, 2010. 546p., 1v/il. 1. Substâncias farmacêuticas químicas, vegetais e biológicas.

Andrade IM, Andrade KM, Pisani MX, Silva-Lovato CH, de Souza RF, Paranhos Hde F. Trial of an experimental castor oil solution for cleaning dentures. Braz Dent J. 2014 JanFeb;25(1):43-7.

Andrade IM, Cruz PC, da Silva CH, de Souza RF, Paranhos Hde F, Candido RC, et al. Effervescent tablets and ultrasonic devices against Candida and mutans streptococci in denture biofilm. Gerodontology. 2011 Dec;28(4):264-70.

Andrade IM, Silva-Lovato CH, de Souza RF, Pisani MX, de Andrade KM, Paranhos Hde F. Trial of experimental toothpastes regarding quality for cleaning dentures. Int J Prosthodont. 2012 Mar-Apr;25(2):157-9.

Andrucioli MC, de Macedo LD, Panzeri H, Lara EH, Paranhos Hde F. Comparison of two cleansing pastes for the removal of biofilm from dentures and palatal lesions in patients with atrophic chronic candidiasis. Braz Dent J. 2004;15(3):220-4.

Arai K, Sumi Y, Uematsu H, Miura H. Association between dental health behavious, mental/physical function and self-feeding ability among the elderly: a cross-sectional survey. Gerodontology. 2003; 20: 78-83.

Arruda CNF. Avaliação do hipoclorito de sódio e solução de mamona (ricinus communis) quanto à eficácia do controle do biofilme de próteses totais e efeitos adversos sobre a resina acrílica termicamente ativada [Dissertação]. Ribeirão Preto: Faculdade de Odontologia de Ribeirão Preto, Universidade de São Paulo; 2014. 
Arruda CNF, Salles MM, Badaró MM, Oliveira VC, Macedo A, Silva-Lovato CH, Paranhos HFO. Effect of sodium hypochlorite and Ricinus communis solutions on control of denture biofilm: A randomized crossover clinical trial. J Prosthet Dent. 2017 Jun;117(6):729734.doi:10.1016/j.prosdent.2016.08.035.

Arruda CNF, Salles MM, Badaró MM, Sorgini DB, Oliveira VC, Macedo AP, Silva-Lovato $\mathrm{CH}$, Paranhos HFO. Evaluation of biofilm removal and adverse effects on acrylic resin by diluted concentrations of sodium hypochlorite and Ricinus communis solutions. Gerodontology. 2018 May 23. doi: 10.1111/ger.12348.

Arruda CNF, Sorgini DB, Oliveira VC, Macedo AP, Silva-Lovato CH, Paranhos HFO. Effects of denture cleansers on heat-polymerized acrylic resin: A five-year-simulated period of use. Braz Dent J. 2015; 26(4):404-408.

Augsburger RH, Elahi JM. Evaluation of seven proprietary denture cleansers. J Prosthet Dent. 1982 Apr;47(4):356-9.

Azevedo NF, Cerca N. Biofilmes: Na Saúde, no Ambiente, na Indústria. Porto, Portugal; 2012.

Badaró MM. Avaliação clínica e laboratorial do efeito de soluções de Hipoclorito de sódio, Cloramina T e Ricinus communis sobre espécies de Candida identificadas no biofilme de próteses totais e palato de indivíduos desdentados totais [Tese]. Ribeirão Preto: Faculdade de Odontologia de Ribeirão Preto, Universidade de São Paulo; 2017.

Badaró MM, Salles MM, Arruda CNF, Oliveira VC, de Souza RF, Paranhos HFO, SilvaLovato CH. In Vitro Analysis of Surface Roughness of Acrylic Resin Exposed to the Combined Hygiene Method of Brushing and Immersion in Ricinus communis and Sodium Hypochlorite. J Prosthodont. 2017;26(6):516-521.

Badaró MM, Salles MM, Leite VMF, Arruda CNF, Oliveira VC, Nascimento C, Souza RF, Paranhos HFO, Silva-Lovato CH. Clinical trial for evaluation of Ricinus communis and sodium hypochlorite as denture cleanser. J Appl Oral Sci. 2016;25(3):324-334. 
Baena-Monroy T, Moreno-Maldonado V, Franco-Martínez F, Aldape-Barrios B, Quindós G, Sánchez-Vargas. Candida albicans, Staphylococcus aureus and Streptococcus mutans colonization in patients wearing dental prosthesis. Med Oral Patol Oral Cir Bucal. 2005;10:E27-9.

Barbeau J, Seguin J, Goulet JP, de Koninck L, Avon SL, Lalonde B, et al. Reassessing the presence of Candida albicans in denture-related stomatitis. Oral Surg Oral Med Oral Pathol Oral Radiol Endod. 2003 Jan;95(1):51-9.

Barnabe W, de Mendonca Neto T, Pimenta FC, Pegoraro LF, Scolaro JM. Efficacy of sodium hypochlorite and coconut soap used as disinfecting agents in the reduction of denture stomatitis, Streptococcus mutans and Candida albicans. J Oral Rehabil. 2004 May;31(5):453-9.

Basman A, Peker I, Akca G, Alkurt MT, Sarikir C, Celik I. Evaluation of toothbrush disinfection via different methods. Brazilian oral research. 2016;30, pii: S180683242016000100203.

Basson NJ, Quick AN, Thomas CJ. Household products as sanitising agents in denture cleasing. J Dent Assoc S Afr. 1992;47(10):437-9.

Bloem TJ, Razzoog ME. An index for assessment of oral health in the edentulous population. Spec Care Dentist. 1982 May-Jun;2(3):121-4.

Boscato N, Radavelli A, Faccio D, Loguercio AD. Biofilm formation of Candida albicans on the surface of a soft denture-lining material. Gerodontology. 2009 Sep;26(3):210-3.

Buergers R, Rosentritt M, Schneider-Brachert W, Behr M, Handel G, Hahnel S. Efficacy of denture disinfection methods in controlling Candida albicans colonization in vitro. Acta Odontol Scand. 2008 Jun;66(3):174-80.

Campos MS, Marchini L, Bernardes LA, Paulino LC, Nobrega FG. Biofilm microbial communities of denture stomatitis. Oral microbiology and immunology. 2008 Oct;23(5):41924. 
Chopde N, Jawale B, Pharande A, Chaudhari L, Hiremath V, Redasani R. Microbial colonization and their relation with potential cofactors in patients with denture stomatitis. The journal of contemporary dental practice. 2012;13(4):456-9.

Coco BJ, Bagg J, Cross LJ, Jose A, Cross J, Ramage G. Mixed Candida albicans and Candida glabrata populations associated with the pathogenesis of denture stomatitis. Oral Microbiol Immunol. 2008 Oct;23(5):377-83.

Coimbra FCT, Salles MM, Oliveira VC, Macedo AP, Silva-Lovato CH, Pagnano VO, Paranhos HFO. Antimicrobial action of complete denture cleansers (alkaline peroxide) against specific microorganisms. Am J Dent. 2016 Jun;29(3):149-53.

Coulthwaite L, Verran J. Potential pathogenic aspects of denture plaque. Br J Biomed Sci. 2007;64(4):180-9.

Council on Dental Materials I, and Equipment. Denture cleansers. J Am Dent Assoc. 1983 Jan;106(1):77-9.

Cruz PC, Andrade IM, Peracini A, Souza-Gugelmin MC, Silva-Lovato CH, de Souza RF, et al. The effectiveness of chemical denture cleansers and ultrasonic device in biofilm removal from complete dentures. J Appl Oral Sci. 2011 Nov-Dec;19(6):668-73.

Dhamande MM, Pakhan AJ, Thombare RU, Ghodpage SL. Evaluation of efficacy of commercial denture cleansing agents to reduce the fungal biofilm activity from heat polymerized denture acrylic resin: An in vitro study. Contemporary clinical dentistry. 2012 Apr;3(2):168-72.

Davi LR, Felipucci DN, de Souza RF, Bezzon OL, Lovato-Silva CH, Pagnano VO, et al. Effect of denture cleansers on metal ion release and surface roughness of denture base materials. Braz Dent J. 2012;23(4):387-93. 
De Paola LG, Minah GE, Elias AS. Evaluation of agentes to reduce microbial growth on dental prostheses of myelosupressed cancer patients. Clinic Prevent Dent. 1984;6(2):9-12.

DiBardino DM, Wunderink RG. Aspiration pneumonia: a review of modern trends. J Crit Care. 2015 Feb;30(1):40-8.

Duyck J, Vandamme K, Muller P, Teughels W. Overnight storage of removable dentures in alkaline peroxide-based tablets affects biofilm mass and composition. $\mathrm{J}$ Dent. 2013;41(12),1281-9.

Efstratiou M, Papaioannou W, Nakou M, Ktenas E, Vrotsos IA, Panis V. Contamination of a toothbrush with antibacterial properties by oral microorganisms. J Dent. 2007;35(4):331-7.

Erickson L. Oral health promotion and prevention for older adults. Dent Clin North Am 1997; 41: 727- 747 .

Felipucci DN, Davi LR, Paranhos HF, Bezzon OL, Silva RF, Pagnano VO. Effect of different cleansers on the surface of removable partial denture. Braz Dent J. 2011a;22(5):392-7.

Felipucci DN, Davi LR, Paranhos HF, Bezzon OL, Silva RF, Barbosa Junior F, et al. Effect of different cleansers on the weight and ion release of removable partial denture: an in vitro study. J Appl Oral Sci. 2011b Oct;19(5):483-7.

Felton D, Cooper L, Duqum I, Minsley G, Guckes A, Haug S, et al. Evidence-based guidelines for the care and maintenance of complete dentures: a publication of the American College of Prosthodontists. J Prosthodont. 2011 Feb;20 Suppl 1:S1-S12.

Fernandes RA, Lovato-Silva CH, Paranhos Hde F, Ito IY. Efficacy of three denture brushes on biofilm removal from complete dentures. J Appl Oral Sci. 2007 Feb;15(1):39-43.

Fernandes FSF, Pereira-Cenci T, da Silva WJ, Filho AP, Straioto FG, Del Bel Cury AA. Efficacy of denture cleansers on Candida spp. biofilm formed on polyamide and polymethyl methacrylate resins. J Prosthet Dent. 2011 Jan;105(1):51-8. 
Ferreira CM, Bonifacio KC, Froner IC, Ito IY. Evaluation of the antimicrobial activity of three irrigating solutions in teeth with pulpal necrosis. Braz Dent J. 1999;10(1):15-21.

Garcia Junior A. Avaliação da eficácia dos desinfetantes químicos na desinfecção de resina acrílica termopolimerizável [dissertação]. Ribeirão Preto: Faculdade de Odontologia de Ribeirão Preto, Universidade de São Paulo; 2002.

Gendreau L, Loewy ZG. Epidemiology and etiology of denture stomatitis. J Prosthodont. 2011 Jun;20(4):251-60.

Gornitsky M, Paradis II, Landaverde G, Malo AM, Velly AM. A clinical and microbiological evaluation of denture cleansers for geriatric patients in long-term care institutions. J Can Dent Assoc. 2002 Jan;68(1):39-45.

Grimoud AM, Lodter JP, Marty N, Andrieu S, Bocquet H, Linas MD, et al. Improved oral hygiene and Candida species colonization level in geriatric patients. Oral Dis. 2005 May;11(3):163-9.

Haghi HR, Asadzadeh N, Sahebalam R, Nakhaei M, Amir JZ. Effect of denture cleansers on color stability and surface roughness of denture base acrylic resin. Indian $\mathrm{J}$ Dent Res. 2015;26(2):163-6.

Harrison Z, Johnson A, Douglas CW. Na in vitro study into the effect of a limited range of denture cleaners on surface roughness and removal of Candida albicans from conventional heat-cured acrylic resin denture base material. J Oral Rehabil. 2004;31(5):460-7.

Hong G, Murata H, Li Y, Sadamori S, Hamada T. Influence of denture cleansers on the color stability of three types of denture base acrylic resin. J Prosthet Dent. 2009 Mar;101(3):205-13.

Hutchins DW, Parker WA. A clinical evaluation of the ability of denture cleaning solutions to remove dental plaque from prosthetic devices. N Y State Dent J. 1973 Jun-Jul;39(6):363-7. 
Imsand M, Janssens JP, Auckenthaler R, Mojon P, Budtz-Jorgensen E. Bronchopneumonia and oral health in hospitalized older patients. A pilot study. Gerodontology. 2002 Dec;19(2):66-72.

Iseri U, Uludamar A, Ozman YK. Effectiveness of diferente cleaning agentes on the adherence of Candida albicans to acrylic denture base resin. Gerodontology. 2011; 28(4): 271-276.

Ito IY, Fröner IC, Mian H, GO C. Castor oil: antimicrobial activity of detergent derived from ricinoleic acid. J Dent Res. 1999;78:344.

Jagger DC, Harrison A. Denture cleansing-the best approach. Br Dent J. 1995;178(11):413-17.

Jose A, Coco BJ, Milligan S, Young B, Lappin DF, Bagg J, Murray C, Ramage G. Reducing the incidence of denture stomatitis: Are denture cleansers sufficient? J Prosthodontics 2010; 19 (4): 252-257.

Keng SB, Lim M. Denture plaque distribution and the effectiveness of a perborate-containing denture cleanser. Quintessence Int. 1996 May;27(5):341-5.

Kulak Y, Arikan A, Albak S, Okar I, Kazazoglu E. Scanning electron microscopic examination of different cleaners: surface contaminant removal from dentures. J Oral Rehabil. 1997 Mar;24(3):209-15.

Kumar MN, Thippeswamy HM, Raghavendra Swamy KN, Guijari AK. Effeicacy of comercial and household denture cleansers against Candida albicans adherent to acrylic denture base resin: an in vitro study. Indian J Dent Res. 2012, 23(1): 39-42.

Lee D, Howlett J, Pratten J, Mordan N, McDonald A, Wilson M, et al. Susceptibility of MRSA biofilms to denture-cleansing agents. FEMS microbiology letters. 2009 Feb;291(2):241-6.

Leite VMF. Avaliação laboratorial de um dentifrício experimental à base de Ricinus communis para limpeza de próteses totais [dissertação] Ribeirão Preto: Faculdade de Odontologia de Ribeirão Preto, Universidade de São Paulo; 2012. 
Leite VM, Pinheiro JB, Pisani MX, Watanabe E, de Souza RF, Paranhos HFO, et al. In vitro antimicrobial activity of an experimental dentifrice based on Ricinus communis. Braz Dent J. 2014 Jul;25(3):191-6.

Li X, Kolltveit KM, Tronstad L, Olsen I. Systemic diseases caused by oral infection. Clin Microbiol Rev. 2000 Oct;13(4):547-58.

Lima EM, Moura JS, Del Bel Cury AA, Garcia RC, Cury JA. Effect of enzymatic and NaOCl treatments on acrylic roughness and on biofilm accumulation. J Oral Rehabil. 2006 May;33(5):356-62.

Lucena-Ferreira SC, Cavalcanti IM, Cury AA. Efficacy of denture cleansers in reducing microbial counts from removable partial dentures: a short-term clinical evaluation. Braz Dent J. 2013;24(4):353-6. doi: 10.1590/01036440201302183.

Lucena-Ferreira SC, Ricomini-Filho AP, Silva WJ, Cury JA, Cury AA. Influence of daily immersion in denture cleanser on multispecies biofilm. Clinical oral investigations. 2014 Dec;18(9):2179-85.

Ma T, Johnson GH, Gordon GE. Effects of chemical disinfectants on the surface characteristics and color of denture resins. J Prosthet Dent. 1997 Feb;77(2):197-204.

Malheiros-Segundo AL. Avaliação clínica e laboratorial de uma solução experimental para hygiene de reembasador resiliente para prótese total [tese]. Ribeirão Preto: Faculdade de Odontologia de Ribeirão Preto, Universidade de São Paulo; 2011.

McNeme SJ, von Gonten AS, Woolsey GD. Effects of laboratory disinfecting agents on color stability of denture acrylic resins. J Prosthet Dent. 1991 Jul;66(1):132-6.

Meneghin MP, Nomelini SM, Sousa-Neto MD, Marchesan MA, Franca SC, dos Santos HS. Morphologic and morphometric analysis of the root canal apical third cleaning after biomechanical preparation using 3.3\% Ricinus communis detergent and $1 \% \mathrm{NaOCl}$ as irrigating solutions. J Appl Oral Sci. 2006 Jun;14(3):178-82. 
Mendham, J.; Denney R.C.; Barnes J.D.; Thomas M.J.K.. Análise Química Quantitativa.

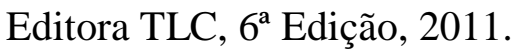

Meriç G, Güvenir M, Süer K. Evaluating the efficiency of humic acid to remove microorganisms from denture base material. Gerodontology. 2016 Sep;33(3):395-401.

Montagner H, Montagner F, Braun KO, Peres PE, Gomes BP. In vitro antifungal action of different substances over microwaved-cured acrylic resins. Journal of applied oral science : revista FOB. 2009 Sep-Oct;17(5):432-5.

Moon A, Powers JM, Kiat-Amnuay. Color stability of denture teeth and acrylic base resin subjected daily to various consumer cleansers. J Esthet Restor Dent. 2014;26(4):247-55.

Moore TC, Smith DE, Kenny GE. Sanitization of dentures by several denture hygiene methods J Prosthet Dent. 1984;52(2):158-63.

Mordenti JJ, Lindstrom RE, Tanzer JM. Activity of sodium ricinoleate against in vitro plaque. J Pharm Sci. 1982 Dec;71(12):1419-21.

Nascimento C, Scarabel TT, Miani PK, Watanabe E, Pedrazzi V. In vitro evaluation of the microbial contamination on new toothbrushes: a preliminary study. Microscopy research and technique. 2012 Jan;75(1):42-5.

Nascimento C, Sorgini MB, Pita MS, Fernandes FH, Calefi PL, Watanabe E, et al. Effectiveness of three antimicrobial mouthrinses on the disinfection of toothbrushes stored in closed containers: a randomized clinical investigation by DNA Checkerboard and Culture. Gerodontology. 2014 Sep;31(3):227-36.

Nelson-Filho P, Pereira MS, De Rossi A, da Silva RA, de Mesquita KS, de Queiroz AM, et al. Children's toothbrush contamination in day-care centers: how to solve this problem? Clinical oral investigations. 2014 Nov;18(8):1969-74. 
Nikawa H, Hamada T, Yamamoto T. Denture plaque--past and recent concerns. J Dent. 1998 May;26(4):299-304.

Nikawa H, Hamada T, Yamashiro H, Kumagai H. A review of in vitro and in vivo methods to evaluate the efficacy of denture cleansers. Int J Prosthodont. 1999 Mar-Apr;12(2):153-9.

Nikawa H, Yamamoto T, Hamada T, Rahardjo MB, Murata H. Commercial denture cleansers - cleansing efficacy against Candida albicans biofilm and compatibility with soft denture-lining materials. Int J Prosthodont. 1995a;8(5):434-44.

Nikawa H, Yamamoto T, Hamada T, Sadamori S, Agrawal S. Cleansing efficacy of commercial denture cleansers: ability to reduce Candida albicans biofilm activity. Int J Prosthodont. $1995 b ; 8(6): 527-534$.

Nishi Y, Seto K, Kamashita Y, Kaji A, Kurono A, Nagaoka E. Survival of microorganisms on complete dentures following ultrasonic cleaning combined with immersion in peroxide-based cleanser solution. Gerodontology. 2014 Sep;31(3):202-9.

O'Donnell LE, Robertson D, Nile CJ, Cross LJ, Riggio M, Sherriff A, et al. The Oral Microbiome of Denture Wearers Is Influenced by Levels of Natural Dentition. PloS one. 2015;10(9):e0137717.

Panariello BH, Izumida FE, Moffa EB, Pavarina AC, Jorge JH, Giampaolo ET. Effect of mechanical toothbrushing combined with different denture cleansers in reducing the viability of a multispecies biofilm on acrylic resins. Am J Dent. 2016 Jun;29(3):154-60.

Panzeri H, Lara EH, Paranhos Hde F, Lovato da Silva CH, de Souza RF, de Souza Gugelmin $\mathrm{MC}$, et al. In vitro and clinical evaluation of specific dentifrices for complete denture hygiene. Gerodontology. 2009 Mar;26(1):26-33. 
Paranhos Hde F, Salles AE, Macedo LD, Silva-Lovato CH, Pagnano VO, Watanabe E. Complete denture biofilm after brushing with specific denture paste, neutral soap and artificial saliva. Braz Dent J. 2013;24(1):47-52.

Paranhos HFO, Silva CHL. Comparative study of methods for the quantification of biofilm on complete dentures. Braz Oral Res. 2004;18(3):215-23.

Paranhos HF, Silva-Lovato CH, de Souza RF, Cruz PC, de Freitas-Pontes KM, Watanabe E, et al. Effect of three methods for cleaning dentures on biofilms formed in vitro on acrylic resin. $\mathrm{J}$ Prosthodont. 2009 Jul;18(5):427-31.

Paranhos HF, Silva-Lovato CH, Souza RF, Cruz PC, Freitas KM, Peracini A. Effects of mechanical and chemical methods on denture biofilm accumulation. J Oral Rehabil. 2007a Aug;34(8):606-12.

Paranhos HFO, Silva-Lovato CH, Venezian GC, Macedo LD, de Souza RF. Distribution of biofilm on internal and external surfaces of upper complete dentures: the effect of hygiene instruction. Gerodontology. 2007b Sep;24(3):162-8.

Pavarina AC, Pizzolitto AC, Machado AL, Vergani CE, Giampaolo ET. An infection control protocol: effectiveness of immersion solutions to reduce the microbial growth on dental prostheses. J Oral Rehabil. 2003 May;30(5):532-6.

Peracini A, Andrade IM, Oliveira VC, Macedo AP, Silva-Lovato, Pagnano VO, Watanabe E, Paranhos HFO. Antimicrobial action and long-term effect of overnight denture cleansers. Am J Dent. 2017.

Peracini A, Regis RR, Souza RF, Pagnano VO, Silva CH, Paranhos HF. Alkaline Peroxides Versus Sodium Hypochlorite for Removing Denture Biofilm: a Crossover Randomized Trial. Braz Dent J. 2016;27(6):700-704.

Pinelli LA, Montandon AA, Corbi SC, Moraes TA, Fais LM. Ricinus communis treatment of denture stomatitis in institutionalised elderly. J Oral Rehabil. 2013 May;40(5):375-80. 
Pinheiro JB, Vomero MP, do Nascimento C, Watanabe E, Paranhos HFO, Coto NP, Dias $\mathrm{RB}$, Oliveira VC, Silva-Lovato $\mathrm{CH}$. Genomic identification of microbial species adhering to maxillofacial prostheses and susceptibility to different hygiene protocols. Biofouling. 2018 Jan;34(1):15-25.

Pires CW, Fraga S, Beck AC, Braun KO, Peres PE. Chemical Methods for Cleaning Conventional Dentures: What is the Best Antimicrobial Option? An In Vitro Study. Oral Health Prev Dent. 2017;15(1):73-77.

Pisani MX, da Silva CH, Paranhos HF, Souza RF, Macedo AP. Evaluation of experimental cleanser solution of Ricinus communis: effect on soft denture liner properties. Gerodontology. 2012b Jun;29(2):e179-85.

Pisani MX, Macedo AP, Paranhos Hde F, Silva CH. Effect of experimental Ricinus communis solution for denture cleaning on the properties of acrylic resin teeth. Braz Dent J. 2012a;23(1):15-21.

Pisani MX, Silva-Lovato CH, Paranhos HFO, Souza RF, Macedo AP. The Effect of Experimental Denture Cleanser Solution Ricinus communis on Acrylic Resin Properties. Materials Researsh. 2010;13(3):369-73.

Pisani MX. Influência de uma solução experimental para higiene de próteses totais nas propriedades físicas e mecênicas de resinas acrílicas, dentes artificiais e reembasadores resilientes [dissertação]. Ribeirão Preto: Universidade de São Paulo, Faculdade de Odontologia de Ribeirão Preto; 2009.

Polyzois GL, Yannikakis SA, Zissis AJ, Demetriou PP. Color changes of denture base materials after disinfection and sterilization immersion. Int J Prosthodont. 1997 Jan-Feb;10(1):83-9.

Porta SRS, Lucena-Ferreira SC, Da Silva WJ, Del Bel Cury AA. Evaluation of sodium hypochlorite as a denture cleanser: a clinical study. Gerodontology. 2013.

Powell GL, Runnells RD, Saxon BA, Whisenant BK. The presence and identification of organisms transmitted to dental laboratories. J Prosthet Dent. 1990;64(2),235-7. 
Przybylowska D, Mierzwinska-Nastalska E, Rubinsztajn R, Chazan R, Rolski D, SwobodaKopec E. Influence of Denture Plaque Biofilm on Oral Mucosal Membrane in Patients with Chronic Obstructive Pulmonary Disease. Adv Exp Med Biol. 2014 Sep 25.

Ramage G, Tomsett K, Wickes BL, López-Ribot JL, Redding SW. Denture stomatitis: A role for Candida biofilms. Oral Sur Oral Med Oral Pathol Oral Radiol Endod. 2004;98(1):53-9.

Rocha MM. Ação antimicrobiana e efeitos adversos de soluções higienizadoras de próteses totais - estudo in vitro [Dissertação]. Ribeirão Preto: Faculdade de Odontologia de Ribeirão Preto, Universidade de São Paulo; 2018.

Rossato MB, Unfer B, May LG, Braun KO. Analysis of the effectiveness of different hygiene procedures used in dental prostheses. Oral Health Prev Dent. 2011;9(3):221-7.

Salles AE, Macedo LD, Fernandes RA, Silva-Lovato CH, Paranhos Hde F. Comparative analysis of biofilm levels in complete upper and lower dentures after brushing associated with specific denture paste and neutral soap. Gerodontology. 2007 Dec;24(4):217-23.

Salles MM, Badaró MM, Arruda CNF, Leite VMF, Silva-Lovato CH, Watanabe E, et al. Antimicrobial activity of complete denture cleanser solutions based on sodium hypochlorite and Ricinus communis - a randomized clinical study. J Appl Oral Sci. 2015a;23(6):637-42.

Salles MM, Oliveira Vde C, Souza RF, Silva CH, Paranhos Hde F. Antimicrobial action of sodium hypochlorite and castor oil solutions for denture cleaning - in vitro evaluation. Braz Oral Res. 2015b;29(1):1-6.

Sato S, Cavalcante MR, Orsi IA, Paranhos HOF, Zaniquelli O. Assessment of flexural strength and color alteration of heat-polymerized acrylic resins after simulated use of denture cleansers. Braz Dent J. 2005;16(2):124-8.

Segundo A de L, Pisani MX, Nascimento C, Souza RF, Paranhos Hde F, Silva-Lovato CH. Clinical trial of an experimental cleaning solution: antibiofilm effect and integrity of a siliconebased denture liner. J Contemp Dent Pract. 2014;15(5):534-42. 
Scannapieco FA. Pneumonia in nonambulatory patients. The role of oral bacteria and oral hygiene. J Am Dent Assoc. 2006 Oct;137 Suppl:21S-5S.

Senpuku H, Sogame A, Inoshita E, Tsuha Y, Miyazaki H, Hanada N. Systemic diseases in association with microbial species in oral biofilm from elderly requiring care. Gerontology. 2003 Sep-Oct;49(5):301-9.

Shay K. Denture hygiene: a review and update. J Contemp Dent Pract. 2000 Feb 15;1(2):2841.

Sheen SR, Harrison A. Assessment of plaque prevention on dentures using an experimental cleanser. J Prosthet Dent. 2000;84(6):594-601.

Silva CHL, Paranhos HFO. Efficacy of biofilm disclosing agent and of three brushes in the control of complete denture cleansing. J Appl Oral Sci. 2006;14(6):454-9.

Silva FC, Kimpara ET, Mancini MN, Balducci I, Jorge AO, Koga-Ito CY. Effectiveness of six different disinfectants on removing five microbial species and effects on the topographic characteristics of acrylic resin. J Prosthodont. 2008 Dec;17(8):627-33.

Silva-Lovato CH, Totti AMG, Paranhos HFO, Totti VG. Evaluation of a computerized method for denture biofilm quantification: inter-examiner reproducibility. J Prosthodont. 2009 Jun;18(4):332-6.

Silva-Lovato $\mathrm{CH}$, Paranhos HFO, Ito IY. Evidenciadores de biofilme em prótese total: avaliação clínica e ação antimicrobiana Pesquisa Odontológica Brasileira. 2002;16(3):270-75.

Silva-Lovato CH, Wever B, Adriaens E, Paranhos Hde F, Watanabe E, Pisani MX, et al. Clinical and antimicrobial efficacy of NitrAdine -based disinfecting cleaning tablets in complete denture wearers. J Appl Oral Sci. 2010 Dec;18(6):560-5. 
Siqueira DCR. Avaliação comparativa in vivo da atividade antimicrobiana do hipoclorito de sódio a $1 \%$, da clorexidina a $2 \%$ e do detergente derivado do óleo de mamona a $10 \%$, utilizados como soluções irrigadoras em endodontia [dissertação] Bauru: Universidade de São Paulo, Faculdade de Odontologia de Bauru; 2005.

Souza RF, Paranhos HFO, Silva-Lovato CH, Abu-Naba'a L, Fedorowicz Z, Gurgan CA. Interventions for cleaning dentures in adults. Cochrane Database Syst Rev. 2009 (4):CD007395.

Stewart OS, Rayner J, Roe F, Rees WM. Biofilm penetration and disinfection efficacy of alkaline hypochlorite and chlorosulfamates. J Appl Microbiol. 2001;91(3):525-32.

Srinivasan M, Gulabani M. A microbiological evaluation of the use of denture cleansers in combination with an oral rinse in complete denture patients. Indian journal of dental research: official publication of Indian Society for Dental Research. 2010 Jul-Sep;21(3):353-6.

Unlu A, Altay OT, Sahmali S. The role of denture cleansers on the whitening of acrylic resins. Int J Prosthodont. 1996 May-Jun;9(3):266-70.

Watkinson AC, McCreight MC, Warnock DW. Prevalence and persistence of different strains of Candida albicans in treatment of denture stomatitis. J Prosthet Dent. 1985 Mar;53(3):365-6.

Webb BC, Thomas CJ, Harty DWS, Willcox MDP. Effectiveness of two methods of denture sterilization. J Oral Rehabil. 1998;25(6):416-23.

Webb BC, Thomas CJ, Whittle T. A 2-year study of Candida-associated denture stomatitis treatment in aged care subjects. Gerodontology. 2005 Sep;22(3):168-76.

Yilmaz H, Aydin C, Bal BT, Õzçelik B. Effects of disinfectants on resilient denture-lining materials contamined with Staphylococcus aureus, Streptococcus aureus, Streptococcus sobrinus, and Candida albicans. Quintessence Int. 2005;36(5):373-81.

Zarnowski R, Westler WM, Lacmbouh GA, Marita JM, Bothe JR, Bernhardt J, et al. Novel entries in a fungal biofilm matrix encyclopedia. mBio. 2014;5(4):e01333-14. 



\section{Apêndices}



$\underline{\text { Apêndice A - Termo de Consentimento Livre e Esclarecido }}$

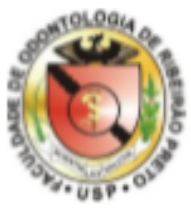

\section{UNIVERSIDADE DE SÃO PAULO FACULDADE DE ODONTOLOGIA DE RIBEIRAO PRETO}

\section{TERMO DE CONSENTIMINTO LIVRE E ESCL.ARECIDO \\ (Item 2 da Resolução 466/2012 - Conselho Nacional de Saúde)}

Convidamos você RG:

a participar da pesquisa "Efetividade do hipoclorito de sódio, peróxido alcalino e vieinus communis no controle do biofilme protético" desenvolvida sob a responsabilidade da Profa. Dra. Helena de Freitas Oliveira Paranhos e com a participação da CD Carolina Noronha Ferraz De Arruda (Pós-graduanda), Profa. Dra. Cláudia Helena Lovato da Silva, CD Marcela Moreira Salles (Pós-graduanda). Após receber todas as explicaçẽes necessárias para a participação na pesquisa, cabe a você decidir de livre e espontânea vontade se quer assinar esse Termo de

Consentimento Livre e Eselarecido com a finalidade de autorizar sua participação na referida pesquisa.

Sendo assim, esclarecemos que:

1. Esta pesquisa é importante para avaliar produtos para higiene de suas dentaduras.

2. O estudo tem por objetivo avaliar alguns produtos liquidos onde as próteses deverão ficar mer gulhadas para a limpeza. Você receberá 4 líquidos diferentes (Solução de Mamona a 2\%, soro fisiológico, solução de Hipoclorito de Sódio a $0,20 \%$ (semelhante a água sanitária que você possui em casa, só que bem mais diluido) e sachê de Efferdente Power Clean Crystals), sabão neutro e uma escova especifiea para escovação de dentaduras.

3. Você deverá escovar suas dentaduras após as refeiçōes utilizando o sabão neutro e a escova. Após a última escovação (depois de jantar), a dentadura deverá ser mergulhada em um copo contendo o produto que você recebeu. A cada 7 dias, os pesquisadores irão lhe dar novos produtos, até que você receba todos os quatro. Em algumas semanas, você não receberá produtos. Quando isso acontecer, a limpeza das suas dentaduras será feita somente com o sabão neutro e a escova. Os pesquisadores entregarão também, as instruções por escrito para the ajudar a compreender melhor o estudo.

4. Para avaliar se o produto está limpando ou não, as dentaduras serã̃o avaliadas, na clínica, fora da boca. Para isso, as dentaduras serão coradas com um produto adequado e depois serão escovadas pelos pesquisadores com escova, pasta e água até que fiquem limpas.

5. Quando os pesquigadores estiverem manipulando suas próteses, estas poderão cair no chão, vindo a quebrar-se. Porém todos os cuidados serão tomados por nós para que isso não ocorra, e caso acontę̧a, serão feitas novas dentaduras imediatamente.

6. Não há previsão de que a pesquisa seja desconfortável ou tenha algum risco para você. Caso ocorra algum dano à sua saúde, em razão da participação na pesquisa, os pesquisadores serão responsáveis por quaisquer despesas e indenizaçōes.

7. Para que a pesquisa possa atingir os objetivos, você deverá comparecer i clinica da Faculdade de Odontologia de Ribeirão Preto, nos dias e horários agendados. Serão 7 semanas. Sempre que posável, seus retornos para a pesquisa serão realizados nos dias em que você estará recebendo tratamento dentário na Faculdade de Odontologia de Ribeiräo Preto. Caso você venha em outro horário, os pesquisadores se comprometem a ressarcir despesas decorrentes da sua participação no estudo, como transporte e alimentação nos dias em que você for chamado para as consultas desta pesquisa.

8. Os pesquisadores se comprometem a prestar assistência integral no decorrer da pesquisa, caso algum dano venha a ocorrer com as dentaduras.

9. A pesquisa não apresenta riscos previsiveis aos participantes, já que se trata de um tratamento baseado apenas na imersão, escovação e coleta de fungos e bactérias da sua dentadura. Você não receberá anestesia, injeçẽes, nem cortes e pontos na boca (sem cirurgia). Essa pesquisa conta apenas com a observação de suas dentaduras.

10. Como beneficio, você receberá toda orientação e treinamento para que mantenham suas próteses limpas e com isso, uma boa saúde bucal. Além disso, você receberá todos os produtos necessários para a limpeza das dentaduras, durante o periodo da pesquisa.

11. Você poderá esclarecer qualquer dúvida da pesquisa antes, durante e após a realização do estudo. 
Apêndice A (continuação) - Termo de Consentimento Livre e Esclarecido

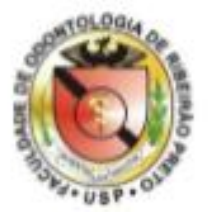

\section{UNIVERSIDADE DE SÃO PAULO \\ FACULDADE DE ODONTOLOGIA DE RIBEIRAO PRETO}

12. Você não terá custos para participar da pesquisa ou para o tratamento envolvido nesta. Você receberá gratuitamente todos os produtos utilizados na pesquisa.

13. Os resultados obtidos serảo divulgados em revistas cientificas e/ou apresentados em congressos. Garantimos a você que na divulgação dos resultados não permitiremos sua identificação como participante. Também, os pesquisadores manterão sigilo sobre sua participaçào na pesquisa.

14. Como sua participação é voluntária, você tem o direito de interrompê-la em qualque momento, sem sofrer penalizações. Caso ocorra algum impedimento sério, que o impossibilite continuar a participar da referida pesquisa, sua desistência não prejudicará o geu atendimento clínico.

15. Qualquer dúvida que vocè tiver, poderá ser esclarecida por um dos pesquisadores envolvidos nesta pesquisa, durante o desenvolvimento do estudo. Caso necessitar poderá entrar em contato com a Profa Dra. Helena de Freitas Oliveira Paranhos, pelo telefone (16) 33154031, ou com qualquer um dos demais pesquigadores. Você também poderá entrar em contato com a secretária do Comitê de Ética em Pesquisa (CEP) da FORP/USP, Marcela Scaltolin Calache pelo telefone (16) 33150493 ou pelo e-mail: cep@forp.uap.br, caso sinta necessidade.

16. Este termo é emitido em duas vias de igual teor, sendo a última página assinada por todos os pesquisadores e por você e as demais rubricadas. Você receberá uma das vias. Você receberá uma das vias e terá o tempo adequado para consultar, se julgar necessário, seus familiares ou pessoas que possam ajudar na tomada de decisão livre e esclarecida. Após estes esclarecimentos, se você, nominado acima, concordar em participar dessa pesquisa, solicito que assine abaixo.

Declaro que li, compreendi e concordo com o presente estudo.
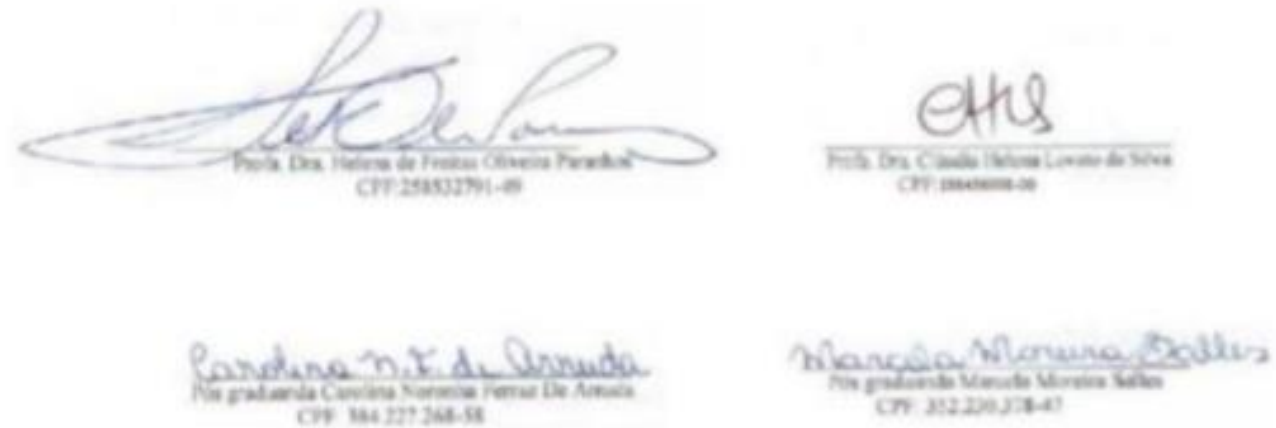

Diante do exposto acima pelos pesquisadores, estou ciente de que não receberei auxilio financeiro para participar deate estudo. Fú informado que não haverá riscos previsiveis durante a aplicação dos tratamentos, mas que posso me manifestar a qualquer momento sobre possiveis desconfortos. Também, que posso fazer perguntas sempre que tiver dúvidas e sair a qualquer momento desse estudo, caso assim seja necessário.

Declaro que li, compreendi e concordo com o presente Termo. 


\section{Apêndice B - Instruções de higiene das próteses totais}

- Instruções de higiene para as soluções controle, hipoclorito de sódio a 0,2\% e Ricinus communis a $6,25 \%$, para os participantes que não realizaram a imersão da escova

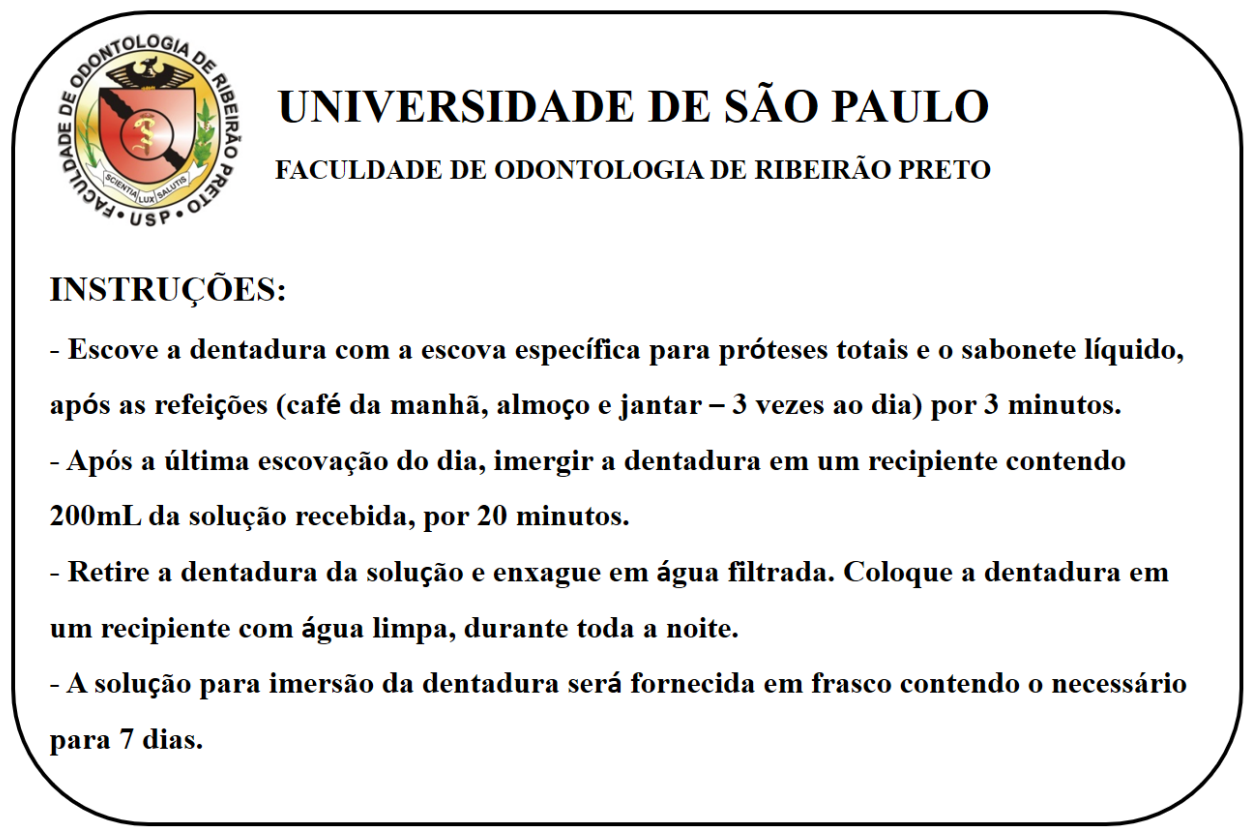

- Instruções de higiene para as soluções controle, hipoclorito de sódio a 0,2\% e Ricinus communis a $6,25 \%$, para os participantes que realizaram a imersão da escova

\section{UNIVERSIDADE DE SÃO PAULO}

FACULDADE DE ODONTOLOGIA DE RIBEIRÃO PRETO

\section{INSTRUÇÕES:}

- Escove a dentadura com a escova específica para próteses totais e o sabonete líquido, após as refeições (café da manhã, almoço e jantar - 3 vezes ao dia) por 3 minutos.

- Após a última escovação do dia, imergir a dentadura e a escova em um recipiente contendo $200 \mathrm{~mL}$ da solução recebida, por 20 minutos.

Retire a dentadura e a escova da solução e enxague em água filtrada. Coloque a dentadura em um recipiente com água limpa, durante toda a noite.

- A solução para imersão da dentadura será fornecida em frasco contendo o necessário para 7 dias. 
- Instruções de higiene para a solução Efferdent, para os participantes que não realizaram a imersão da escova

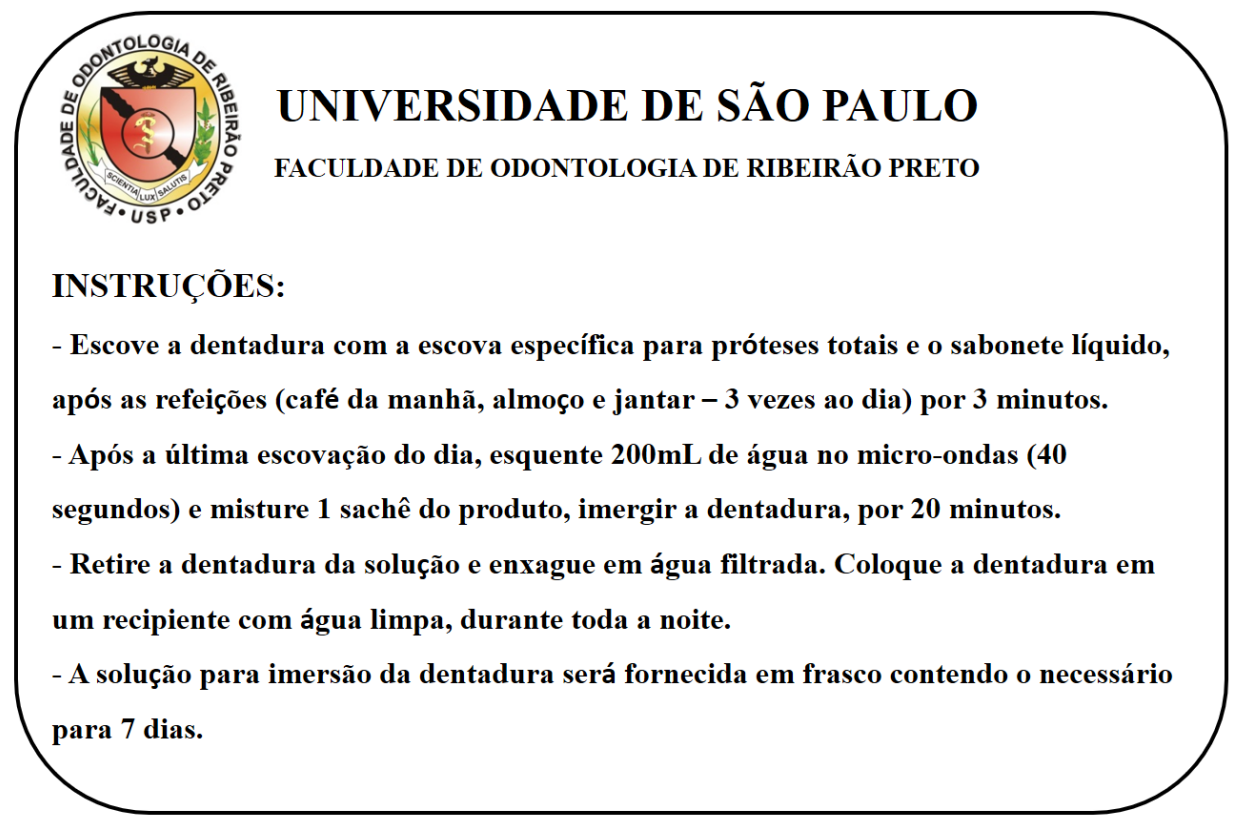

- Instruções de higiene para a solução Efferdent, para os participantes que realizaram a imersão da escova

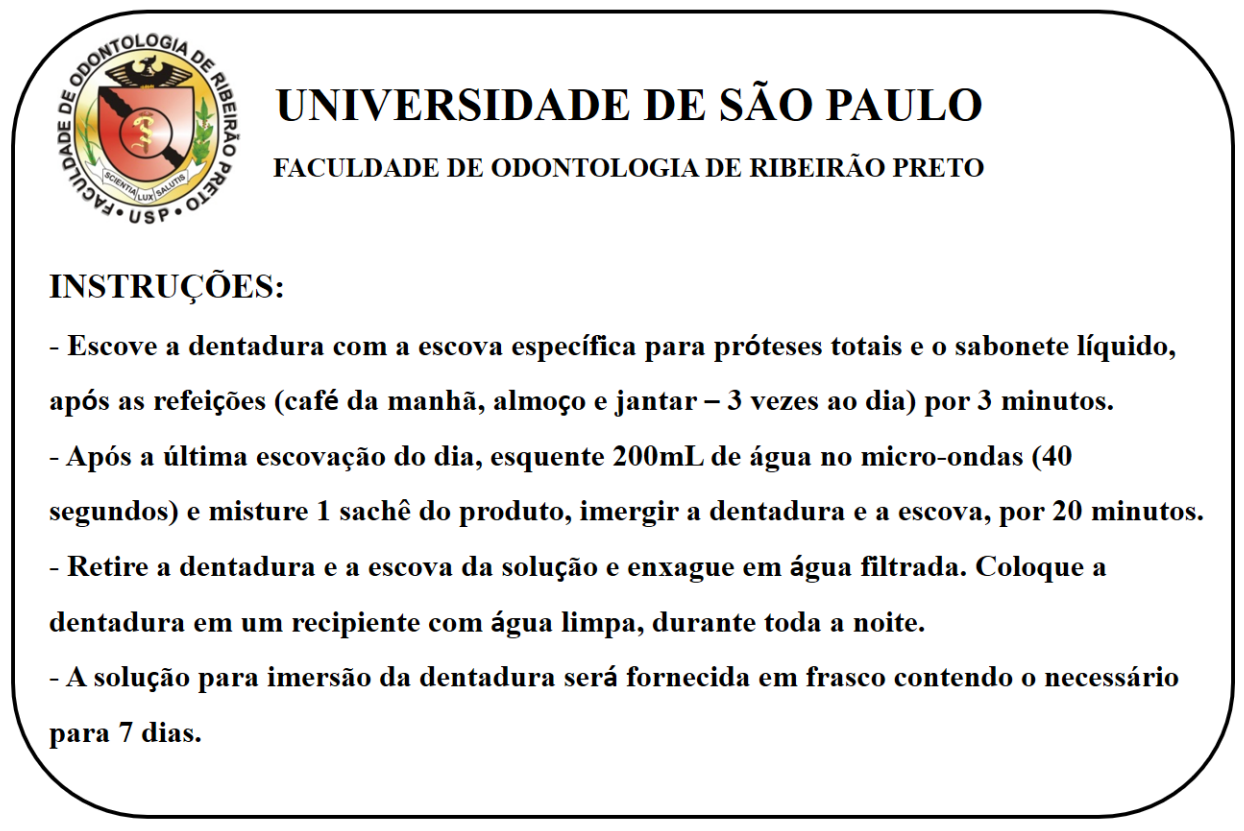




\section{Apêndice C - Solução de hipoclorito de sódio a 0,2\%}

A solução de hipoclorito de sódio foi preparada no Laboratório de Pesquisa em Reabilitação Oral, da Faculdade de Odontologia de Ribeirão Preto, de acordo com Mendham et al., 2011. Inicialmente foi realizada uma reação de iodometria para quantificar o teor de cloro ativo da amostra coletada (Super Candida® - Indústria Anhembi, Osasco, São Paulo, Brasil), para posterior determinação da quantidade necessária para se chegar na concentração de $0,2 \%$.

As reações de titulação foram realizadas com água destilada. Foram realizadas as seguintes etapas:

\section{1- Preparo de $0,1 \mathrm{molL}^{-1}$ de Tiossulfato de Sódio $\left(\mathrm{Na}_{2} \mathrm{~S}_{2} \mathrm{O}_{3}\right)$}

Foram pesados exatamente $2,48 \mathrm{~g}$ de $\mathbf{N a}_{2} \mathbf{S}_{2} \mathbf{O}_{3}$, que foi dissolvido em água destilada e transferido para um balão volumétrico de $100 \mathrm{~mL}$. O volume foi completado, homogeneizado e a massa de $\mathrm{Na}_{2} \mathrm{~S}_{2} \mathrm{O}_{3}$ foi anotada.

\section{2 - Preparo da solução de amido}

Foram pesados $10 \mathrm{~g}$ de amido e adicionado a suspensão a um litro de água, sob agitação em placa aquecedora à $65^{\circ} \mathrm{C}$.

\section{3 - Padronização da solução de $\mathrm{Na}_{2} \mathrm{~S}_{2} \mathrm{O}_{3}$}

Foram pesados $0,10 \mathrm{~g}$ de dicromato de potássio $\left(\mathrm{K}_{2} \mathrm{Cr}_{2} \mathrm{O}_{7}\right)$ e dissolvidos em $50 \mathrm{~mL}$ de água. Foram adicionados $2 \mathrm{~g}$ de iodeto de potássio (KI) e $8 \mathrm{~mL}$ de ácido clorídrico concentrado (HCL). A titulação com tiossulfato de sódio $\left(\mathrm{Na}_{2} \mathrm{~S}_{2} \mathrm{O}_{3}\right)$, foi realizada com agitação, até a mudança da cor castanha da solução para a cor amarela. Foi então adicionado $3 \mathrm{~mL}$ da solução de amido, que é um indicador usado na iodometria uma vez que na presença de iodo adquire 
Volume de tiossulfato consumido: $30,7 \mathrm{~mL}$

$m=\frac{\mathrm{n}}{\mathrm{V}} \longrightarrow 0,09658=\frac{\mathrm{n}}{30,7 \times 10^{-3}} \longrightarrow \mathrm{n}=2,96 \times 10^{-3}$ mols de tiossulfato

Reação de produção do iodo: $\mathrm{H}^{+}+\mathrm{OCl}^{-}+2 \mathrm{I}^{-} \longleftrightarrow \mathrm{Cl}^{-}+\underline{\mathrm{I}}_{2}+\mathrm{H}_{2} \mathrm{O}$

Reação de titulação: $2 \mathrm{~S}_{2} \mathrm{O}_{3}^{2-}+\mathrm{I}_{2} \longleftrightarrow \mathrm{S}_{4} \mathrm{O}_{6}{ }^{2-}+2 \mathrm{I}^{-}$

2 mols de tiossulfato ----- $\underline{1 \mathrm{~mol} \mathrm{de} \text { iodo }}$ e $\quad \underline{1 \mathrm{~mol} \mathrm{de} \mathrm{OCl}}-{ }^{----} 1 \mathrm{~mol} \mathrm{de}_{2}$

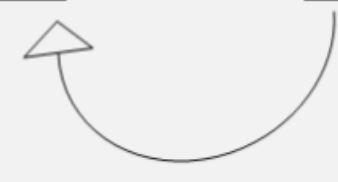

2 mol tiossulfato ----- $1 \mathrm{~mol} \mathrm{de} \mathrm{OCl}^{-}$ $2(158,11 \mathrm{~g})$----- $74,44 \mathrm{~g}$

2 mol tiossulfato ----- $1 \mathrm{~mol}$ hipoclorito $2,96 \times 10^{-3}-----\times$

$\mathrm{x}=1,48 \times 10^{-3}$ mols de hipoclorito

$50 \mathrm{~mL}$----- $1,48 \times 10^{-3}$ mols de hipoclorito

$220 \mathrm{~mL}$---- $\mathrm{x} \quad \mathrm{x}=\mathbf{6 , 5 1 2} \times \mathbf{1 0}^{-3}$ mols de hipoclorito

Em 220 mL há 20 mL da solução de hipoclorito original (Super Candida®):

$20 \mathrm{~mL}$----- $6,512 \times 10^{-3}$ mols de hipoclorito

$1000 \mathrm{~mL}$---- $\mathrm{x} \quad \mathbf{x}=\mathbf{0 , 3 2 5 6} \mathbf{~ m o l} / \mathrm{L}$ de hipoclorito 
$\mathrm{C}=m \times \mathrm{MM} \rightarrow \mathrm{C}=0,3256 \times 74,44 \rightarrow \mathrm{C}=24,23 \mathrm{~g} / \mathrm{L}$

$\mathrm{C}=1000 \mathrm{xdx} \tau \rightarrow \tau=\frac{24,23}{1110} \rightarrow \tau=0,02183$

Dessa forma, a concentração da amostra inicial de hipoclorito de sódio (Super Candida $\left.{ }^{\circledR}\right)$ era de $2,183 \%$. Foi possível então calcular o volume de hipoclorito de sódio necessário para alcançar uma concentração de 0,2\%, a partir da seguinte fórmula:

$\tau_{1} \mathrm{~V}_{1}=\tau_{2} \mathrm{~V}_{2} \rightarrow 2,183 \times \mathrm{V}_{2}=0,20 \times 220 \rightarrow \mathrm{V}_{2}=20,15 \mathrm{~mL}$ de hipoclorito de sódio

Após a diluição a $0,2 \%$, uma nova reação de titulação foi realizada, a fim de confirmar a concentração final. 
Apêndice D - Análise da propriedade de remoção de biofilme

Tabela D. Área total $\left(\mathrm{cm}^{2}\right)$, área de biofilme $\left(\mathrm{cm}^{2}\right)$ e porcentagem de biofilme nas superfícies internas das próteses totais superiores de pacientes com estomatite, no baseline e após uso das soluções.

\begin{tabular}{|c|c|c|c|c|c|c|c|}
\hline Pacientes & Imersão & & Baseline & Controle & HS $0,2 \%$ & Efferdent & RC 6,25\% \\
\hline \multirow{3}{*}{1} & \multirow{3}{*}{ Não } & AT & 18,78 & 19,92 & 18,52 & 19,35 & 31,22 \\
\hline & & $\mathbf{A B}$ & 5,24 & 3,28 & 2,4 & 0,67 & 6,46 \\
\hline & & $\%$ & 27,90 & 16,47 & 12,96 & 3,46 & 20,69 \\
\hline \multirow{3}{*}{2} & \multirow{3}{*}{ Não } & AT & 29,04 & 30,97 & 30,65 & 30,92 & 17,14 \\
\hline & & $\mathbf{A B}$ & 0,78 & 1,17 & 0 & 0,99 & 7,58 \\
\hline & & $\%$ & 2,69 & 3,78 & 0,00 & 3,20 & 0,00 \\
\hline \multirow{3}{*}{3} & \multirow{3}{*}{ Não } & AT & 20,8 & 22,83 & 20,76 & 20,55 & 20,72 \\
\hline & & $A B$ & 4,7 & 8,42 & 0,13 & 0,75 & 0,4 \\
\hline & & $\%$ & 20,56 & 24,10 & 10,52 & 13,95 & 24,24 \\
\hline \multirow{3}{*}{4} & \multirow{3}{*}{ Não } & AT & 21,68 & 22,07 & 21,99 & 21,86 & 22,16 \\
\hline & & $\mathbf{A B}$ & 0,26 & 22,07 & 0 & 0,37 & 0,12 \\
\hline & & $\%$ & 1,26 & 4,21 & 0,00 & 1,82 & 0,56 \\
\hline \multirow{3}{*}{5} & \multirow{3}{*}{ Não } & AT & 20,58 & 19,46 & 20,22 & 20,28 & 21,54 \\
\hline & & $A B$ & 0,26 & 0,82 & 0 & 0,37 & 0,12 \\
\hline & & $\%$ & 1,26 & 4,21 & 0,00 & 1,82 & 0,56 \\
\hline \multirow{3}{*}{6} & \multirow{3}{*}{ Não } & AT & 18,97 & 17,68 & 18,82 & 18,64 & 17,66 \\
\hline & & $\mathbf{A B}$ & 3,9 & 4,26 & 1,98 & 2,6 & 4,28 \\
\hline & & $\%$ & 20,56 & 24,10 & 10,52 & 13,95 & 24,24 \\
\hline \multirow{3}{*}{7} & \multirow{3}{*}{ Não } & AT & 30,24 & 31,05 & 31,14 & 31,27 & 30,35 \\
\hline & & $\mathbf{A B}$ & 16,15 & 11,97 & 0 & 2,86 & 4,88 \\
\hline & & $\%$ & 53,41 & 38,55 & 0,00 & 9,15 & 16,08 \\
\hline \multirow{3}{*}{8} & \multirow{3}{*}{ Não } & AT & 20,12 & 24,1 & 24,33 & 25,29 & 26,02 \\
\hline & & $\mathbf{A B}$ & 4,76 & 7,34 & 11,15 & 2,49 & 8,44 \\
\hline & & $\%$ & 23,66 & 30,46 & 45,83 & 9,85 & 32,44 \\
\hline \multirow{3}{*}{9} & \multirow{3}{*}{ Não } & AT & 21,39 & 29,19 & 27,88 & 25,69 & 27,22 \\
\hline & & $A B$ & 0,92 & 0,25 & 0 & 0,1 & 0 \\
\hline & & $\%$ & 4,30 & 0,86 & 0,00 & 0,39 & 0,00 \\
\hline \multirow{3}{*}{10} & \multirow{3}{*}{ Não } & AT & 19,18 & 18,87 & 20,39 & 18,3 & 19,33 \\
\hline & & $\mathbf{A B}$ & 5,26 & 3,59 & 1,87 & 1,36 & 2,74 \\
\hline & & $\%$ & 27,42 & 19,02 & 9,17 & 7,43 & 14,17 \\
\hline \multirow{3}{*}{11} & \multirow{3}{*}{ Não } & AT & 29,31 & 30,78 & 30,1 & 31,35 & 29,24 \\
\hline & & $\mathbf{A B}$ & 1,1 & 1,38 & 0,82 & 0,67 & 0,89 \\
\hline & & $\%$ & 3,75 & 4,48 & 2,72 & 2,14 & 3,04 \\
\hline \multirow{3}{*}{12} & \multirow{3}{*}{ Não } & AT & 27,91 & 36,7 & 36,36 & 36,77 & 36,6 \\
\hline & & $\mathbf{A B}$ & 2,28 & 6,36 & 0,28 & 0 & 2,09 \\
\hline & & $\%$ & 8,17 & 17,33 & 0,77 & 0,00 & 5,71 \\
\hline
\end{tabular}




\begin{tabular}{|c|c|c|c|c|c|c|c|}
\hline \multirow{3}{*}{13} & \multirow{3}{*}{ Não } & AT & 18,17 & 22,51 & 23,26 & 22,22 & 22,36 \\
\hline & & $\mathbf{A B}$ & 3,48 & 1,89 & 0 & 1,5 & 1,33 \\
\hline & & $\%$ & 19,15 & 8,40 & 0,00 & 6,75 & 5,95 \\
\hline \multirow{3}{*}{14} & \multirow{3}{*}{ Não } & AT & 19,9 & 23,33 & 23,44 & 22,34 & 22,78 \\
\hline & & $\mathbf{A B}$ & 8,31 & 5,24 & 2,64 & 2,73 & 3,51 \\
\hline & & $\%$ & 41,76 & 22,46 & 11,26 & 12,22 & 15,41 \\
\hline \multirow{3}{*}{15} & \multirow{3}{*}{ Não } & AT & 27,51 & 27,26 & 27,34 & 27,69 & 27,81 \\
\hline & & $\mathbf{A B}$ & 1,09 & 1,63 & 0 & 0 & 0,08 \\
\hline & & $\%$ & 3,96 & 5,98 & 0,00 & 0,00 & 0,29 \\
\hline \multirow{3}{*}{16} & \multirow{3}{*}{ Não } & AT & 25,78 & 25,85 & 25,23 & 25,19 & 26,51 \\
\hline & & $\mathbf{A B}$ & 7,88 & 6,39 & 0 & 1,34 & 3,15 \\
\hline & & $\%$ & 30,57 & 24,72 & 0,00 & 5,32 & 11,88 \\
\hline \multirow{3}{*}{17} & \multirow{3}{*}{ Não } & AT & 27,7 & 27,25 & 27,56 & 28,08 & 28,96 \\
\hline & & $\mathbf{A B}$ & 3,13 & 2,77 & 0 & 1,88 & 2,22 \\
\hline & & $\%$ & 11,30 & 10,17 & 0,00 & 6,70 & 7,67 \\
\hline \multirow{3}{*}{18} & \multirow{3}{*}{ Não } & AT & 17,99 & 17,95 & 19,36 & 19,73 & 18,4 \\
\hline & & $\mathbf{A B}$ & 5,18 & 4,43 & 0,22 & 4,62 & 1,91 \\
\hline & & $\%$ & 28,79 & 24,68 & 1,14 & 23,42 & 10,38 \\
\hline \multirow{3}{*}{19} & \multirow{3}{*}{ Não } & AT & 29,01 & 28,19 & 28,77 & 28,51 & 27 \\
\hline & & $\mathbf{A B}$ & 6,8 & 2,01 & 0 & 3,08 & 0,69 \\
\hline & & $\%$ & 23,44 & 7,13 & 0,00 & 10,80 & 2,56 \\
\hline \multirow{3}{*}{20} & \multirow{3}{*}{ Não } & AT & 24,87 & 24 & 24,52 & 23,14 & 23,93 \\
\hline & & $\mathbf{A B}$ & 3,89 & 2,34 & 0,06 & 0,98 & 1,29 \\
\hline & & $\%$ & 15,64 & 9,75 & 0,24 & 4,24 & 5,39 \\
\hline \multirow{3}{*}{21} & \multirow{3}{*}{ Não } & AT & 30,52 & 29,73 & 29,77 & 29,28 & 31,99 \\
\hline & & $\mathbf{A B}$ & 11,64 & 5,12 & 0 & 0,35 & 4,59 \\
\hline & & $\%$ & 38,14 & 17,22 & 0,00 & 1,20 & 14,35 \\
\hline \multirow{3}{*}{22} & \multirow{3}{*}{ Não } & AT & 28,02 & 27,88 & 27,91 & 28,59 & 27,72 \\
\hline & & $\mathbf{A B}$ & 8,43 & 6,7 & 0 & 0,97 & 0,89 \\
\hline & & $\%$ & 30,09 & 24,03 & 0,00 & 3,39 & 3,21 \\
\hline \multirow{3}{*}{23} & \multirow{3}{*}{ Sim } & AT & 22,38 & 20,02 & 20,17 & 20,42 & 19,81 \\
\hline & & $\mathbf{A B}$ & 0,5 & 0,73 & 0 & 0 & 0,41 \\
\hline & & $\%$ & 2,23 & 3,65 & 0,00 & 0,00 & 2,07 \\
\hline \multirow{3}{*}{24} & \multirow{3}{*}{ Sim } & $\mathbf{A T}$ & 29,63 & 28,08 & 29,03 & 27,17 & 26,77 \\
\hline & & $\mathbf{A B}$ & 1,95 & 1,37 & 0,27 & 1,29 & 0,73 \\
\hline & & $\%$ & 6,58 & 4,88 & 0,93 & 4,75 & 2,73 \\
\hline \multirow{3}{*}{25} & \multirow{3}{*}{ Sim } & AT & 24,51 & 22,86 & 23,17 & 23,35 & 24,38 \\
\hline & & $\mathbf{A B}$ & 3,67 & 3,68 & 0 & 0,47 & 1,18 \\
\hline & & $\%$ & 9,62 & 17,28 & 0,00 & 8,36 & 5,09 \\
\hline
\end{tabular}




\begin{tabular}{|c|c|c|c|c|c|c|c|}
\hline \multirow{3}{*}{26} & \multirow{3}{*}{ Sim } & AT & 26 & 24,6 & 24,72 & 26,21 & 24,75 \\
\hline & & $\mathbf{A B}$ & 2,5 & 4,25 & 0 & 2,19 & 1,26 \\
\hline & & $\%$ & 9,62 & 17,28 & 0,00 & 8,36 & 5,09 \\
\hline \multirow{3}{*}{27} & \multirow{3}{*}{ Sim } & AT & 24,56 & 23,03 & 24,57 & 24,64 & 23,88 \\
\hline & & $\mathbf{A B}$ & 2,59 & 1,92 & 2,06 & 1,15 & 2,46 \\
\hline & & $\%$ & 10,55 & 8,34 & 8,38 & 4,67 & 10,30 \\
\hline \multirow{3}{*}{28} & \multirow[b]{3}{*}{ Sim } & AT & 29,86 & 30,93 & 29,64 & 27,95 & 28,03 \\
\hline & & $\mathbf{A B}$ & 5,4 & 4,87 & 1,59 & 2,26 & 2,62 \\
\hline & & $\%$ & 18,08 & 15,75 & 5,36 & 8,09 & 9,35 \\
\hline \multirow{3}{*}{29} & \multirow[b]{3}{*}{ Sim } & AT & 21,71 & 26,22 & 25,99 & 23,56 & 25,51 \\
\hline & & $\mathbf{A B}$ & 14,6 & 2,62 & 7,15 & 3,24 & 1,63 \\
\hline & & $\%$ & 67,25 & 9,99 & 27,51 & 13,75 & 6,39 \\
\hline \multirow{3}{*}{30} & \multirow[b]{3}{*}{ Sim } & AT & 22,02 & 28,5 & 29,62 & 28,32 & 29,35 \\
\hline & & $\mathbf{A B}$ & 2,76 & 0,87 & 0,44 & 0,82 & 0,66 \\
\hline & & $\%$ & 12,53 & 3,05 & 1,49 & 2,90 & 2,25 \\
\hline \multirow{3}{*}{31} & \multirow{3}{*}{ Sim } & AT & 22,1 & 28,63 & 27,43 & 28,3 & 27,48 \\
\hline & & $\mathbf{A B}$ & 3,31 & 1,71 & 0,05 & 0,18 & 0,89 \\
\hline & & $\%$ & 14,98 & 5,97 & 0,18 & 0,64 & 3,24 \\
\hline \multirow{3}{*}{32} & \multirow[b]{3}{*}{ Sim } & AT & 32,46 & 35,92 & 35,66 & 35,07 & 33,04 \\
\hline & & $\mathbf{A B}$ & 4,5 & 3,9 & 1,6 & 2,06 & 1,89 \\
\hline & & $\%$ & 13,86 & 10,86 & 4,49 & 5,87 & 5,72 \\
\hline \multirow{3}{*}{33} & \multirow[b]{3}{*}{ Sim } & AT & 20,23 & 23,56 & 25,22 & 25,48 & 25,13 \\
\hline & & $\mathbf{A B}$ & 5,02 & 3,59 & 1,66 & 3,11 & 1,71 \\
\hline & & $\%$ & 24,81 & 15,24 & 6,58 & 12,21 & 6,80 \\
\hline \multirow{3}{*}{34} & \multirow[b]{3}{*}{ Sim } & AT & 17,64 & 24,14 & 22,17 & 21,37 & 20,76 \\
\hline & & $\mathbf{A B}$ & 8,39 & 10,71 & 2,76 & 9,69 & 9,77 \\
\hline & & $\%$ & 47,56 & 44,37 & 12,45 & 45,34 & 47,06 \\
\hline \multirow{3}{*}{35} & \multirow[b]{3}{*}{ Sim } & AT & 22,7 & 29,22 & 28,46 & 29,39 & 27,76 \\
\hline & & $\mathbf{A B}$ & 3,99 & 2,48 & 0,19 & 1,2 & 1,28 \\
\hline & & $\%$ & 17,58 & 8,49 & 0,67 & 4,08 & 4,61 \\
\hline \multirow{3}{*}{36} & \multirow[b]{3}{*}{ Sim } & AT & 21,85 & 28,58 & 28,72 & 28,24 & 28,07 \\
\hline & & $\mathbf{A B}$ & 2 & 3,48 & 2,32 & 3,06 & 2,42 \\
\hline & & $\%$ & 9,15 & 12,18 & 8,08 & 10,84 & 8,62 \\
\hline \multirow{3}{*}{37} & \multirow{3}{*}{ Sim } & AT & 23,71 & 27,96 & 31,15 & 29,45 & 29,38 \\
\hline & & $\mathbf{A B}$ & 6,87 & 5,42 & 5,3 & 3,79 & 4,36 \\
\hline & & $\%$ & 28,98 & 19,38 & 17,01 & 12,87 & 14,84 \\
\hline \multirow{3}{*}{38} & \multirow{3}{*}{ Sim } & $\mathbf{A T}$ & 26,58 & 25,63 & 25,15 & 25,6 & 26,74 \\
\hline & & $\mathbf{A B}$ & 16,49 & 12,71 & 2,13 & 2,66 & 2,78 \\
\hline & & $\%$ & 62,04 & 49,59 & 8,47 & 10,39 & 10,40 \\
\hline
\end{tabular}




\begin{tabular}{|c|c|c|c|c|c|c|c|}
\hline \multirow{3}{*}{39} & \multirow{3}{*}{ Sim } & AT & 26,76 & 26,62 & 25,18 & 25,88 & 25,83 \\
\hline & & $\mathbf{A B}$ & 2,65 & 2,02 & 1,52 & 1,73 & 1,66 \\
\hline & & $\%$ & 9,90 & 7,59 & 6,04 & 6,68 & 6,43 \\
\hline \multirow{3}{*}{40} & \multirow{3}{*}{ Sim } & AT & 25,22 & 26,04 & 26,74 & 25,96 & 26,11 \\
\hline & & $\mathbf{A B}$ & 11,07 & 9,88 & 5,58 & 8,9 & 8,82 \\
\hline & & $\%$ & 43,89 & 37,94 & 20,87 & 34,28 & 33,78 \\
\hline \multirow{3}{*}{41} & \multirow{3}{*}{ Sim } & AT & 20,51 & 19,62 & 19,67 & 19,53 & 19,63 \\
\hline & & $\mathbf{A B}$ & 7,8 & 5,93 & 4,2 & 4,14 & 4,5 \\
\hline & & $\%$ & 38,03 & 30,22 & 21,35 & 21,20 & 22,92 \\
\hline \multirow{3}{*}{42} & \multirow{3}{*}{ Sim } & AT & 20,58 & 21,79 & 21,08 & 21,95 & 21,76 \\
\hline & & $\mathbf{A B}$ & 9,06 & 7,3 & 3,77 & 4,56 & 4,68 \\
\hline & & $\%$ & 44,02 & 33,50 & 17,88 & 20,77 & 21,51 \\
\hline \multirow{3}{*}{43} & \multirow{3}{*}{ Sim } & AT & 27,71 & 27,73 & 28,43 & 27,22 & 28,67 \\
\hline & & $\mathbf{A B}$ & 10,09 & 8,13 & 6,39 & 6,57 & 5,6 \\
\hline & & $\%$ & 36,41 & 29,32 & 22,48 & 24,14 & 19,53 \\
\hline \multirow{3}{*}{44} & \multirow{3}{*}{ Sim } & AT & 30,77 & 30,75 & 30,67 & 30,54 & 31,59 \\
\hline & & $\mathbf{A B}$ & 7,77 & 5,49 & 0 & 0,99 & 0,95 \\
\hline & & $\%$ & 25,25 & 17,85 & 0,00 & 3,24 & 3,01 \\
\hline \multirow{3}{*}{45} & \multirow{3}{*}{ Sim } & AT & 28,83 & 28,96 & 28,2 & 30,16 & 28,61 \\
\hline & & $\mathbf{A B}$ & 18,23 & 14,92 & 1,75 & 3,43 & 12,01 \\
\hline & & $\%$ & 63,23 & 51,52 & 6,21 & 11,37 & 41,98 \\
\hline
\end{tabular}

HS: Hipoclorito de Sódio; RC: Ricinus communis. 
Apêndice E - Análise da ação antimicrobiana das próteses

Tabela E1. Total de UFC/mL, em $\log (\mathrm{UFC} / \mathrm{mL}+1)$, de Candida spp. da prótese.

\begin{tabular}{|c|c|c|c|c|c|c|}
\hline Pacientes & Imersão & Baseline & Controle & HS 0,2\% & Efferdent & RC 6,25\% \\
\hline 1 & Não & 0 & 240 & 18600 & 0 & 1320 \\
\hline 2 & Não & 8600 & 7860 & 0 & 44400 & 2160 \\
\hline 3 & Não & 20800 & 1800 & 0 & 0 & 0 \\
\hline 4 & Não & 0 & 0 & 0 & 0 & 10000 \\
\hline 5 & Não & 20 & 60 & 0 & 0 & 0 \\
\hline 6 & Não & 200 & 0 & 0 & 0 & 0 \\
\hline 7 & Não & 56000 & 200 & 0 & 0 & 20 \\
\hline 8 & Não & 21000 & 100000 & 234000 & 206000 & 16800 \\
\hline 9 & Não & 184000 & 20000 & 0 & 38000 & 0 \\
\hline 10 & Não & 9600 & 2200 & 388 & 640 & 0 \\
\hline 11 & Não & 1200 & 760 & 0 & 0 & 0 \\
\hline 12 & Não & 370000 & 284000 & 0 & 0 & 80000 \\
\hline 13 & Não & 70000 & 120000 & 0 & 0 & 32000 \\
\hline 14 & Não & 2040000 & 520000 & 120 & 2200 & 300000 \\
\hline 15 & Não & 8000 & 8000 & 0 & 0 & 6800 \\
\hline 16 & Não & 408000 & 0 & 0 & 2740000 & 132000 \\
\hline 17 & Não & 158000 & 280 & 20 & 280 & 32200 \\
\hline 18 & Não & 340 & 0 & 20 & 0 & 0 \\
\hline 19 & Não & 34000 & 0 & 0 & 2900 & 128000 \\
\hline 20 & Não & 12300 & 0 & 0 & 0 & 0 \\
\hline 21 & Não & 436000 & 60 & 0 & 600 & 320000 \\
\hline 22 & Não & 0 & 240 & 18600 & 0 & 1320 \\
\hline 23 & Sim & 420 & 0 & 0 & 0 & 0 \\
\hline 24 & Sim & 1120 & 20 & 0 & 0 & 0 \\
\hline 25 & Sim & 1440 & 0 & 0 & 0 & 0 \\
\hline 26 & Sim & 960 & 0 & 0 & 0 & 0 \\
\hline 27 & Sim & 460 & 400 & 0 & 0 & 0 \\
\hline 28 & Sim & 20 & 0 & 0 & 0 & 0 \\
\hline 29 & Sim & 160000 & 50000 & 0 & 4000 & 2540 \\
\hline 30 & Sim & 11000 & 47000 & 0 & 2880 & 2280 \\
\hline 31 & Sim & 310 & 88 & 0 & 0 & 0 \\
\hline 32 & Sim & 200 & 110 & 0 & 0 & 0 \\
\hline 33 & Sim & 34000 & 23000 & 0 & 0 & 1600 \\
\hline 34 & Sim & 250000 & 228000 & 24800 & 122000 & 20800 \\
\hline 35 & Sim & 9400 & 24800 & 0 & 0 & 0 \\
\hline 36 & Sim & 34600 & 900 & 320 & 140 & 400 \\
\hline
\end{tabular}




$\begin{array}{lcccccc}\mathbf{3 7} & \text { Sim } & 32000 & 27800 & 7000 & 17200 & 16200 \\ \mathbf{3 8} & \text { Sim } & 460000 & 0 & 0 & 0 & 1040 \\ \mathbf{3 9} & \text { Sim } & 10600 & 10200 & 19000 & 0 & 0 \\ \mathbf{4 0} & \text { Sim } & 800 & 15800 & 0 & 820 & 780 \\ \mathbf{4 1} & \text { Sim } & 640000 & 96000 & 760 & 60 & 600 \\ \mathbf{4 2} & \text { Sim } & 120 & 0 & 20 & 0 & 0 \\ \mathbf{4 3} & \text { Sim } & 178000 & 0 & 540 & 0 & 0 \\ \mathbf{4 4} & \text { Sim } & 1320000 & 31000 & 0 & 0 & 3360 \\ \mathbf{4 5} & \text { Sim } & 27000 & 78000 & 3560 & 4800 & 3000\end{array}$

HS: Hipoclorito de Sódio; RC: Ricinus communis.

Tabela E2. Total de UFC/mL, em $\log (\mathrm{UFC} / \mathrm{mL}+1)$, de $S$. mutans da prótese.

\begin{tabular}{ccccccc}
\hline Pacientes & Imersão & Baseline & Controle & HS 0,2 \% & Efferdent & RC 6,25\% \\
\hline $\mathbf{1}$ & Não & 240 & 0 & 0 & 0 & 0 \\
$\mathbf{2}$ & Não & 80 & 160 & 0 & 0 & 0 \\
$\mathbf{3}$ & Não & 2000 & 0 & 0 & 0 & 0 \\
$\mathbf{4}$ & Não & 0 & 0 & 0 & 0 & 0 \\
$\mathbf{5}$ & Não & 0 & 0 & 0 & 0 & 0 \\
$\mathbf{6}$ & Não & 2040000 & 12000 & 0 & 0 & 1600 \\
$\mathbf{7}$ & Não & 3040000 & 6800 & 0 & 0 & 0 \\
$\mathbf{8}$ & Não & 3800 & 0 & 0 & 0 & 100 \\
$\mathbf{9}$ & Não & 360000 & 10200 & 0 & 940 & 0 \\
$\mathbf{1 0}$ & Não & 45000 & 54000 & 480 & 460 & 10200 \\
$\mathbf{1 1}$ & Não & 3920000 & 128000 & 0 & 0 & 0 \\
$\mathbf{1 2}$ & Não & 276000 & 264000 & 0 & 0 & 83400 \\
$\mathbf{1 3}$ & Não & 720000 & 208000 & 0 & 800 & 560000 \\
$\mathbf{1 4}$ & Não & 20440000 & 1400000 & 0 & 0 & 0 \\
$\mathbf{1 5}$ & Não & 296000 & 2400 & 0 & 0 & 0 \\
$\mathbf{1 6}$ & Não & 6740000 & 860000 & 0 & 0 & 132000 \\
$\mathbf{1 7}$ & Não & 180000 & 1080000 & 0 & 140 & 0 \\
$\mathbf{1 8}$ & Não & 1160 & 2980 & 140 & 0 & 5440 \\
$\mathbf{1 9}$ & Não & 4400000 & 960 & 120 & 3360000 & 1840000 \\
$\mathbf{2 0}$ & Não & 860 & 112 & 0 & 0 & 880 \\
$\mathbf{2 1}$ & Não & 1080000 & 14420000 & 20 & 140 & 120 \\
$\mathbf{2 2}$ & Não & 3920000 & 208000 & 0 & 0 & 0 \\
$\mathbf{2 3}$ & Sim & 280 & 0 & 0 & 40 & 0 \\
$\mathbf{2 4}$ & Sim & 60 & 0 & 0 & 0 & 20 \\
$\mathbf{2 5}$ & Sim & 210000 & 1200 & 0 & 20 & 0 \\
$\mathbf{2 6}$ & Sim & 426000 & 2000 & 0 & 0 & 0 \\
$\mathbf{2 7}$ & Sim & 760 & 420 & 0 & 0 & 0
\end{tabular}




\begin{tabular}{lcccccc}
$\mathbf{2 8}$ & Sim & 460 & 0 & 0 & 0 & 0 \\
$\mathbf{2 9}$ & Sim & 64000000 & 5100000 & 0 & 0 & 0 \\
$\mathbf{3 0}$ & Sim & 0 & 24000 & 0 & 38000 & 1120 \\
$\mathbf{3 1}$ & Sim & 0 & 400 & 20 & 0 & 0 \\
$\mathbf{3 2}$ & Sim & 31800 & 12400 & 0 & 220000 & 960 \\
$\mathbf{3 3}$ & Sim & 334000 & 5200000 & 0 & 0 & 6400 \\
$\mathbf{3 4}$ & Sim & 28320000 & 3600000 & 380000 & 1624000 & 2500000 \\
$\mathbf{3 5}$ & Sim & 1020000 & 3920000 & 480 & 0 & 200 \\
$\mathbf{3 6}$ & Sim & 148000 & 11600 & 0 & 0 & 40000 \\
$\mathbf{3 7}$ & Sim & 22220000 & 450000 & 24800 & 58400 & 20400 \\
$\mathbf{3 8}$ & Sim & 1300000 & 0 & 0 & 0 & 2800 \\
$\mathbf{3 9}$ & Sim & 13800 & 4400 & 0 & 20 & 0 \\
$\mathbf{4 0}$ & Sim & 124000 & 4200 & 32000 & 0 & 0 \\
$\mathbf{4 1}$ & Sim & 29920000 & 9480000 & 13420000 & 1490000 & 1180000 \\
$\mathbf{4 2}$ & Sim & 592000 & 126000 & 120 & 20 & 8200 \\
$\mathbf{4 3}$ & Sim & 5500000 & 174000 & 120 & 0 & 200 \\
$\mathbf{4 4}$ & Sim & 2000 & 120 & 0 & 0 & 0 \\
$\mathbf{4 5}$ & Sim & 5980000 & 7200000 & 4160 & 140 & 2960000 \\
\hline
\end{tabular}

HS: Hipoclorito de Sódio; RC: Ricinus communis. 
Apêndice F - Análise da ação antimicrobiana das escovas

Tabela F1. Total de UFC/mL, em log (UFC/mL+1), de Candida spp. da escova.

\begin{tabular}{|c|c|c|c|c|c|}
\hline Pacientes & Imersão & Controle & HS $0,2 \%$ & Efferdent & RC 6,25\% \\
\hline 1 & Não & 0 & 0 & 640 & 0 \\
\hline 2 & Não & 0 & 200 & 0 & 120 \\
\hline 3 & Não & 860 & 20 & 200 & 20 \\
\hline 4 & Não & 1040 & 0 & 0 & 20 \\
\hline 5 & Não & 0 & 0 & 0 & 140 \\
\hline 6 & Não & 0 & 0 & 200 & 0 \\
\hline 7 & Não & 60 & 0 & 0 & 20 \\
\hline 8 & Não & 0 & 0 & 0 & 60 \\
\hline 9 & Não & 20 & 0 & 0 & 0 \\
\hline 10 & Não & 0 & 680 & 0 & 0 \\
\hline 11 & Não & 0 & 0 & 20 & 0 \\
\hline 12 & Não & 21400 & 40 & 0 & 20 \\
\hline 13 & Não & 100 & 0 & 0 & 80 \\
\hline 14 & Não & 19000 & 0 & 100 & 32200 \\
\hline 15 & Não & 200 & 0 & 0 & 0 \\
\hline 16 & Não & 16200 & 20 & 100 & 2920 \\
\hline 17 & Não & 740 & 180 & 240 & 100 \\
\hline 18 & Não & 0 & 0 & 0 & 0 \\
\hline 19 & Não & 0 & 80 & 80 & 420 \\
\hline 20 & Não & 0 & 0 & 100 & 0 \\
\hline 21 & Não & 0 & 60 & 20 & 154000 \\
\hline 22 & Não & 1880 & 40 & 240 & 280 \\
\hline 23 & Sim & 0 & 140 & 0 & 60 \\
\hline 24 & Sim & 0 & 0 & 0 & 0 \\
\hline 25 & Sim & 0 & 0 & 0 & 0 \\
\hline 26 & Sim & 0 & 20 & 0 & 0 \\
\hline 27 & Sim & 0 & 0 & 0 & 0 \\
\hline 28 & Sim & 0 & 0 & 0 & 40 \\
\hline 29 & Sim & 0 & 20 & 140 & 0 \\
\hline 30 & Sim & 4200 & 0 & 4820 & 47000 \\
\hline 31 & Sim & 0 & 0 & 0 & 0 \\
\hline 32 & Sim & 0 & 0 & 0 & 0 \\
\hline 33 & Sim & 80 & 0 & 0 & 3720 \\
\hline 34 & Sim & 1180 & 780 & 40 & 1040000 \\
\hline 35 & Sim & 0 & 40 & 0 & 0 \\
\hline 36 & Sim & 0 & 20 & 0 & 0 \\
\hline
\end{tabular}




\begin{tabular}{cccccc}
$\mathbf{3 7}$ & Sim & 4000 & 0 & 0 & 280 \\
$\mathbf{3 8}$ & Sim & 0 & 140 & 0 & 0 \\
$\mathbf{3 9}$ & Sim & 80000 & 20 & 20 & 20 \\
$\mathbf{4 0}$ & Sim & 15800 & 0 & 0 & 0 \\
$\mathbf{4 1}$ & Sim & 0 & 0 & 20 & 16000 \\
$\mathbf{4 2}$ & Sim & 30000 & 0 & 0 & 0 \\
$\mathbf{4 3}$ & Sim & 0 & 60 & 0 & 0 \\
$\mathbf{4 4}$ & Sim & 640 & 0 & 0 & 300 \\
$\mathbf{4 5}$ & Sim & 160 & 0 & 3580 & 2860 \\
\hline
\end{tabular}

HS: Hipoclorito de Sódio; RC: Ricinus communis.

Tabela F2. Total de UFC/mL, em $\log (\mathrm{UFC} / \mathrm{mL}+1)$, de $S$. mutans da escova.

\begin{tabular}{cccccc}
\hline Pacientes & Imersão & Controle & HS 0,2\% & Efferdent & RC 6,25\% \\
\hline $\mathbf{1}$ & Não & 0 & 0 & 0 & 0 \\
$\mathbf{2}$ & Não & 80 & 0 & 0 & 0 \\
$\mathbf{3}$ & Não & 0 & 0 & 0 & 0 \\
$\mathbf{4}$ & Não & 0 & 0 & 0 & 0 \\
$\mathbf{5}$ & Não & 0 & 0 & 0 & 0 \\
$\mathbf{6}$ & Não & 440 & 0 & 0 & 60 \\
$\mathbf{7}$ & Não & 2600 & 0 & 0 & 0 \\
$\mathbf{8}$ & Não & 0 & 0 & 0 & 1140 \\
$\mathbf{9}$ & Não & 20 & 0 & 0 & 0 \\
$\mathbf{1 0}$ & Não & 100 & 1540 & 0 & 0 \\
$\mathbf{1 1}$ & Não & 1400 & 20 & 160 & 0 \\
$\mathbf{1 2}$ & Não & 6400 & 0 & 0 & 660 \\
$\mathbf{1 3}$ & Não & 0 & 0 & 80 & 60 \\
$\mathbf{1 4}$ & Não & 0 & 100 & 400 & 0 \\
$\mathbf{1 5}$ & Não & 280 & 840 & 0 & 0 \\
$\mathbf{1 6}$ & Não & 49400 & 0 & 0 & 0 \\
$\mathbf{1 7}$ & Não & 0 & 0 & 1360 & 0 \\
$\mathbf{1 8}$ & Não & 0 & 0 & 0 & 0 \\
$\mathbf{1 9}$ & Não & 0 & 0 & 0 & 80 \\
$\mathbf{2 0}$ & Não & 0 & 0 & 98000 & 16600 \\
$\mathbf{2 1}$ & Não & 0 & 20 & 0 & 1140000 \\
$\mathbf{2 2}$ & Não & 1600 & 0 & 0 & 0 \\
$\mathbf{2 3}$ & Sim & 80 & 0 & 20 & 40 \\
$\mathbf{2 4}$ & Sim & 40 & 0 & 0 & 0 \\
$\mathbf{2 5}$ & Sim & 840 & 0 & 0 & 0 \\
$\mathbf{2 6}$ & Sim & 120 & 0 & 0 & 0 \\
$\mathbf{2 7}$ & Sim & 40 & 0 & 0 & 0 \\
& & & 0 & 0 \\
\end{tabular}




\begin{tabular}{|c|c|c|c|c|c|}
\hline 28 & Sim & 0 & 0 & 0 & 0 \\
\hline 29 & Sim & 112000 & 0 & 0 & 0 \\
\hline 30 & Sim & 1440 & 0 & 17800 & 11200 \\
\hline 31 & Sim & 120 & 20 & 0 & 0 \\
\hline 32 & Sim & 12400 & 0 & 1180 & 584000 \\
\hline 33 & Sim & 40800 & 0 & 0 & 80 \\
\hline 34 & Sim & 120 & 0 & 100 & 2500000 \\
\hline 35 & Sim & 320 & 480 & 0 & 0 \\
\hline 36 & Sim & 340 & 0 & 0 & 100 \\
\hline 37 & Sim & 200 & 98000 & 0 & 234000 \\
\hline 38 & Sim & 0 & 0 & 0 & 0 \\
\hline 39 & Sim & 14800 & 0 & 0 & 0 \\
\hline 40 & Sim & 0 & 940 & 0 & 0 \\
\hline 41 & Sim & 40 & 1340 & 24800 & 160 \\
\hline 42 & Sim & 160 & 0 & 0 & 0 \\
\hline 43 & Sim & 2320 & 0 & 40 & 160 \\
\hline 44 & Sim & 80 & 0 & 0 & 0 \\
\hline 45 & Sim & 660 & 0 & 1060 & 174000 \\
\hline
\end{tabular}

HS: Hipoclorito de Sódio; RC: Ricinus communis. 
Anexos 

ANEXO A - Comitê de ética (número de processo e aprovação).

\section{FACULDADE DE ODONTOLOGIA DE RIBEIRÃO PRETO/FORP/ USP}

\section{PARECER CONSUBSTANCIADO DO CEP}

DADOS DO PROJETO DE PESQUISA

Título da Pesquisa: Efetividade de soluções higienizadoras no controle do biofilme protético Pesquisador: Helena de Freitas Oliveira Paranhos

Área Temática:

Versão: 1

CAAE: 48725015.6 .0000 .5419

Instituição Proponente: Universidade de Sao Paulo

Patrocinador Principal: Financiamento Próprio

DADOS DO PARECER

Número do Parecer: 1.253 .849

Apresentação do Projeto:

O Projeto está bem detalhado, especialmente quanto à literatura pertinente ao assunto e à metodologia a ser utilizads.

Objetivo da Pesquisa:

O objetivo deste estudo será avaliar, in vivo, o uso de soluções higienizadoras de próteses totais do tipo imersäo à base de hipoclorito alcalino a $0,20 \%$ e peróxido alcalino em pó e solução de Ricinus communis a $2 \%$, quanto 'capacidade da remoção do biofilme e ação antimicrobiana in vivo frente diferentes microorganismos

Avaliação dos Riscos e Benefícios:

Nåo existem riscos diretos aos participantes da pesquisa, apenas a possibilidade de dano às próteses, o qual será reparado pelas pesquisadoras.

Todos os materiais a serem utilizados pelos participantes serăo custeados pela pesquisa, bem como sugs vindas à FORP-USP em horários fora do atendimento normal, caso necessário.

Comentários e Consideraçôes sobre a Pesquisa:

Pesquisa relevante e de baixo risco aos participantes da pesquisa.

Espera-se importante contribuição ao conhecimento referente ao assunto, com benefícios futuros à saúde das pessoas.

Endereço: Averida do Café sirñ

Bairro: Monte Alngre

UF: $S P$

M

CEP: 14.040 .904

Telefone: (16)3315-0493 Fax: (16)3315-4102 E-mall: ceperforp.usp. br 
ANEXO A (Continuação) - Comitê de ética (número de processo e aprovação).

\section{FACULDADE DE \\ ODONTOLOGIA DE RIBEIRÃO PRETO/ FORP/ USP

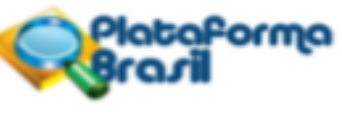

Cortinuaçbo do Parecer: 1.253.649

Considerações sobre os Termos de apresentação obrigatória:

Todos os documentos estão adequados.

Recomendações:

Conclusões ou Pendências e Lista de Inadequações:

Projeto adequado, com parecer favorável à sua aprovaçäo.

Considerações Finais a critério do CEP:

Conforme deliberado pelo CEP em sua $184^{a}$ Sessão, realizada em 30/09/2015.

Este parecer foi elaborado baseado nos documentos abaixo relacionados:

\begin{tabular}{|c|c|c|c|c|}
\hline Tipo Documento & Arquivo & Postagem & Autor & Situaçăo \\
\hline $\begin{array}{l}\text { Informações Básicas } \\
\text { do Projeto }\end{array}$ & $\begin{array}{l}\text { PB_INFORMAÇOEES_BÁSICAS_DO_P } \\
\text { ROJETO 561177.pdf }\end{array}$ & $\begin{array}{c}26 / 08 / 2015 \\
19: 54: 18 \\
\end{array}$ & & Aceito \\
\hline $\begin{array}{l}\text { TCLE / Termos de } \\
\text { Assentimento / } \\
\text { Justificativa de } \\
\text { Ausência }\end{array}$ & TCLE.pdf & $\begin{array}{c}26 / 08 / 2015 \\
19: 53: 50\end{array}$ & $\begin{array}{l}\text { Helena de Freitas } \\
\text { Oliveira Paranhos }\end{array}$ & Aceito \\
\hline $\begin{array}{l}\text { Projeto Detalhado / } \\
\text { Brochura } \\
\text { Investigador }\end{array}$ & PROJETO.pdf & $\begin{array}{c}26 / 08 / 2015 \\
19: 11: 36\end{array}$ & $\begin{array}{l}\text { Helena de Freitas } \\
\text { Oliveira Paranhos }\end{array}$ & Aceito \\
\hline $\begin{array}{l}\text { Declaração de } \\
\text { Instituição e } \\
\text { Infraestrutura }\end{array}$ & $\begin{array}{l}\text { Autorizacao_infra_estrutura_mariotaba.p } \\
\text { df }\end{array}$ & $\begin{array}{c}26 / 08 / 2015 \\
18: 52: 47\end{array}$ & $\begin{array}{l}\text { Helena de Freitas } \\
\text { Oliveira Paranhos }\end{array}$ & Aceito \\
\hline $\begin{array}{l}\text { Declaração de } \\
\text { Instituição e } \\
\text { Infraestrutura }\end{array}$ & Autorizacao_Infraestrutura.pdf & $\begin{array}{c}26 / 08 / 2015 \\
18: 50: 50\end{array}$ & $\begin{array}{l}\text { Helena de Freitas } \\
\text { Oliveira Paranhos }\end{array}$ & Aceito \\
\hline Folha de Rosto & FOLHA DE ROSTRO.pdf & $\begin{array}{c}17 / 08 / 2015 \\
13: 12-31 \\
\end{array}$ & & Aceito \\
\hline Outros & Declaração paciente.pdf & $\begin{array}{c}10 / 08 / 2015 \\
11: 41: 04\end{array}$ & & Aceito \\
\hline
\end{tabular}

Situação do Parecer:

Aprovado

Necessita Apreciação da CONEP:

Năo

Telefone: (16)3315-0493 Fax: (16)3315-4102 E-mall: cep@forp.usp.br 
ANEXO A (Continuação) - Comitê de ética (número de processo e aprovação).

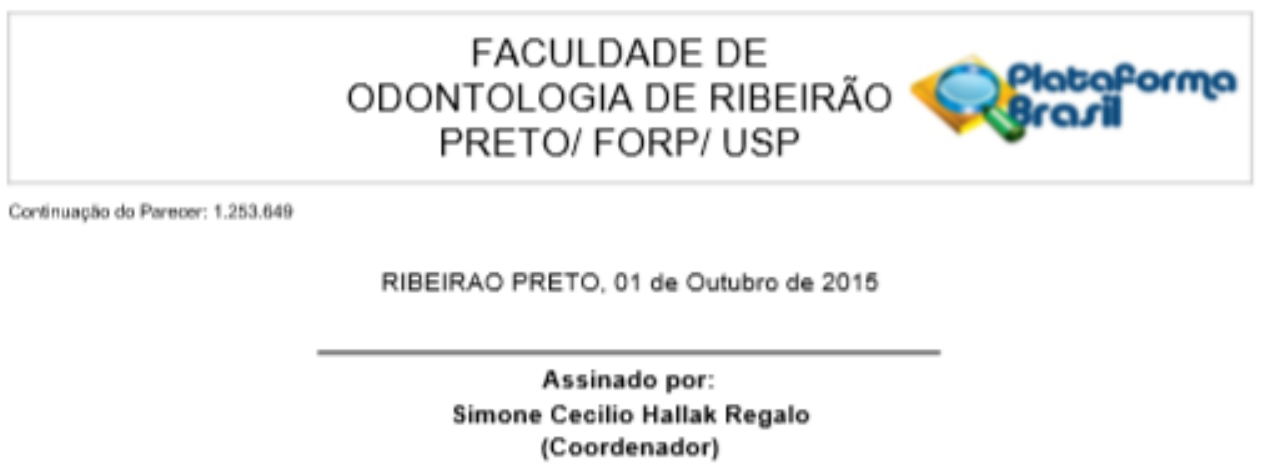

\footnotetext{
Endereço: Averida do Cálé sirn

Bairro: Monte Alegre

CEP: $14.040-904$

UF: SP MUniciplo: RIBEIRAO PRETO
} 